\title{
Survey of Photochemical and Rate Data for Twenty-eight \\ Reactions of Interest in Atmospheric Chemistry
}

\author{
R. F. Hampson, Editor
}

W. Braun, R. L. Brown, D. Garvin, J. T. Herron

R. E. Huie, M. J. Kurylo, A. H. Laufer, J. D. McKinley

H. Okabe, M. D. Scheer, W. Tsang

Physical Chemistry Division, National Bureau of Standards, Washington, D.C. 20234

and

\section{H. Stedman}

Department of Atmospheric Oceanic Science, University of Michigan, Ann Arbor, Michigan 48104

Photochemical and rate data have been evaluated for 28 gas phase reactions of interest for the chemistry of the stratosphere. The results are presented on data sheets, one per reaction. For each reaction, the available data are summarized. Where possible there is given a preferred value for the rate constant or, for the photochemical reactions, preferred values for primary quantum yields and optical absorption coefficients.

Key words: Atmospheric chemistry; chemical kinetics; data evaluation; gas phase reactions; optical absorption coefficients; photochemistry; quantum yields; rate constants.

\section{Contents}

Page

Summary of Evaluated Rate Data 268

Summary of Evaluated Photochemical Data..... 268

1. Introduction........................................ 269

2. Evaluation of Data................................ 269

3. Description of Data Sheets ....................... 269

Acknowledgment ................................... 271

References........................................ 271

4. Data Sheets......................................... 272

4.1. $\mathrm{H}+\mathrm{HNO} \rightarrow \mathrm{H}_{2}+\mathrm{NO} \ldots \ldots \ldots \ldots \ldots \ldots \ldots . \ldots . \ldots . \ldots 272$

4.2. $\mathrm{H}+\mathrm{HNO}_{2} \rightarrow$ Products..................... 272

4.3. $\mathrm{H}+\mathrm{HNO}_{3} \rightarrow$ Products..................... 273

4.4. $\mathrm{H}+\mathrm{H}_{2} \mathrm{O}_{2} \rightarrow$ Products...................... 273

4.5. $\mathrm{H}+\mathrm{NO}_{2} \rightarrow \mathrm{HO}+\mathrm{NO} \ldots \ldots \ldots \ldots \ldots \ldots \ldots \ldots . . . \ldots 274$

4.6. $\mathrm{H}+\mathrm{O}_{3} \rightarrow \mathrm{HO}+\mathrm{O}_{2} \ldots \ldots \ldots \ldots \ldots \ldots \ldots \ldots . \ldots . \ldots \ldots$

4.7. $\mathrm{HNO}+\mathrm{HO} \rightarrow \mathrm{H}_{2} \mathrm{O}+\mathrm{NO} \ldots \ldots \ldots \ldots \ldots . . . . . . .276$

4.8. $\mathrm{HNO}_{2}+\mathrm{HO} \rightarrow \mathrm{H}_{2} \mathrm{O}+\mathrm{NO}_{2} \ldots \ldots \ldots \ldots \ldots . . \ldots 276$

4.9. $\mathrm{HNO}_{2}+\mathrm{O} \rightarrow \mathrm{HO}+\mathrm{NO}_{2} \ldots \ldots \ldots \ldots \ldots \ldots . . . . . . .277$

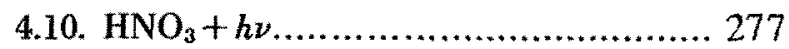

4.11. $\mathrm{HNO}_{3}+\mathrm{HO} \rightarrow \mathrm{H}_{2} \mathrm{O}+\mathrm{NO}_{3} \ldots \ldots \ldots \ldots \ldots . . \ldots 279$

4.12. $\mathrm{HNO}_{3}+\mathrm{O} \rightarrow \mathrm{HO}+\mathrm{NO}_{3} \ldots \ldots \ldots \ldots \ldots \ldots .280$

4.13. $\mathrm{HO}+\mathrm{H}_{2} \mathrm{O}_{2} \rightarrow \mathrm{HO}_{2}+\mathrm{H}_{2} \mathrm{O} \ldots \ldots \ldots \ldots \ldots . .280$

4.14. $\mathrm{HO}+\mathrm{O}_{3} \rightarrow$ Products..................... 282

Copyright (c) 1973 by the U.S. Secretary of Commerce on behalf of the Unated States. This copyright will be asigned to the American luatiute of Phytic and the American Chemical Society, to whom all requests reganding reproduction thand be addressed.
4.15. $\mathrm{HO}_{2}+\mathrm{HO}_{2} \rightarrow \mathrm{H}_{2} \mathrm{O}_{2}+\mathrm{O}_{2} \ldots \ldots \ldots \ldots \ldots \ldots . .285$

4.16. $\mathrm{H}_{2} \mathrm{O}+\mathrm{NO}+\mathrm{NO}_{2} \rightarrow 2 \mathrm{HNO}_{2} \ldots \ldots \ldots \ldots . . .286$

4.17. $\mathrm{H}_{2} \mathrm{O}+\mathrm{N}_{2} \mathrm{O}_{5} \rightarrow 2 \mathrm{HNO}_{3} \ldots \ldots \ldots \ldots \ldots \ldots . \ldots 287$

4.18. $\mathrm{H}_{2} \mathrm{O}+\mathrm{O}\left({ }^{1} D\right) \rightarrow 2 \mathrm{HO} \ldots \ldots \ldots \ldots \ldots \ldots . . . . . . . . . .288$

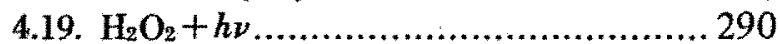

4.20. $\mathrm{H}_{2} \mathrm{O}_{2}+\mathrm{NO} \rightarrow$ Products ..................... 291

4.21. $\mathrm{NO}+\mathrm{O}_{3} \rightarrow \mathrm{NO}_{2}+\mathrm{O}_{2} \ldots \ldots \ldots \ldots \ldots \ldots \ldots . . \ldots 292$

4.22. $\mathrm{NO}_{2}+\mathrm{O}_{3} \rightarrow \mathrm{NO}_{3}+\mathrm{O}_{2} \ldots \ldots \ldots \ldots \ldots \ldots \ldots . . \ldots . \ldots . \ldots . \ldots 29$

4.23. $\mathrm{N}_{2} \mathrm{O}+\mathrm{O}\left({ }^{1} D\right) \rightarrow$ Products ................... 294

4.24. $\mathrm{O}\left({ }^{3} \mathrm{P}\right)+\mathrm{O}_{3} \rightarrow 2 \mathrm{O}_{2} \ldots \ldots \ldots \ldots \ldots \ldots \ldots \ldots . .296$

4.25. $\mathrm{O}_{2}\left({ }^{1} \Delta\right)+\mathrm{M} \rightarrow \mathrm{O}_{2}+\mathrm{M} \ldots \ldots \ldots \ldots \ldots \ldots \ldots . . . . . . . . . . .300$

4.26. $\mathrm{O}_{2}\left({ }^{1} \mathrm{\Sigma}\right)+\mathrm{M} \rightarrow \mathrm{O}_{2}+\mathrm{M} \ldots \ldots \ldots \ldots \ldots \ldots \ldots . . . \ldots \ldots 1$

4.27. $\mathrm{O}_{3}+h \nu$ (visible)........................... 302

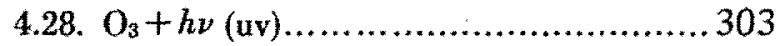

Notes Added in Proof............................... 307

Appendix:

Conversion Tables:

Equivalent Second Order Rate Constants. 309

Equivalent Third Order Rate Constants... 309

Conversion Factors for Units of Molec. ular Energy ................................... 310

Units of Optical Absorption Coefficients... 310

Conversion Factors for Units of Optical Absorption Coefficients...................... 311 
HAMPSON, ET AL.

Summary of Evaluated Rate Data

\begin{tabular}{|c|c|c|c|c|}
\hline \multicolumn{2}{|c|}{ Reaction } & \multirow{2}{*}{$\begin{array}{l}\text { Rate constant } k\left(\mathrm{~cm}^{3} \text { molecule }{ }^{-1} \mathrm{~s}^{-1}\right) \\
>5 \times 10^{-14} \\
7 \times 10^{-12 *}\end{array}$} & \multirow{2}{*}{$\begin{array}{c}\text { Temperature } \\
\text { range }(\mathrm{K})\end{array}$} & \multirow{2}{*}{ 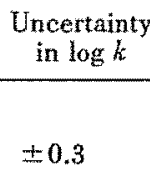 } \\
\hline $\mathrm{H}+\mathrm{HNO}$ & $\rightarrow \mathrm{H}_{2}+\mathrm{NO}$ & & & \\
\hline $\mathrm{H}+\mathrm{HNO}_{2}$ & $\rightarrow$ Products & No recommendation & & \\
\hline $\mathrm{H}+\mathrm{HNO}_{3}$ & $\rightarrow$ Products & $<1 \times 10^{m-13}$ & 300 & \\
\hline $\mathrm{H}+\mathrm{H}_{2} \mathrm{O}_{2}$ & $\begin{aligned} \rightarrow & \mathrm{H}_{2}+\mathrm{HO}_{2} \\
& \mathrm{H}_{2} \mathrm{O}+\mathrm{HO}\end{aligned}$ & $\begin{array}{l}2.8 \times 10^{-12} \exp (-1900 / T) \\
\text { No recommendation }\end{array}$ & $300-800$ & \pm 0.3 \\
\hline $\mathrm{H}+\mathrm{NO}_{\mathrm{s}}$ & $\rightarrow \mathrm{HO}+\mathrm{NO}$ & $4.8 \times 10^{-11}$ & 300 & \pm 0.1 \\
\hline $\mathrm{H}+\mathrm{O}_{3}$ & $\rightarrow \mathrm{HO}+\mathrm{O}_{2}$ & $2.6 \times 10^{-11}$ & 300 & \pm 0.1 \\
\hline $\mathrm{HNO}+\mathrm{HO}$ & $\rightarrow \mathrm{H}_{2} \mathrm{O}+\mathrm{NO}$ & $7 \times 10^{-51 *}$ & $1600-2100$ & \pm 0.7 \\
\hline $\mathrm{HNO}_{2}+\mathrm{HO}$ & $\rightarrow \mathrm{H}_{2} \mathrm{O}+\mathrm{NO}_{2}$ & No recommendation* & & \\
\hline $\mathrm{HNO}_{2}+\mathrm{O}$ & $\rightarrow \mathrm{HO}+\mathrm{NO}_{2}$ & No recommendation & & \\
\hline $\mathrm{HNO}_{3}+\mathrm{HO}$ & $\rightarrow \mathrm{H}_{2} \mathrm{O}+\mathrm{NO}_{3}$ & $6 \times 10^{-13} \exp (-400 / T) *$ & $300-650$ & \pm 0.5 \\
\hline $\mathrm{HNO}_{3}+\mathrm{O}$ & $\rightarrow \mathrm{HO}+\mathrm{NO}_{3}$ & $<1.5 \times 10^{-14}$ & 300 & \\
\hline $\mathrm{HO}+\mathrm{H}_{2} \mathrm{O}_{3}$ & $\rightarrow \mathrm{HO}_{2}+\mathrm{H}_{2} \mathrm{O}$ & $1.7 \times 10^{-11} \exp (-910 / T)$ & $300-800$ & \pm 0.2 \\
\hline $\mathrm{HO}+\mathrm{O}_{3}$ & $\rightarrow \mathrm{HO}_{2}+\mathrm{O}_{2}$ & $1.6 \times 10^{-12} \exp (-1000 / T)^{*}$ & $220-450$ & \pm 0.3 \\
\hline $\mathrm{HO}_{2}+\mathrm{HO}_{2}$ & $\rightarrow \mathrm{H}_{2} \mathrm{O}_{2}+\mathrm{O}_{2}$ & $3 \times 10^{-11} \exp (-500 / T)(a)^{*}$ & $300-1000$ & $\pm 0.3(\mathrm{~b})$ \\
\hline $\mathrm{H}_{2} \mathrm{O}+\mathrm{NO}+\mathrm{N}$ & $\rightarrow 2 \mathrm{HNO}_{2}$ & $<1.1 \times 10^{-55}(c)^{*}$ & 300 & . \\
\hline $\mathrm{H}_{2} \mathrm{O}+\mathrm{N}_{2} \mathrm{O}_{5}$ & $\rightarrow 2 \mathrm{HNO}_{3}$ & $\because<1 \times 10^{-20 *}$ & 300 & 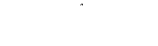 \\
\hline $\mathrm{H}_{2} \mathrm{O}+\mathrm{O}\left({ }^{1} D\right)$ & $\rightarrow 2 \mathrm{HO}$ & $3.5 \times 10^{-10 *}$ & 300 & \pm 0.1 \\
\hline $\mathrm{H}_{2} \mathrm{O}_{2}+\mathrm{NO}$ & $\rightarrow \mathrm{HO}+\mathrm{HNO}_{2}$ & $\begin{aligned}< & 5 \times 10^{-20 *} \\
= & 2 \times 10^{-20}\end{aligned}$ & $\begin{array}{l}300 \\
550\end{array}$ & \\
\hline $\mathrm{NO}+\mathrm{O}_{3}$ & $\rightarrow \mathrm{NO}_{2}+\mathrm{O}_{2}$ & $9 \times 10^{-13} \exp (-1200 / T)$ & $198-330$ & \pm 0.11 \\
\hline $\mathrm{NO}_{2}+\mathrm{O}_{3}$ & $\rightarrow \mathrm{NO}_{3}+\mathrm{O}_{3}$ & $5 \times 10^{-17 *}$ & 298 & \pm 0.2 \\
\hline $\mathrm{N}_{2} \mathrm{O}+\mathrm{O}\left({ }^{\circ} D\right)$ & $\begin{array}{l}\rightarrow \mathrm{N}_{2}+\mathrm{O}_{2} \\
\rightarrow 2 \mathrm{NO}\end{array}$ & $\begin{array}{l}1.1 \times 10^{-10 *} \\
1.2 \times 10^{-10 *}\end{array}$ & $\begin{array}{l}300 \\
300\end{array}$ & $\begin{array}{l} \pm 0.1 \\
\pm 0.1\end{array}$ \\
\hline $\mathrm{O}+\mathrm{O}_{3}$ & $\rightarrow 2 \mathrm{O}_{2}$ & $1.9 \times 10^{-11} \exp (-2300 / T) *$ & $200-1000$ & $\begin{array}{l} \pm 0.1 \\
\pm 0.1\end{array}$ \\
\hline $\mathrm{O}_{2}\left({ }^{\mathrm{I}} \Delta\right)+\mathrm{M}$ & $\rightarrow \mathrm{O}_{2}+\mathrm{M}$ & $\begin{aligned} & 2.2(T / 300)^{0,8} \times 10^{-18}\left(\mathrm{M}=\mathrm{O}_{2}\right) \\
<2 \times 10^{-20} & \left(\mathrm{M}=\mathrm{N}_{2}\right)\end{aligned}$ & $\begin{array}{c}285-322 \\
300\end{array}$ & \pm 0.1 \\
\hline $\mathrm{O}_{2}(\mathrm{~L})+\mathrm{M}$ & $\rightarrow \mathrm{O}_{2}+\mathrm{M}$ & $\begin{array}{l}\left.1.5 \times 10^{-16} \mathrm{M}=\mathrm{O}_{2}\right) \\
2.0 \times 10^{-15}\left(\mathrm{M}=\mathrm{N}_{2}\right) \\
4 \times 10^{-12}\left(\mathrm{M}=\mathrm{H}_{2} \mathrm{O}\right)\end{array}$ & $\begin{array}{l}300 \\
300 \\
300\end{array}$ & $\begin{array}{l} \pm 0.12 \\
\pm 0.1 \\
\pm 0.18\end{array}$ \\
\hline
\end{tabular}

(a) $-d\left[\mathrm{HO}_{2}\right] / d t=2 k\left[\mathrm{HO}_{2}\right]^{2}$

(b) Error in $\log k$ increases to \pm 1 at $1000 \mathrm{~K}$. :

(c) $-d\left[\mathrm{NO}_{2}\right] / d t=k[\mathrm{NO}]\left[\mathrm{NO}_{2}\right]\left[\mathrm{H}_{2} \mathrm{O}\right]^{2}$. Value of $k$ is for a surface reaction. This is adopted as the upper limit for the gas phase rate constant.

*Changed from value recommended in NBS Reports 10692 (Jan. 1972) and 10828 (April 1972).

Summary of Evaluated Photochemical Data

\begin{tabular}{|c|c|c|c|}
\hline Reaction & $\begin{array}{r}\text { Quantum } \\
\text { yield, } \phi(\lambda)\end{array}$ & $\begin{array}{c}\text { Wavelength } \\
\lambda, \operatorname{nm}\end{array}$ & $\begin{array}{c}\text { Wavelength range } \\
\text { nm, for absorption } \\
\text { coefficients }\end{array}$ \\
\hline 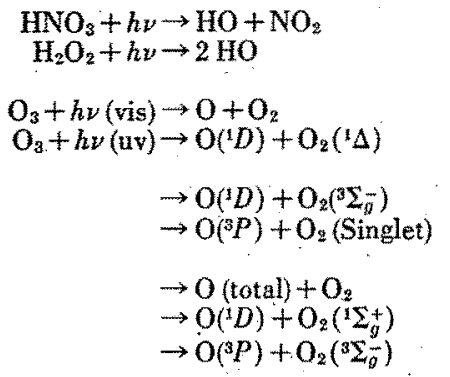 & $\begin{array}{c}\text { no recommendation* } \\
1 \\
1 \\
1 \\
0 \\
0 \\
0 \\
-1 \\
1 \\
0 \\
0\end{array}$ & $\begin{array}{c}200-300 \\
450-750 \\
250-310 \\
>310 \\
<350 \\
<310 \\
310-350 \\
250-350 \\
250-350 \\
250-350\end{array}$ & $\begin{array}{l}190-370^{*} \\
185-225 \\
254 \\
440-850 \\
200-360\end{array}$ \\
\hline
\end{tabular}

*Changed from value recommended in NBS Report 10828 (April 1972). 


\section{Introduction}

This review presents data sheets on the chemical kinetics and photochemistry of 28 gas phase reactions.

These reactions were selected for review on the basis that they are potentially important reactions in the chemistry and photochemistry of the stratosphere, the values for their rates and quantum yields were needed in models, and what value should be used was uncertain. Some of them had not been reviewed. For others, an updating or validation of an existing evaluation appeared desirable. Most of them also apply to tropospheric chemistry. They are part of a larger set of reactions that must be considered in models of the chemistry of the stratosphere. These data sheets are the first of a group that will cover this larger set of reactions.

The data sheets provide for each reaction:

An estimate, if possible, of the most reliable value for the rate constant or in the case of a photochemical system, for the photoabsorption coefficient and primary quantum yield.

An estimate of the reliability of that value.

Sufficient information to make apparent the basis for that value.

A summary of the available data.

The data sheets were prepared during the period July 1971-January 1973. The conclusions in them are based on the experimental work published or privately communicated to the reviewers or editor in completed manuscript form up to the date of preparation (which is shown on each data sheet). Summaries of data in each evaluation show all the work considered to be pertinent. Reference lists also include other papers examined by the evaluators.

Most of these data sheets were originally issued in references []] and [2].

In some instances, the recommendation has been changed by consideration of data published since the publication dates of these reports. These changes in preferred values are indicated in the data sheets.

\section{Evaluation of Data}

Each data sheet has been prepared by chemical kineticists or photochemists who are familiar with the measurement techniques and may have done research on this or closely related reactions. The evaluators are identified on each data sheet. Their conclusions are based on a critical examination of the available experimental data, an assessment of the techniques used, and a consideration of the behavior of related chemical systems.

The reader is warned that the state of the art varies sharply from reaction to reaction. In some cases a firm statement may be made about the rate constant or quantum yield. In others, all the evaluator can do is to point out the lack of data or the low reliability of the existing measurements. That type of information is important and must be considered by the user.

The conclusions of the evaluators are, necessarily, tentative. Atmospheric chemistry is an active research field. New data and new understanding of the experimental techniques will dictate revision of some of the results presented here. All that we can hope is that our recommendations reflect the best judgments of the data evaluators about the current state of the art.

\section{Description of Data Sheets}

The general form for a data sheet is described immediately below. Although this usually is followed, some modifications have been made, dictated by the type of material to be handled. Some conventions are explained in following section.

\subsection{Format of a Typical Data Sheet}

a. Statement of the chemical reaction or photochemical process considered and explicit definition of the chemical kinetic rate constant evaluated.

b. Auxiliary data (e.g. thermochemical data) and statement of related chemical reactions.

c. Summary of experimental chemical kinetic or photochemical data. Values of directly measured quantities are given rather than derived values based on auxiliary data. A brief statement of experimental conditions is included.

d. Preferred, selected, or estimated value for the quantity evaluated, i.e. chemical kinetic rate constant, photoabsorption coefficient, or primary photochemical quantum yield. A statement about the reliability of this value follows.

e. Remarks indicating the basis for the preferred value, comments on individual data items, and general discussion of the chemical system. Sometimes specific recommendations are made for additional studies to clarify areas of disagreement.

f. References. The name of the evaluator and the date of preparation follow the reference list.

\subsection{General Conventions}

a. Each Data Sheet is an independent entity. References to other data sheets are treated on the same basis as those to journal articles and reports.

b. Reactions and photochemical processes are numbered in a single sequence. This numbering is independent of that used in other data sheets. References are keyed by letters.

c. Physical quantities are given in units consistent with the (metric) International System of Units. Occasionally these are supplemented by values in units hallowed by tradition, e.g. $\mathrm{kcal} \mathrm{mol}^{-1}$ in addition to $\mathrm{kJ} \mathrm{mol}^{-1}$. In all cases the units are identified.

The value of a physical quantity shows only the sig- 
nificant figures. The last figure shown is, in most cases, subject to some uncertainty.

Charts are included (Appendix) for conversion of quantities from one system of units to another. Definitions and conventions concerning specific properties are given below.

\section{Rate Constant}

A rate constant for a chemical reaction, $k$, is a measure of the change in concentration of a species per unit concentration per unit time,

Almost all of the reactions evaluated here are elementary processes. For them the rate expression is derivable from the statement of the reactions:

$$
\begin{aligned}
& \nu_{\mathrm{A}}[\mathrm{A}]+\nu_{\mathrm{B}}[\mathrm{B}] \rightarrow \nu_{\mathrm{C}}[\mathrm{C}]+\nu_{\mathrm{D}}[\mathrm{D}] \\
& k[\mathrm{~A}]^{\nu} A[\mathrm{~B}]^{\nu} \mathrm{B}=\left(-1 / \nu_{\mathrm{A}}\right) d[\mathrm{~A}] / d t=\left(-1 / \nu_{\mathrm{B}}\right) d[\mathrm{~B}] / d t, \\
& =\left(1 / \nu_{\mathrm{C}}\right) d[\mathrm{C}] / d t=\left(1 / \nu_{\mathrm{D}}\right) d[\mathrm{D}] / d t
\end{aligned}
$$

as an example, for the reaction $\mathrm{A}+2 \mathrm{~B} \rightarrow \mathrm{AB}_{2}$,

$$
-d[\mathrm{~A}] / d t=-(1 / 2) d[\mathrm{~B}] / d t=d\left[\mathrm{AB}_{2}\right] / d t=k[\mathrm{~A}][\mathrm{B}]^{2} .
$$

Wherever there may be any doubt an explicit rate expression is given.

Rate constants are expressed using concentrations in (molecules $\mathrm{cm}^{-3}$ ) and time in seconds. This means that the units for integral order reactions are:

$\begin{array}{ll}\text { Ist order } & \mathrm{s}^{-1} \\ \text { 2d order } & \mathrm{cm}^{3} \text { molecule } \mathrm{s}^{-1} \\ \text { 3rd order } & \mathrm{cm}^{6} \text { molecule } \mathrm{s}^{-2} \mathrm{~s}^{-1}\end{array}$

Tables of conversion factors for units of rate constants are given in the Appendix.

Normally, the temperature dependence of a rate constant is shown using the Arrhenius expression: $k=A$ $\exp (-C / T)$ where $C$ is the activation energy divided by the gas constant, i.e. $E^{*} / R$.

\section{Equilibrium Constants}

Equilibrium constants, $K$, are given in concentration units. They are for mixtures of ideal gases. They are related to the usual equilibrium constants for pressure units by

$$
\log K=\log K_{P}-\Delta n \log (R T)
$$

where $\Delta \boldsymbol{n}$ is moles of products minus moles of reactants, $R$ is the gas constant, and $T$ the absolute temperature in Kelvin. The gas constant must have units consistent with the concentration units and the pressure units, e.g. $\mathrm{dm}^{3}$ atm $\mathrm{mol}^{-1} \mathrm{~K}^{-1}$ or $\mathrm{cm}^{3}$ atm molecule ${ }^{-1} \mathrm{~K}^{-1}$.

\section{Quantum Yield}

A quantum yield is a measure of the chemical change per quantum of light absorbed. Overall quantum yields in a system, indicated by the symbol uppercase phi, $\Phi$, include all changes caused by the primary light absorbing process and secondary reactions that follow it. The initial quantum yield, indicated by lowercase phi, $\phi$, is a measure of the change occurring solely in a single light absorbing step. Occasionally it is desirable to indicate what species was measured or the formal basis for recording the quantum yield, as for example, $\Phi$ $\left(-\mathrm{H}_{2} \mathrm{O}_{2}\right)$, for the total disappearance of hydrogen peroxide in its photolysis, or $\phi(\mathrm{OH})$ for product formation in $\mathrm{H}_{2} \mathrm{O}_{2}+h \nu \rightarrow 2 \mathrm{OH}$.

\section{Optical Absorption Coefficients}

Optical absorption coefficients are measures of the fraction of incident light transmitted by a sample per unit concentration and per unit length. They are defined and discussed in the introduction to a conversion chart in the Appendix. They are reported in data sheets either in figures or as numerical values. While we have attempted to use a consistent set of units for the numerical values, the figures retain the ordinates and abscissae used in the original publications.

d. The uncertainty in a preferred value given in a data sheet is the evaluator's estimate of that value's reliability. This is a subjective judgment that, to a high degree of probability, the true value of the quantity lies within the bounds indicated.

Uncertainties are indicated in several ways:

$A<k<B$ means $k$ lies in the range between $A$ and $B$.

$k<B$ means $B$ is an upper limit.

$k \sim B$ means that $B$ is only a rough guide to the value of $k$.

$k=A \pm B$ means that a reasonably reliable estimate of the likely error can be stated. This is an estimate by the evaluator of the absolute accuracy of the preferred value. It is a subjective judgment derived from intercomparison of data sets, consideration of related reactions studied with the same technique, estimates of how well the parameters could have been controlled, and comparison with theory. It means that in the evaluators judgment, the true value will lie within the indicated limits to a high level of confidence ( 90 to 95 percent).

Sometimes it is more appropriate to give $\log _{10} k=C \pm$ $D$, " $k$ uncertain to $E$ percent" or " $k$ uncertain to a factor of $F$ ", all three of which are equivalent statements of multiplicative limits. The statement that $k$ has the value $k_{0}$ and is uncertain to a factor of $F$ means $k_{0} / F<k<k_{0} F$.

Formally, substantial sets of parentheses are required when stating uncertainties using the plus or minus sign, e.g.

$$
k=(1.2 \pm 0.3) \times 10^{-9} \exp \left((-3.0 \pm 0.5) \times 10^{3} / T\right)
$$


These conventions are difficult to enforce. Therefore we permit the convention

$$
k=1.2 \pm 0.3 \times 10^{-9} \exp \left(-3.0 \pm 0.5 \times 10^{3} / T\right),
$$

based on the hierarchy of operators

$$
\pm>(\times, \div)>(+,-)
$$

\section{Acknowledgement}

In the preparation of these data sheets, it has occasionally been necessary to ask authors to clarify their published work. We wish to thank them for responding o questions and for supplying additional information and data. We are especially grateful to those who sup- plied data prior to their formal publication.

This work is supported by the Climatic Impact Assessment Program, Office of the Secretary, Department of Transportation, the Measures for Air Quality Program, N.B.S., and by the Office of Standard Reference Data, N.B.S.

\section{References}

[1] Hampson, R. F., ed., Chemical Kineties Data Survey I. Rate Data for Twelve Reactions of Interest for Stratospheric Chemistry, NBS Report 10692, National Bureau of Standards, Washington, D.C., Jan. 1972, 44 pp. Unpublished.

[2] Hampson, R. F., ed., Chemical Kinetics Data Survey II. Photochemical and Rate Data for Fifteen Gas Phase Reactions of Interest for Stratospheric Chemistry, NBS Report 10828, National Bureau of Standards, Washington, D.C., April 1972, 91 pp. Unpublished. 


\section{Data Sheets}

\subsection{The Reaction Between $H$ and $H N O$}

$\mathrm{H}+\mathrm{HNO} \rightarrow \mathrm{H}_{2}+\mathrm{NO}$

Auxiliary Data

$\Delta H_{298}^{\circ}=-227 \mathrm{~kJ} / \mathrm{mol}(-54.3 \mathrm{kcal} / \mathrm{mol})$

Data

\begin{tabular}{|c|c|}
\hline \multicolumn{2}{|r|}{ Data } \\
\hline $\begin{array}{c}k_{y}\left(\mathrm{~cm}^{3} \text { mole- }\right. \\
\left.\text { cule }^{-1} \mathrm{~s}^{-1}\right)\end{array}$ & System \\
\hline $\begin{array}{l}>5 \times 10^{-14} \\
(211-703 \mathrm{~K})\end{array}$ & $\begin{array}{l}\text { NO, Hz discharge, flow system. } \\
\text { Clyne, Thrush, } 1962 \text { (b); Thrush, } 1965 \text { (d). }\end{array}$ \\
\hline $\begin{array}{c}10 \pm 5 \times 10^{-12} \\
(1600-2000 \mathrm{~K})\end{array}$ & $\begin{array}{l}\mathrm{H}_{2}, \mathrm{O}_{2}, \mathrm{~N}_{2} \text {, NO flames. } \\
\text { Bulewicz, Sugden, 1964 (c) }\end{array}$ \\
\hline $\begin{array}{l}8 \pm 2 \times 10^{-12} \\
(2000 \mathrm{~K})\end{array}$ & $\begin{array}{l}\mathrm{H}_{2}, \mathrm{O}_{2}, \mathrm{~N}_{2} \text {, NO flames. Measured }[\mathrm{H}] \text { as function } \\
\text { of time. }\end{array}$ \\
\hline $\begin{array}{l}3.9 \pm 1.9 \times 10^{-12} \\
(2117 \mathrm{~K})\end{array}$ & $\begin{array}{l}\text { Halstead, Jenkins, } 1968(\mathrm{e}) \\
\mathrm{C}_{3} \mathrm{H}_{8,}, \mathrm{O}_{2}, \mathrm{~N}_{z} \text {, NO flames. Measured }[\mathrm{H}] \text { as } \\
\text { function of time. } \\
\text { Smith, } 1972(\mathrm{f})\end{array}$ \\
\hline
\end{tabular}

$k_{1}$

\section{Preferred Value}

Changed from that in NBS Report 10692 (Jan. 1972).)

ks $(211-703 \mathrm{~K})>5 \times 10^{-14} \mathrm{~cm}^{3}$ molecule $\mathrm{s}^{-1}$.

$k_{1}(2000 \mathrm{~K})=7 \times 10^{-12} \mathrm{~cm}^{3}$ molecule ${ }^{-1} \mathrm{~s}^{-1}$.

$k_{1}(2000 \mathrm{~K}) \mathrm{good}$ to a factor of 2 and may be good to a factor of 1.5 .

\section{Remarks}

Value of $k_{1}(2000 \mathrm{~K})$ chosen as simple average of values in ref. (c), (e), and (f). The combination of this result with the lower limit from $(b, d)$ leads to an upper limit of $10 \mathrm{~kJ} / \mathrm{mol}(2.3 \mathrm{kcal} / \mathrm{mol})$ for any activation energy.

References

(a) D. R. Stull and H. Prophet, JANAF Thermochemical Tables, $2 d$ Ed. Nat. Stand. Ref. Data Ser, Nat. Bur. Stand. (U.S.), 37 (June 1971),

(b) M. A. A. Clyne and B. A. Thrush, Disc. Faraday Soc. 33, 139 (1962).

(c) E. M. Bulewicz and T. M. Sugden, Proc. Roy. Soc. (London) A277, 143 (1964).

(d) B. A. Thrush, Progr. React. Kin. 3,63 (1965):

(e) C. J. Halstead and D. R. Jenkins, Chem. Phys. Lettrs. 2, 281 (1968).

(f) M. Y. Smith, Combustion and Flame 18, 293 (1972),

R. Brown

July, 1972

\subsection{The Reaction Between $\mathrm{H}$ and $\mathrm{HNO}_{2}$}

$\begin{aligned} \mathrm{H}+\mathrm{HNO}_{2} & \rightarrow \mathrm{H}_{2}+\mathrm{NO}_{2} \\ & \rightarrow \mathrm{H}_{2} \mathrm{O}+\mathrm{NO}\end{aligned}$

Auxiliary Data

$\Delta \mathrm{H}_{298}(\mathrm{I})=-105 \mathrm{~kJ} / \mathrm{mol}(-25.2 \mathrm{kcal} / \mathrm{mol})$

$\Delta \mathrm{H}_{298}(2)=-290 \mathrm{~kJ} / \mathrm{mol}(-69.3 \mathrm{kcal} / \mathrm{mol})$

\section{Data}

No data exist on these rate constants.

\section{Preferred Value}

None. $k_{1}$

$k_{2} \quad$ No information is available. The upper limit for the reaction $h\left(\mathrm{H}+\mathrm{HNO}_{3} \rightarrow\right.$ products $)<1 \times 10^{-13} \mathrm{~cm}^{3}$ molecule ${ }^{-1} \mathrm{~s}^{-1}$ by Morris and Niki (b) may be applicable. (a) The only justification is on the basis of structural and (a) energetic similarities. Clearly, if this should turn out to be an important reaction, its rate must be measured.

\section{References}

(a) D. D. Wagman, et al., NBS Technical Note 270-3 (Jan. 1968).

(b) E. D. Morris, Jr. and H. Niki, J. Phys. Chem. 75, 3193 (1971).

W. Tsang

August. 1971 
4.3. The Reaction Between $\mathrm{H}$ and $\mathrm{HNO}_{3}$

$$
\begin{aligned}
\mathrm{H}+\mathrm{HNO}_{3} & \rightarrow \mathrm{OH}+\mathrm{HNO}_{2} \\
& \rightarrow \mathrm{H}_{2}+\mathrm{NO}_{3} \\
& \rightarrow \mathrm{H}_{2} \mathrm{O}+\mathrm{NO}_{2}
\end{aligned}
$$

\section{Auxiliary Data}

$$
\begin{gathered}
\Delta H^{\circ}{ }_{298}(1)=-123 \mathrm{~kJ} / \mathrm{mol}(-29.5 \mathrm{kcal} / \mathrm{mol}) \\
\Delta H^{\circ}{ }_{298}(2)=-12 \pm 21 \mathrm{~kJ} / \mathrm{mol}(-3 \pm 5 \mathrm{kcal} / \mathrm{mol}) \\
\Delta H^{\circ}{ }_{298}(3)=-292 \mathrm{~kJ} / \mathrm{mol}(-69.7 \mathrm{kcal} / \mathrm{mol}) \\
\quad \quad \text { Data }
\end{gathered}
$$

Quantity measured
$\frac{k\left(\mathrm{H}+\mathrm{HNO}_{3}\right) \text { all charinels }}{k(\mathrm{H}+\text { trans-2-butene })}<0.1$

Discharge-flow system coupled with mass spectrometer. Traces of $\mathrm{HNO}_{3}\left(10^{12}\right.$ molecule $\left.\mathrm{cm}^{-3}\right)$ added to $\mathrm{H}$-atom rich $\left(10^{14}\right.$ atom $\left.\mathrm{cm}^{-3}\right)$ system. Rate of decay of $\mathrm{HNO}_{3}$ (monitored by $m / e=46$ peak, $\mathrm{NO}_{2}{ }^{+}$) compared with rate of decay of trans-2. butene under similar conditions.

Morris, Niki, 1971 (ref, d).

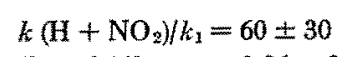

Photalysis of $\mathrm{HNO}_{3}$ at $265 \mathrm{~nm}$. in presence of $\mathrm{H}_{2}$. Relative quantum yield of decomposition of $\mathrm{HNO}_{3}$ (monitored by meas. of $\left[\mathrm{NO}_{2}\right]$ ) in presence and absence of $\mathrm{H}_{2}$ measured. Many step mechanism used to interpret data.

Berces, Forgeteg, 1970 (ref. c).
The preferred value is the upper limit derived in (d). It is based on the value of $k(\mathrm{H}+$ trans-2-butene $)=$ $9 \times 10^{-13} \mathrm{~cm}^{3}$ molecule ${ }^{-1} \mathrm{~s}^{-1}$ given in (e).

This relatively low value of $k$ suggests an activation energy in excess of $12 \mathrm{~kJ} / \mathrm{mol}(4 \mathrm{kcal} / \mathrm{mol})$.

\section{Comments on Measurements}

Ref. (c)

\section{Rejected.}

Johnston (f) has criticized the work in ref. (c) on the grounds of heterogeneity. He claims that the processes $\mathrm{NO}_{2}+h \nu \rightarrow \mathrm{NO}+\mathrm{O} ; \quad 4 \mathrm{HNO}_{3}+2 \mathrm{NO} \rightarrow 6 \mathrm{NO}_{2}+2 \mathrm{H}_{2} \mathrm{O}$ (heterogeneous) are of major importance. Note that the photolytic results are from the latter stages of the reaction and thus a large quantity of $\mathrm{NO}_{2}$ is in fact present. The $\mathrm{HNO}_{3} / \mathrm{H}_{2}$ ratio is also very close to the limit above which the authors feel that quantitative results are no longer valid (due to the considerations raised by Johnston).

Ref. $(d)$

This direct method accepted in preference to indirect method in (c).

It should be noted that the validity of the result in (d) may be affected by the fact that the mass 46 peak is also of importance in the mass spectra of $\mathrm{NO}_{2}$ and $\mathrm{NO}_{3}$. However the reaction of $\mathrm{H}$ atoms with $\mathrm{NO}_{2}$ (and possibly with $\mathrm{NO}_{3}$ ) is very fast. This will reduce the concentrations of these latter compounds.

\section{References}

(a) D. D. Wagman, et al. NBS Technical Note 270-3 (Jan. 1968).

(b) D. R. Stull and H. Prophet, JANAF Thermochemical Tables, 2d Ed. Nat. Stand. Ref. Data Ser., Nat. Bur. Stand. (U.S.), 37 June 1971).

(c) T. Berces, S. Forgeteg; and F. Marta, Trans, Far. Soc. 66, 648 (1970).

(d) E.D. Morris, Jr. and H. Niki, J. Phys. Chem. 75, 3193 (1971).

(e) E. E. Daby and H. Niki, J. Chem. Phys. 51, 1255 (1969).

(f) H. S. Johnston, Formation and Stability of Nitric Acid in the Stratosphere, typescript, University of California, Berkeley, California (1971).

W. Tsang

January, 1972

\section{$\left(k_{1}+k_{2}+k_{3}\right)<1 \times 10^{-13} \mathrm{~cm}^{3}$ molecule ${ }^{-1} \mathrm{~s}^{-1}$.}

\section{Auxiliary Data}

Two channels are possible for this reaction; they are

$\mathrm{H}+\mathrm{H}_{2} \mathrm{O}_{2} \rightarrow \mathrm{H}_{2}+\mathrm{HO}_{2}$

$\mathrm{H}+\mathrm{H}_{2} \mathrm{O}_{2} \rightarrow \mathrm{H}_{2} \mathrm{O}+\mathrm{HO}$
$\Delta H_{298}^{\circ}(1)=-61 \pm 8 \mathrm{~kJ} / \mathrm{mol}(-14.5 \pm 2 \mathrm{kcal} / \mathrm{mol})$

$\Delta H_{298}^{\circ}(2)=-284 \mathrm{~kJ} / \mathrm{mol}(-68.0 \mathrm{kcal} / \mathrm{mol})$

$\log _{10} K_{\text {ea. }}(1)=0.342+3.26(1000 / T)$

$\log _{10} K_{\text {eq. }}(2)=0.877+14.98(1000 / T)$ (a) 


\section{Data}

The available rate data have been presented and evaluated by Baulch, Drysdale, Horne, and Lloyd (c). There have been no more recent measurements.

Albers et al. (d) measured the total rate of removal of D atoms in a discharge-flow reactor from 294 to $464 \mathrm{~K}$ with 5-8 torr $\mathrm{H}_{2} \mathrm{O}_{2}$ and added $\mathrm{O}$ atoms to suppress the chain decomposition initiated by $\mathrm{OH}$. $\mathrm{D}$ atoms were monitored by ESR and mass spectrometry. They estimate the $k_{1} / k_{2} \approx 10$ for $\mathrm{D}$ atoms at $421 \mathrm{~K}$. Also they find $k_{1}^{(\mathrm{H})} / k_{1}^{(\mathrm{D})}=0.43$ at $375 \mathrm{~K}$. They give the result that $k^{(\mathrm{D})}+k_{2}^{(\mathrm{D})}=1.2 \times 10^{-11} \exp (-4200 / R T) \mathrm{cm}^{3}$ molecule $^{-1}$ $\mathrm{s}^{-1}$. (294-464 K).

Baldwin et al. (e) studied the decomposition of $\mathrm{H}_{2} \mathrm{O}_{2}$ in the presence of $\mathrm{H}_{2}$ from $713-773 \mathrm{~K}$. They report $k_{1} / k_{2}$ to have the value 0.143 over this temperature range (note: in the abstract this is incorrectly given as $0.125)$. Also they measure the ratio $k_{2} / k_{3}$ where (3) is $\mathrm{H}+\mathrm{O}_{2}+\mathrm{M} \rightarrow \mathrm{HO}_{2}+\mathrm{M}$. From this ratio and their previously measured values of $k_{3} / k_{4}$ where (4) is $\mathrm{H}+$ $\mathrm{O}_{2} \rightarrow \mathrm{HO}+\mathrm{O}$ they derive values of $k_{2} / k_{4}$. Baulch, et al. (c) use the values $k_{1} / k_{2}$ and $k_{2} / k_{4}$ in (e) with their own recommended expression for $k_{4}$ to obtain values of $k_{1}$. (Note: Because Baulch, et al. used the value of $k_{1} / k_{2}$ in Baldwin's abstract, the calculated values of $k_{1}$ given on p. 212 should be increased by $14 \%$; however this will not seriously affect their evaluation).

\section{Preferred Value}

$k_{1}=2.8 \times 10^{-12} \exp (-1900 / T) \mathrm{cm}^{3}$ molecule $\mathrm{s}^{-1}$ $(300-800 \mathrm{~K})$.
Uncertainty: factor of two.

No value is recommended for $k_{2}$.

Remarks

The recommendations of Baulch, et al. have been adopted. The value derived there for $k_{2}=3.7 \times 10^{-9}$ $\exp (-5900 / T) \mathrm{cm}^{3}$ molecule ${ }^{-1} \mathrm{~s}^{-1}$ as noted there can not be recommended with any confidence because of the unreasonably high value of the pre-exponential factor. By extrapolation, $k_{1}$ at stratospheric temperatures $(220 \mathrm{~K})$ is estimated to be $5 \times 10^{-16} \mathrm{~cm}^{3}$ molecule ${ }^{-1} \mathrm{~s}^{-1}$. From these expressions $k_{2} / k_{1}$ at $220 \mathrm{~K}$ is estimated to be $10^{-5}$, subject to a large uncertaint $y$.

\section{References}

(a) D. D. Wagman, et al, NBS Technical Note 270-3 (Jan. 1968).

(b) V. N. Kondratiev, Rate Constants of Gas Phase ReactionsReference Book, R. M. Fristrom, editor. National Technical Information Service, Springfield, Virginia COM-72-10014 (Jan. 1972):

(c) D. L. Baulch, D. D. Drysdale, D. G. Horne, A. C. Lloyd, Evaluated Kinetic Data for High Temperature Reactions volume 1, Homogeneous gas phase reactions of the $\mathrm{H}_{2}-\mathrm{O}_{2}$ system, Butterworth \& Co., London (1972).

(d) E. A. Albers, K. Hoyermann, H. Gg. Wagner, J. Wolfrum, 13th Combustion Symposium, 81 (1971).

(e) R. R. Baldwin, D. Brattan, B. Tunnidiffe, R. W. Walker, S. J Webster, Combustion and Flame 15, 133 (1970).

M. D. Scheer.

September, 1972

\subsection{The Reaction Between $\mathrm{H}$ and $\mathrm{NO}_{2}$}

$$
\mathrm{H}+\mathrm{NO}_{2} \rightarrow \mathrm{OH}+\mathrm{NO}
$$

Auxiliary Data

$\Delta H^{\circ}{ }_{298}=-122 \mathrm{~kJ} / \mathrm{mol}(-29.1 \mathrm{kcal} \mathrm{mol})$

Data

\begin{tabular}{|c|c|}
\hline Quantity measured & System \\
\hline $\begin{array}{l}k_{1}=4.8 \times 10^{-11} \mathrm{~cm}^{3} \text { male } \\
\text { cule }\end{array}$ & $\begin{array}{l}\text { Flow systern, } \mathrm{NO}_{2} \text {, microwave } \\
\quad \text { discharge in } \mathrm{H}_{2} / \mathrm{Ar} \text { on } \mathrm{H}_{2} / \mathrm{He} \\
\quad \text { mixt. } \\
\Delta[\mathrm{H}], \Delta\left[\mathrm{NO}_{2}\right] \text { meas. } 298 \mathrm{~K} \\
\text { Phillips, Sohif, } 1962 \text { (b). }\end{array}$ \\
\hline $\begin{array}{l}k_{1} / k\left(\mathrm{H}+\mathrm{Cl}_{2}\right)=0.16 \exp \\
\quad\left(1.58 \times 10^{3} / T\right)\end{array}$ & $\begin{array}{l}\mathrm{H}_{2}, \mathrm{Cl}_{2}, \mathrm{NO}_{2}(500-540 \mathrm{~K}) \\
\text { Rosser, Wise, } 1961 \text { (c). }\end{array}$ \\
\hline $\begin{array}{l}k_{1} / k\left(\mathrm{H}+\mathrm{O}_{2}+\mathrm{M}\right)=6 \times 10^{21} \\
\quad \text { molecules } \mathrm{cm}^{-3}\end{array}$ & $\begin{array}{l}\mathrm{H}_{2}, \mathrm{O}_{2}, \mathrm{NO}_{2} 633 \mathrm{~K} \text {, } \\
\qquad \mathrm{M}=\mathrm{H}_{2} \text { Also values for } \mathrm{M}= \\
\quad \mathrm{O}_{2}, \mathrm{~N}_{2}, \mathrm{CO}_{2}, \mathrm{H}_{2} \mathrm{O}, \mathrm{He} \text {. } \\
\text { Ashmote, Tyler, } 1962 \text { (d). }\end{array}$ \\
\hline
\end{tabular}

$k_{1}$

(a)
Estimated uncertainty: \pm 25 percent.

The above value and error limits are those given in (b). The rate was measured in $\mathrm{Ar}$ and He carriers and is 10 percent larger in He than in Ar. The difference is statistically significant and suggests that the observed reaction rate was partially limited by diffusion mixing of the reactants. An activation energy of $2 \mathrm{kcal} / \mathrm{mol}^{-1}$ $(8 \cdot \mathrm{kJ} / \mathrm{mol}$ ) results from combining the results at 298 $\mathrm{K}$ (b) and $633 \mathrm{~K}$ (d) using $k\left(\mathrm{H}+\mathrm{O}_{2}+\mathrm{H}_{z}\right)=5 \times 10^{-32}$ $\mathrm{cm}^{6}$ molecule $\mathrm{e}^{-2} \mathrm{~s}^{-1}$ at $633 \mathrm{~K}$ (g), following Schofield (f). A lower activation energy, $1.5 \mathrm{kcal} / \mathrm{mol}^{-1}(6 \mathrm{~kJ} / \mathrm{mol})$ results from combining the data in (b) and (c) using $k\left(\mathrm{H}+\mathrm{Cl}_{2}\right)=4.5 \times 10^{-11} \mathrm{~cm}^{3}$ molecule ${ }^{-1} \mathrm{~s}^{-1}$, extrapolating the evaluation in (h). There is no good basis for choosing between these. Measurements at temperatures below $273 \mathrm{~K}$ are needed. If the upper limiting value of $2 \mathrm{kcal} / \mathrm{mol}$ for the activation energy is used, then the 
estimated value for the rate constant at $220 \mathrm{~K}$ is one-third the value at $298 \mathrm{~K}$. The uncertainty at this temperature is unknown. A recent mass-spectrometric study of the stoichiometry of the reactions of $\mathrm{OH}$ generated by this reaction is reported in (e).

\section{References}

(a) D. D. Wagman, et al, NBS Technical Note $270-3$ (Jan. 1968),

(b) L. F. Phillips and H. I. Schiff, J. Chem. Phys. 37, 1233 (1962).

(c) W. A. Rosser and H. Wise, J. Phys. Chem. 65, 532 (1961); 65, $2277(1961)$.

(d) P. G. Ashmore and B. J. Tyler, Trans. Faraday Soc. 58, 1108 (1962). (e) M. F. R. Mulcahy and R. H. Smith, J. Chem. Phys. 54, 5215 (1971).

(f) K. Schofield, Planet. Space Sei. 15, 643 (1967).

(g) D. L. Baulch, D. D. Drysdale, and A. C. Lloyd, High Temperature Reaction Rate Data, Report No. 3 (April 1969), Department of Physical Chemistry, The University, Leeds, England.

(h) V. N. Kondratiev, Rate Constants of Gas Phase ReactionsReference Book, R. M. Fristrom, editor. National Technical Information Service, Springfield, Virginia, COM-72-10014 (Jan. 1972).

R. L. Brown

February 1972

\subsection{The Reaction Between $\mathrm{H}$ and $\mathrm{O}_{3}$}

$\mathrm{H}+\mathrm{O}_{3} \rightarrow \mathrm{OH}\left(X^{2} \Pi, v>0\right)+\mathrm{O}_{2}$

Auxiliary Data

$\Delta H_{298}^{\mathrm{o}}=-322 \mathrm{~kJ} / \mathrm{mol}(-76.9 \mathrm{kcal} / \mathrm{mol})$

Data

\begin{tabular}{l|l}
\hline$k_{1}\left(\mathrm{~cm}^{3}\right.$ molecule & \\
\hline$(2.6 \pm 0.5) \times 10^{-11}$ & System \\
\hline
\end{tabular}

electric discharge. $\mathrm{O}_{3}$ or $\mathrm{H}$ at pressure $<5 \times 10^{-4}$ torr. $0.17<\mathrm{H} / \mathrm{O}_{3}<3$. Total pressure 0.5 torr (He or Ar). Mass spec. measurement of $\mathrm{H}, \mathrm{O}_{3}$. Reaction time - a few ms. 24 measurements.

Phillips, Schiff, 1962 (b).

$-2 \times 10^{-11}$

$(4 \pm-1) \times 10^{-12}$
Room temp. flow system. $\mathrm{O}_{3}$ (in $\mathrm{O}_{2}$ mixed with $\mathrm{H}$ and $\mathrm{H}_{2}$ (in $\left.\mathrm{Ar}\right)[\mathrm{H}] \sim\left[\mathrm{O}_{3}\right] \sim 6 \times 10^{11}$ molecule $\mathrm{cm}^{-3}$ with total $[\mathrm{M}] /\left[\mathrm{O}_{3}\right] \sim 100$ Enission from HOł measured.

Potter, Coltharp, Worley, 1971 (f).

Room temp., Polanyi diffusion flame $\mathrm{O}_{3}$ mixed into $\mathrm{H} / \mathrm{H}_{2}$ atmosphere. Pressure $\sim 0.08$ torr. $7<\mathrm{H} / \mathrm{O}_{3}<20$. Measured spatial distribution of $\mathrm{OH}$ emission. 2 measurements.

Garvin, McKinley, 1956 (c).

Preferred value

$k_{1}(298 \mathrm{~K})=2.6 \times 10^{-11} \mathrm{~cm}^{3}$ molecule $\mathrm{e}^{-1} \mathrm{~s}^{-1}$.

Estimated uncertaint y: \pm 25 percent.

Remarks

The $\mathrm{OH}$ is formed to a large extent in vibrational levels $k_{1} \quad 4-9$ of the ground state. At $\sim 1$ torr significant collisional and reactive quenching occurs in the rate experiments. The most recent effort to determine the initial vibrational level populations is by Charters, MacDonald, and Polanyi (d). Earlier work is summarized there.

The suggested rate and uncertainty are quoted from ref. (b), the most extensive study. This value also was selected by Kaufman (e). The validity of the result depends upon whether or not the reaction times ( 1 to $5 \mathrm{~ms}$ ) are short enough to support their assumption that reaction (1) is "extremely rapid in comparison with the secondary reactions". $\mathrm{OH}^{*}+\mathrm{O}_{3} \rightarrow \mathrm{HO}_{2}+\mathrm{O}_{2}$ is the primary worry (e). The approximate value from ref. (f) supports this selection.

The other rate measurement (ref. c) depends strongly upon the choice of a diffusion coefficient, the precise shape of the distribution of $\mathrm{OH}$ radiation, and the extent of rapid secondary reactions (ref. e). (The last would increase the observed rate.) Likely reactions are $\mathrm{OH}^{*}+\mathrm{H}_{2}$ and $\mathrm{OH}^{*}+\mathrm{H}$. Because of these uncertainties this measurement is rejected.

\section{References}

(a) D. D. Wagman, et al., NBS Tech. Note 270-3 (Jan. 1968).

(b) L. F. Phillips and H. I. Schiff, J. Chem. Phys. 37, 1233 (1962).

(c) D. Garvin and J. D. MeKinley, J. Chem. Phys. 24, 1256 (1956).

(d) P. E. Charters, R. G. MacDonald, and J. C. Polanyi., Applied Optics 10, 1747 (1971).

(e) F. Kaufman, Can. J. Chem. 47, 1917 (1969); F. Kaufman, Ann. Geophys. 20, 106 (1964).

(f) A. E. Potter, Jr., R. N. Coltharp, and S. D. Worley, J. Chem. Phys 54, 992 (3971).

J. D. McKinley, D. Garvin

January, 1973 


\subsection{The Reaction Between $\mathrm{HNO}$ and $\mathrm{HO}$}

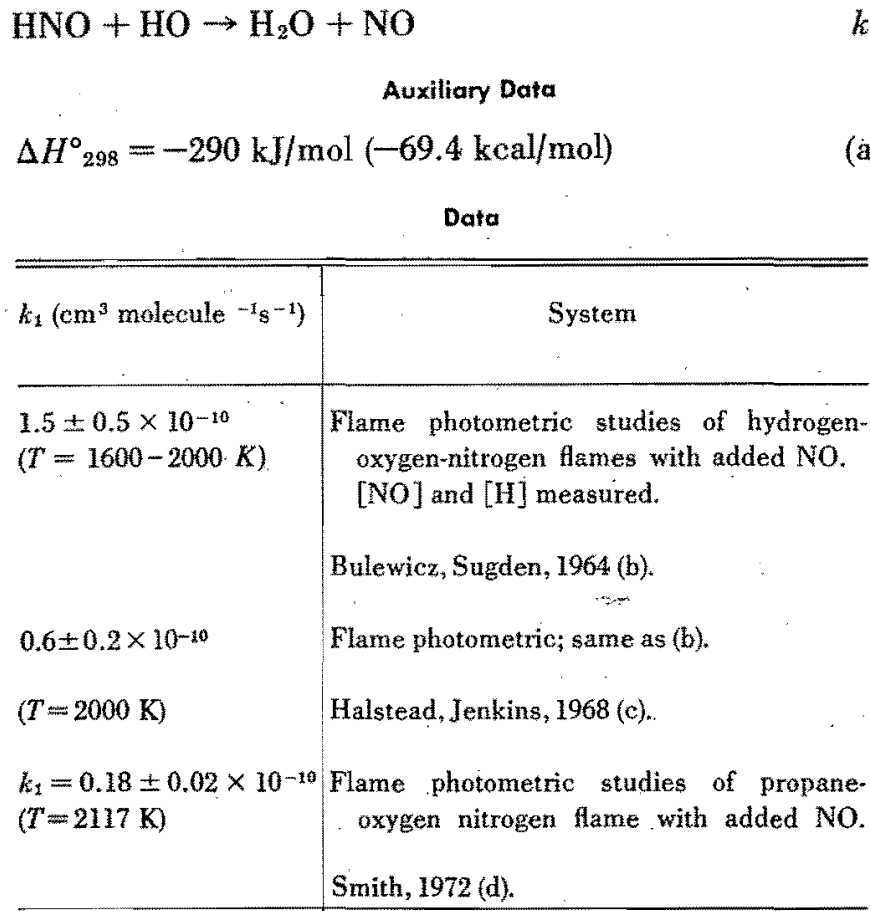

Preferred Value

Changed from that in NBS Report 10692 (Jan. 1972). $k_{1}=7 \times 10^{-11} \mathrm{~cm}^{3}$ molecule ${ }^{-1} \mathrm{~s}^{-1}$ over temperature range $1600-2100 \mathrm{~K}$. The three reported values have been averaged. Absolute uncertainty is no less than a factor of 5 . $k_{1}$ $k_{3}, k_{-3}$
$k_{2}$
$k_{1}$

The experimentally determined quantity is $K_{3} k_{1}$. $K_{3}$ is derived from JANAF tables (a). The data from ref. (d) is from a more complex system $(\mathrm{C}, \mathrm{H}, \mathrm{O}, \mathrm{N})$ than in (b) and (c) $(\mathrm{H}, \mathrm{O}, \mathrm{N})$. Thus additional complications may be present. Experiments in (d) are also carried out at considerably higher $[\mathrm{OH}] / \mathrm{H}]$ levels than in (b) and (c).

References

(a) D. R. Stull and H. Prophet JANAF Thermochemical Tables $2 d$ Ed. Nat. Stand. Ref. Data Ser., National Bureau of Standards (U.S.), 37 (June 1971).

(b) E. Bulewicz and T. Sugden, Proc. Roy. Soc. (London) A277, 143 (1964).

(c) C. J. Halstead and D. R. Jenkins, Chemical Physics Letters. 2, 281 (1968).

(d) M. Y. Smith, Combustion and Flame, 18,293 (1972).

W. Tsang

July, 1972

\subsection{The Reaction Between $\mathrm{HNO}_{2}$ and $\mathrm{HO}$}

$$
\begin{gathered}
\mathrm{HNO}_{2}+\mathrm{HO} \rightarrow \mathrm{H}_{2} \mathrm{O}+\mathrm{NO}_{2} \\
\text { Auxiliary Data } \\
\Delta H_{298}^{\circ}=-168 \mathrm{~kJ} / \mathrm{mol}(-40.2 \mathrm{kcal} / \mathrm{mol}) \\
\text { Data }
\end{gathered}
$$

No data exist on the rate of this reaction.

$$
\text { Preferred Value }
$$

(Changed from that in NBS Report 10692 (Jan. 1972).) None

\section{Remarks}

The Arrhenius expression for the rate constant may be similar to that for the reaction of $\mathrm{HO}$ with $\mathrm{HNO}_{3}$, for which the rate expression is (see separate data sheet):

$k\left(\mathrm{HO}+\mathrm{HNO}_{3} \rightarrow \mathrm{H}_{2} \mathrm{O}+\mathrm{NO}_{3}\right)=6 \times 10^{-13} \times$ $\exp (-400 / T)_{1} \mathrm{~cm}^{3}$ molecule ${ }^{-1} \mathrm{~s}^{-1}$ $k_{1} \quad$ Demerjian, Kerr, and Calvert (b) prefer a value of $7 \times 10^{-12} \mathrm{~cm}^{3}$ molecule ${ }^{-1} \mathrm{~s}^{-1}$ using as a basis the reported value of $14 \times 10^{-12} \mathrm{~cm}^{3}$ molecule ${ }^{-1} \mathrm{~s}^{-1}(\mathrm{c})$ for the reaction $\mathrm{HO}+\mathrm{H}_{2} \mathrm{CO} \rightarrow \mathrm{H}_{2} \mathrm{O}+\mathrm{HCO}$ and the argument that since the enthalpies of these hydrogen atom abstraction reactions are similar; the rate constants per abstractable hydrogen atom must be similar.

Clearly, if this reaction is of any importance, a direct measurement of $k_{1}$ is needed.

\section{References}

(a) D. D. Wagman, et al., NBS Technical Note 270-3 (Jan. 1968).

(b) K. L. Demeriian, J. A. Kerr, and J. G. Calvert, The Mechanism of Photochemical Smog Formation, typescript, Ohio State Univ. (1972) [to appear in Adv. in Environmental Sci. and Technology, J. N. Pitts, Jr., and R. L. Metcalf, editors, Wiley-Interscience (Vol. 4, 1974)].

(c) E. D. Morris and H. Niki, J, Chem. Phys. 55, 1991 (1971).

W. Tsang

August, 1971

Revised: January, 1973 


\subsection{The Reaction Between $\mathrm{HNO}_{2}$ and $\mathrm{O}$}

$$
\begin{gathered}
\mathrm{HNO}_{2}+\mathrm{O} \rightarrow \mathrm{HO}+\mathrm{NO}_{2} \\
\mathrm{HNO}_{2}+\mathrm{O} \rightarrow \mathrm{HNO}+\mathrm{O}_{2} \\
\text { Auxiliary Data } \\
\Delta H_{298}^{\circ}(\mathrm{a})=-98 \mathrm{~kJ} / \mathrm{mol}(-23.3 \mathrm{kcal} / \mathrm{mol}) \\
\Delta H_{298}^{\circ}(\mathrm{b})=-70 \mathrm{~kJ} / \mathrm{mol}(-16.8 \mathrm{kcal} / \mathrm{mol}) \\
\text { Data }
\end{gathered}
$$

There are no published data on the rate of this reaction.

$$
\text { Preferred Value }
$$

None.

\section{Remarks}

Note that there are two possible reactions; the $\mathrm{H}$-atom abstraction ( $\mathrm{la}$ ) and the $\mathrm{O}$-atom abstraction (1b).

\section{References}

(a) D. D. Wagran, et al, NBS Technical Note 270-3 (Jan. 1968).

\begin{tabular}{|c|c|c|c|}
\hline \multicolumn{4}{|c|}{ Primary Phatochemical Transitions } \\
\hline \multirow{2}{*}{ Réaction } & \multicolumn{2}{|c|}{$\Delta H_{0}^{\circ}$} & \multirow{2}{*}{$\lambda_{\text {threshotid (nm) }}$} \\
\hline & $\mathrm{kJ} / \mathrm{mol}$ & $(\mathrm{kcal} / \mathrm{mol})$ & \\
\hline $\mathrm{HNO}_{3} \rightarrow \mathrm{HO}+\mathrm{NO}_{2}$ & $200 . \cdots$ & $(48)$ & 600 \\
\hline $\mathrm{HNO}_{3} \rightarrow \mathrm{HNO}_{2}+\mathrm{O}$ & 298 & (71) & 400 (2) \\
\hline $\mathrm{HNO}_{3} \rightarrow \mathrm{H}+\mathrm{NO}_{3}$ & 418 & $(100)$ & $286 \quad(3)$ \\
\hline
\end{tabular}
Data on HNO from D. R. Stull and H. Prophet, JANAF Thermochemical Tables, $2 d$ Ed., Nat. Stand. Ref. Data Ser, Nat. Bur. Stand. (U.S.), 37 (June 1971).

J. T. Herron, R. E. Huie

February, 1972

4.10. Photolysis of $\mathrm{HNO}_{3}$

$\Delta H_{0}^{\circ}$ calculated from $\Delta H_{f}^{\circ}$ values in ref. (a) except for $\Delta H_{f}^{\circ}\left(\mathrm{NO}_{3}\right)$ which is from ref. (b) but is consistent with ref. (a).

\section{Data}

Absorption coefficient

$370-190 \mathrm{~nm}$

$320-168 \mathrm{~nm}$

Absorption, cross section $\sigma=2.6$ $\times 10^{-20} \mathrm{~cm}^{2}$ at $265,254 \mathrm{~nm}$
$\left[\mathrm{HNO}_{3}\right]$ varied between $8 \times 10^{\text {t3 }}$ and $6 \times 10^{16}$ molecules $\mathrm{cm}^{-3}$. Path lengths were 8.6 to 34.4 m. Data given in table 1 and shown in fig. 1 for $325-190 \mathrm{~nm}$. Absorption cross section $\sigma<<10^{-22} \mathrm{~cm}^{2}$ for $370-330$ nm.

Johnston, Graham, 1973 (f).

$\left[\mathrm{HNO}_{3}\right]$ varied between 2.5 $\times 10^{16}$ and $1.5 \times 10^{18}$ molecules 12.31 or $0.97 \mathrm{~cm}$.

Schmidt, Amme, Murcray, Goldman, Bonomo, 1972 (h).

Densitometry of photographic

\begin{tabular}{|c|c|c|}
\hline & & Quantum yields \\
\hline$\lambda$ & $\Phi\left(-\mathrm{HNO}_{3}\right)$ & \\
\hline $\begin{array}{l}265 \mathrm{~nm} \\
254 \mathrm{~nm} \\
\quad \therefore\end{array}$ & $\begin{array}{c}0.2 \pm 0.03 \\
0.6 \pm 0.07 \\
\end{array}$ & $\begin{array}{l}\text { Steady room temperature photolysis } \\
\text { of pure } \mathrm{HNO}_{3} \text { and } \mathrm{HNO}_{3}-\mathrm{O}_{2} \text { mixt. } \\
\mathrm{HNO}_{3}-\mathrm{NO}_{2}, \mathrm{HNO}_{3}-\mathrm{H}_{2} \text {, and } \mathrm{HNO}_{3}- \\
\mathrm{CO} \text { mixtures photolyzed at } 265 \mathrm{~nm} \text {. } \\
\text { Berces, Forgeteg, } 1970 \text { (c). }\end{array}$ \\
\hline
\end{tabular}
plates. $\left[\mathrm{HNO}_{3}\right]=5 \times 10^{16} \mathrm{~mol}$ ecules $\mathrm{cm}^{-3}$. Path length $=75 \mathrm{~cm}$. See table 1 .

Dalmon, 1943 (e)

Berces, Forgeteg, 1970 (c). $\mathrm{cm}^{-3}$. Path length was either
(Changed. from that in NBS Report 10828 (April 1972).)

\begin{tabular}{c|c} 
Absorption coefficient \\
\hline $370-190 \mathrm{~nm}$ & $\begin{array}{l}\text { Use data in ref. (f). See figure } 1 \text { and table } 1 \text { for } \\
325-190 \mathrm{~nm} . \text { Absorption cross section } \sigma \ll 10^{-22} \\
\mathrm{~cm}^{2} \text { for } 370-330 \mathrm{~nm} .\end{array}$ \\
\hline
\end{tabular}

\section{Remarks}

\section{Absorption Coefficients}

The recent measurements by Johnston and Graham (f) are in good agreement with the earlier results of Dalmon (e) over the common range $300-230 \mathrm{~nm}$ except near $300 \mathrm{~nm}$, which it is suggested in (f) can be accounted for by a 1.5 percent $\mathrm{NO}_{2}$ impurity in the nitric acid used in (e).

Schmidt (private communication) has stated that the data shown in ref. (h) for $\lambda>320 \mathrm{~nm}$ are 2 nd order grating spectra and should be disregarded and also that the $\mathrm{NO}_{2}$ impurity in the nitric acid was overestimated. Their results now agree favorably with those of Dalmon (e) and also with those of Johnston and Graham (f). A statistical band model analysis is cur. rently being developed by S. C. Schmidt and A. Goldman to interpret their observed pressure dependence of the absorption coefficient.

\section{Quantum Yields}

No value is recommended for the primary quantum 
yield of decomposition of nitric acid. Measurements of this quantity are now in progress ref. $(\mathrm{g})$ and preliminary results indicate that the primary quantum yields $\phi_{1}$ is equal to unity throughout the wavelength region $300-190 \mathrm{~nm}$.

Process (1) appears to be established from the production of $\mathrm{HO}$ in the flash photolysis of $\mathrm{HNO}_{3}$ (3-10 torr) in presence of 500 torr $\mathrm{N}_{2}$ (ref. d).

There is no positive evidence that processes (2) and (3) are of importance in the region 200-300 nm. Assuming that (1) is the only primary process; the complete mechanism of photolysis is the following:

$$
\begin{aligned}
\mathrm{HNO}_{3}+h \nu & \rightarrow \mathrm{HO}+\mathrm{NO}_{2} \\
\mathrm{HO}+\mathrm{NO}_{2}+\mathrm{M} & \rightarrow \mathrm{HNO}+\mathrm{M} \\
\mathrm{HO}+\mathrm{HNO}_{3} & \rightarrow \mathrm{H}_{2} \mathrm{O}+\mathrm{NO}_{3} \\
\mathrm{NO}_{3}+\mathrm{NO}_{2} & \rightarrow \mathrm{NO}+\mathrm{NO}_{2}+\mathrm{O}_{2} \\
\mathrm{NO}_{3}+\mathrm{NO} & \rightarrow 2 \mathrm{NO}_{2}
\end{aligned}
$$

The quantum yield of $\mathrm{HNO}_{3}$ disappearance, $\Phi\left(-\mathrm{HNO}_{3}\right)$ is:

$$
\Phi\left(-\mathrm{HNO}_{3}\right)=\frac{2 \phi_{1}}{1+\left(k_{4}\left[\mathrm{NO}_{2}\right][\mathrm{M}] / k_{5}\left[\mathrm{HNO}_{3}\right]\right)}
$$

where $\phi_{1}$ is the quantum yield of process $(1)$.

In the photolysis of pure $\mathrm{HNO}_{3}$ at low conversion $k_{4}\left[\mathrm{NO}_{2}\right][\mathrm{M}] \ll k_{5}\left[\mathrm{HNO}_{3}\right]$ and therefore,

$$
\phi_{1}=(1 / 2) \times \Phi\left(-\mathrm{HNO}_{3}\right)
$$

\section{References}

(a) D. D. Wagman et al, NBS Tech. Note 270-3 (Jan. 1968).

(b) D. R. Stull and H. Prophet, JANAF Thermochemical Tables, $2 d$ Ed., Nat. Stand. Ref. Data Ser., Nat. Bur. Stand. (U.S.) 37 (June 1971).

(c) T. Berces and S. Forgeteg, Trans. Faraday Soc. 66, 633, 640, $648(1970)$.

(d) D. Husain and R. G. W. Norrish, Proc. Roy. Soc. (London) A273, $165(1963)$.

(e) R. Dalmon, Mem. serv. chim. etat, 30, 141 (1943).

(f) H. Johnston and R. Graham, J. Phys. Chem. 77, 62 (1973),

(g) H. Johnston, private communication.

(h) S. C. Schmidt, R. C. Amme, D. G. Murcray, A. Goldman, and F. S. Bonomo, Nature 238, 109 (1972).

\section{Acknowledgement}

We thank Drs. Schmidt, Berces, and Johnston for

\begin{tabular}{|c|c|c|c|c|}
\hline$\stackrel{\lambda}{\mathrm{nm}}$ & $\begin{array}{l}\sigma, \mathrm{cm}^{2} \\
\text { Dalmon }\end{array}$ & This & $\sigma^{2}$ & $\begin{array}{l}\text { Standard } \\
\text { deviation }\end{array}$ \\
\hline 190 & & 1.32 & $(-17)^{*}$ & 3 \\
\hline 195 & & 9.1 & $(-18)$ & 3 \\
\hline 200 & & 5.5 & $(-18)$ & 3 \\
\hline 205 & & 2.55 & $(-18)$ & 3 \\
\hline 210 & & 9.7 & $(-19)$ & 3 \\
\hline 215 & & 3.28 & $(-19)$ & 3 \\
\hline 220 & & 1.44 & $(-19)$ & 3 \\
\hline 225 & & 8.51 & $(-20)$ & I \\
\hline 230 & $5.35(-20)^{*}$ & 5.63 & $(-20)$ & 1 \\
\hline 235 & $3.59 \quad(-20)$ & 3.74 & $(-20)$ & 1 \\
\hline 240 & $2.56 \quad(-20)$ & 2.60 & $(-20)$ & 1 \\
\hline 245 & $2: 10 \quad(-20)$ & 2.10 & $(-20)$ & 1 \\
\hline 250 & $1.93 \quad(-20)$ & 1.95 & $(-20)$ & 1 \\
\hline 255 & $1.91 \quad(-20)$ & 1.94 & $(-20)$ & 1 \\
\hline $260^{\circ}$ & $1.93 \quad(-20)$ & 1.90 & $(-20)$ & 1 \\
\hline 265 & $1.91 \quad(-20)$ & 1.80 & $(-20)$ & 1 \\
\hline 270 & $1.64 \quad(-20)$ & 1.63 & $(-20)$ & 1 \\
\hline 275 & $1.34 \quad(-20)$ & 1.40 & $(-20)$ & 1 \\
\hline 280 & $1.07 \quad(-20)$ & 1.14 & $(-20)$ & 1 \\
\hline 285 & $8.79 \quad(-21)$ & 8.77 & $(-21)$ & 1 \\
\hline 290 & $7.26 \quad(-21)$ & 6.34 & $(-21)$ & 1 \\
\hline $295^{\circ}$ & $5.73 \quad(-21)$ & 4.26 & $(-21)$ & 5 \\
\hline 300 & $4.59 \quad(-21)$ & 2,76 & $(-21)$ & 5 \\
\hline 305 & $\therefore$ & 1.68 & $(-21)$ & 5 \\
\hline 310 & & 9.5 & $(-22)$ & 5 \\
\hline 315 & & 4.7 & $(-22)$ & 5 \\
\hline 320 & & 1.8 & $(-22)$ & 5 \\
\hline 325 & & 2 & $(-23)$ & $>10$ \\
\hline
\end{tabular}
providing us with additional information on their measurements of the absorption coefficient of $\mathrm{HNO}_{3}$.

\section{H. Okabe}

Dec. 1971

Revised: January, 1973
TABLE 1. Ultraviolet absorption spectrum for nitric acid vapor

*5.35 $(-20)$ means $5.35 \times 10^{-20} ; \ln \left(I_{0} / I\right)=\sigma\left[\mathrm{HNO}_{3}\right] L$.

From Johnston, Graham (f) with permission of authors.

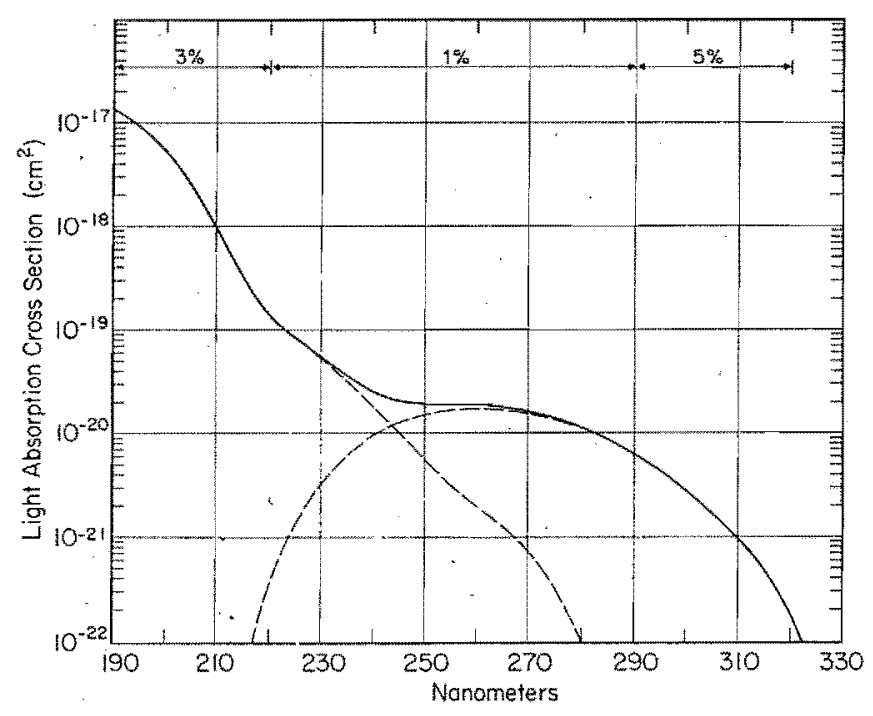

FIGURE 1. The ultraviolet absorption spectrum of nitric acid vapor; In $\left(I_{0} / I\right)=o\left[\mathrm{HNO}_{3}\right] L$, where $\left[\mathrm{HNO}_{3}\right]$ is in molecules $\mathrm{cm}^{-3}$ and $L$ is optical path in $\mathrm{cm}$. The percentages at the top of the figure refer to the standard deviation based on 15 gas samples (from Johnston, Graham (f) with permission of authors). 


\subsection{The Reaction Between $\mathrm{HNO}_{3}$ and $\mathrm{HO}$}

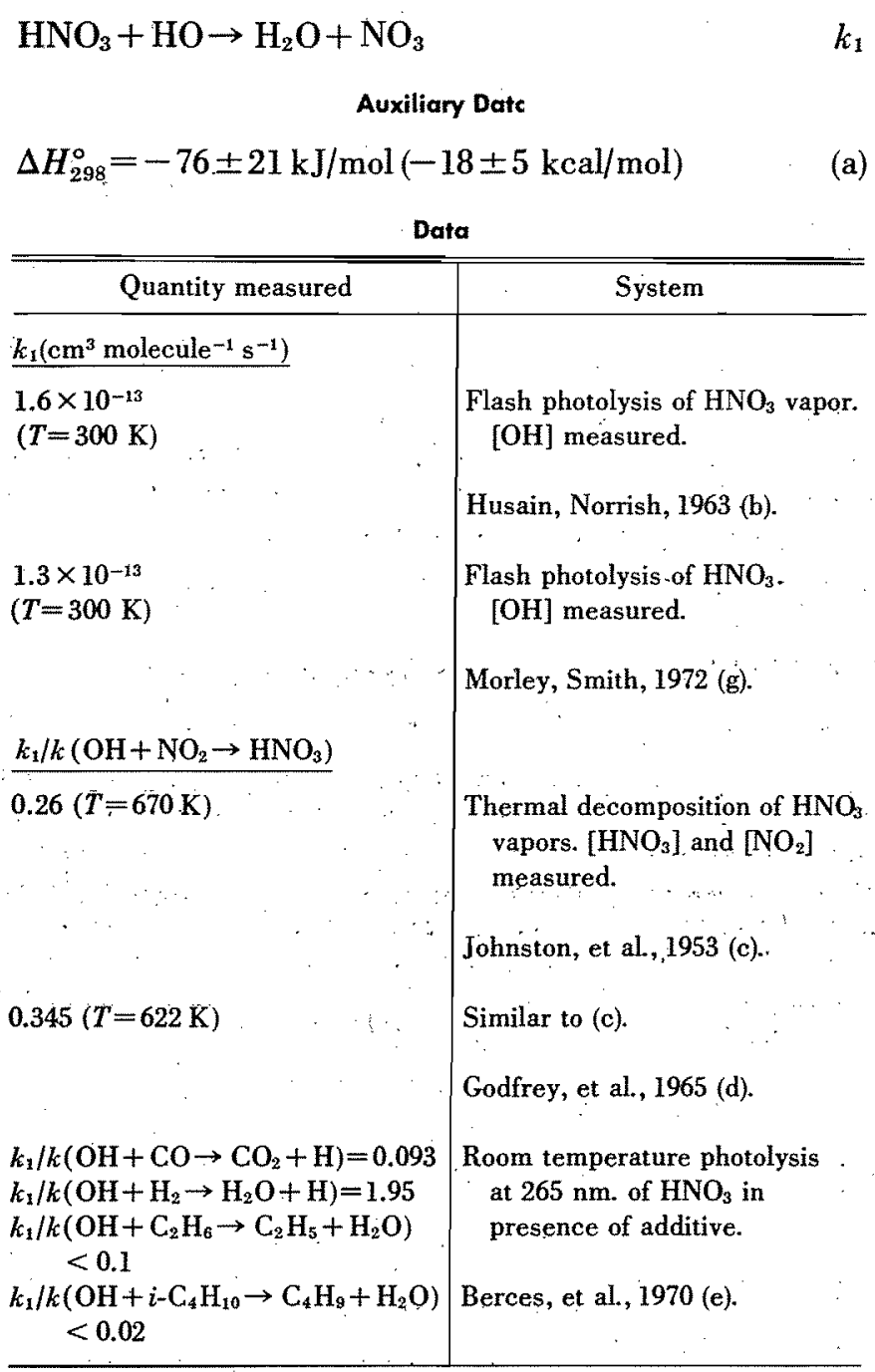

\section{Preferred Value}

(Changed from that in NBS Report 10692 (Jan. 1972).)

$k_{1}(300 \mathrm{~K})=1.4 \times 10^{-13} \mathrm{~cm}^{3}$ molecule ${ }^{-1} \mathrm{~s}^{-1}$.

$k_{1}(650 \mathrm{~K})=3 \times 10^{-13}$.

Estimated uncertainty is a factor of three.

Inserting these values into the Arrhenius equation gives:

$$
\begin{gathered}
k=6 \times 10^{-13} \exp [-400 / T] \mathrm{cm}^{3} \text { molecule }{ }^{-1} \mathrm{~s}^{-1} . \\
\text { Remarks }
\end{gathered}
$$

Ref. (b)

Value is undoubtedly a good upper limit.

Ref. (c)

Reaction is homogeneous at $T>570 \mathrm{~K}$. The mechanism considered is: $k_{1} \quad \mathrm{HNO}_{3} \rightleftarrows \mathrm{HO}+\mathrm{NO}_{2} \quad k_{2}, k_{3}$

$\mathrm{HO}+\mathrm{HNO}_{3} \rightarrow \mathrm{H}_{2} \mathrm{O}+\mathrm{NO}_{3} \quad k_{1}$

At $670 \mathrm{~K}, k_{2}=0.16 \mathrm{~s}^{-1}$ and $k_{1} / k_{3}=0.26$. From data in ref. (a), $k_{2} / k_{3}=1.8 \times 10^{11}$ molecules $/ \mathrm{cm}^{3}$, and the derived value of $k_{1}$ is $2.4 \times 10^{-13} \mathrm{~cm}^{3}$ molecule ${ }^{-1} \mathrm{~s}^{-1}$. This result will not change even if reaction (3) is not truly bimolecular.

Ref. (d)

The mechanism considered is the same as in (c). At $622 \mathrm{~K}$ and 680 torr total pressure $k_{2}=0.0125 \mathrm{~s}^{-1}$ and $k_{1} / k_{3}=0.345$. From data in ref. (a), $k_{2} / k_{3}=1 \times 10^{10}$ molecules $/ \mathrm{cm}^{3}$, and the derived value of $k_{1}$ is $4 \times 10^{-13} \mathrm{~cm}^{3}$ molecule ${ }^{-1} \mathrm{~s}^{-1}$ in excellent agreement with (a). However lowering the total pressure to 230 torr results in a decrease in value of $k_{1}$ which conflicts with the mechanism and disagrees with (a).

Ref. (e)

The quantum yields for disappearance of $\mathrm{HNO}_{3}$ in the presence and absence of added gas were measured. For $\mathrm{CO}$ and $\mathrm{H}_{2}$ as additives, from the measured ratios and the well established values of $k(\mathrm{OH}+\mathrm{CO})$ and $k(\mathrm{OH}+$ $\left.\mathrm{H}_{2}\right)(f)$, the value of $k_{1}$ is calculated to be $1.3 \times 10^{-14}$ $\mathrm{cm}^{3}$ molecule ${ }^{-1} \mathrm{~s}^{-1}$. The values based on the reactions with hydrocarbons are rough estimates. The value of the rate constant derived from these experiments is a factor of 10 lower than the direct determinations $(b, g)$. Since it must be derived on the basis of a complex mechanism and difficult experiments, it is rejected in favor of the direct measurements.

\section{References}

(a) D. R. Stull and H. Prophet, JANAF Thermochemical Tables, 2d Ed., Nat. Stand. Ref. Data Ser., Nat. Bur. Stand. (U.S.), 37 (June 1971).

(b) D. Husain and R. G. W. Norrish, Proc. Roy. Soc. (London) A165, 273 (1963).

(c) H. S. Johnston, L., Foering, and R. J. Thompson, J. Phys. Chem. 57, 390 (1953).

(d) T. S. Godfrey, E. D. Hughes, and C. Ingold, J. Chem. Soc. 1063 (1965).

(e) T. Berces, S. Forgeteg, and F. Marta, Trans. Far. Soc. 66, 648 (1967).

(f) N. R. Greiner, J. Chem. Phys. 46, 2795 (1967).

(g) C. Morley and I. W. M. Smith, J. Chem. Soc. Far. Trans. II 68, 1016 (1972).

W. Tsang

August, 1971

Revised: January, 1973 


\subsection{The Reaction Between $\mathrm{HNO}_{3}$ and $\mathrm{O}$}

$$
\mathrm{HNO}_{3}+\mathrm{O} \rightarrow \mathrm{HO}+\mathrm{NO}_{3}
$$

Auxiliary Data

$$
\Delta H_{298}^{\circ}=-4 \pm 21 \mathrm{~kJ} / \mathrm{mol}(-\mathrm{l} \pm 5 \mathrm{kcal} / \mathrm{mol})
$$

$$
\text { Data }
$$

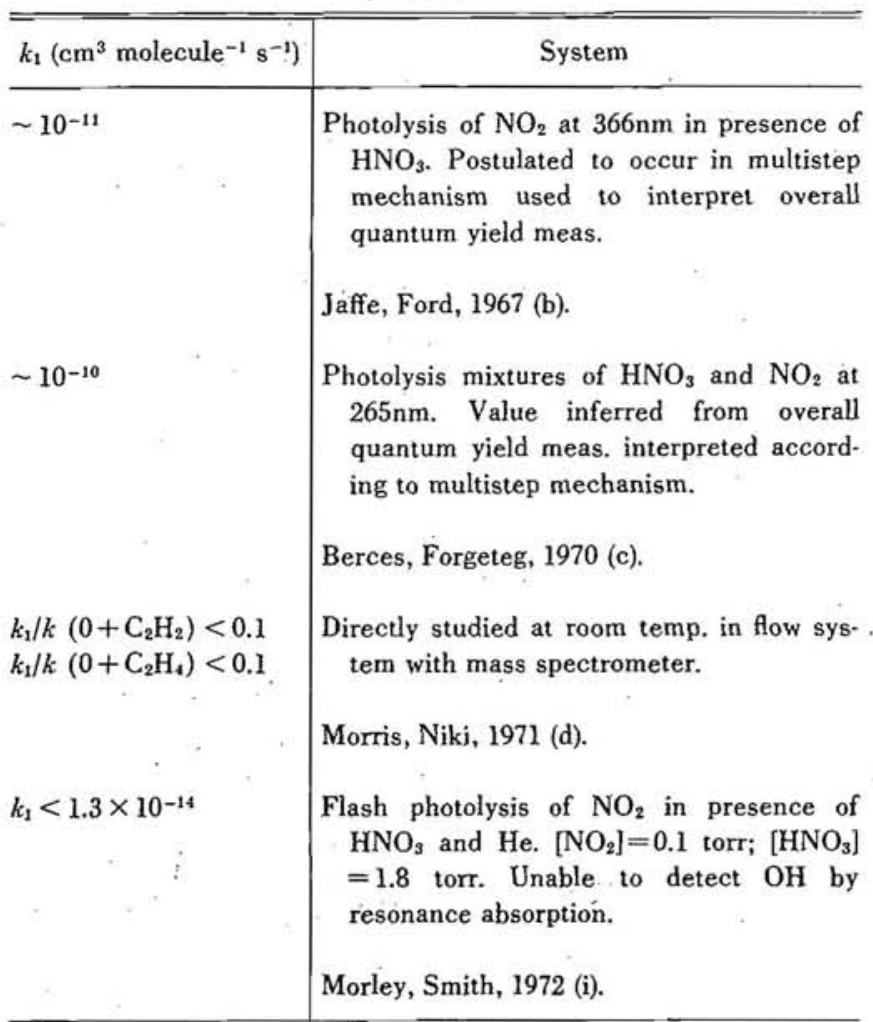

$$
\begin{gathered}
\text { Preferred Value } \\
k_{1}(298 \mathrm{~K}) \leqslant 1.5 \times 10^{-14} \mathrm{~cm}^{3} \text { molecule }{ }^{-1} \mathrm{~s}^{-1} . \\
\text { Remarks }
\end{gathered}
$$

The only direct study is that of Morris and Niki (d). Under the experimental conditions [O] $\sim 10^{14}$ molecule $\mathrm{cm}^{-3},\left[\mathrm{HNO}_{3}\right] \sim 10^{12}$ molecule $\mathrm{cm}^{-3}$, reaction time as great as $20 \mathrm{~ms}$, little or no change in the $\mathrm{HNO}_{3}$ concentration was observed as monitored by the m/e 46 peak. Comparison with the rate of loss of ethylene and acetylene under identical conditions led to the eonclusion that the rate constant $k_{1}$ was at least 10 times $k_{1} \quad$ smaller than the rate constants for the reactions of atomic oxygen with either ethylene or acetylene. The rate constant for the reaction of atomic oxygen with acetylene (which is slower than the corresponding ethylene reaction) is $1.5 \times 10^{-13} \mathrm{~cm}^{3}$ molecule $^{-1}$ $\mathrm{s}^{-1}(\mathrm{e})(\mathrm{f})$, hence $k_{1} \leqslant 1.5 \times 10^{-14} \mathrm{~cm}^{3}$ molecule ${ }^{-1} \mathrm{~s}^{-1}$.

This limiting value is supported by the work of Morley and Smith (i) who produced $\mathrm{O}$ atoms by the photolysis of $\mathrm{NO}_{2}$ in a mixture of $\mathrm{HNO}_{3}$ and $\mathrm{He}$, and were unable to detect any $\mathrm{OH}$ by means of resonance absorption. They derived an upper limit to the rate constant $k_{1} \leqslant 1.3 \times 10^{-14} \mathrm{~cm}^{3}$ molecule ${ }^{-1} \mathrm{~s}^{-1}$.

Using a pulsed uv photolysis chemiluminescent technique under conditions of excess $\mathrm{HNO}_{3}$ Stuhl (in a private communication quoted in (d)) observes that $k_{1}$ is several orders of magnitude slower than inferred from the photolysis experiments at 366 and $265 \mathrm{~nm}$ (b) and (c).

Johnston (g) has argued that this discrepancy in $k_{1}$ is a consequence of unrecognized heterogenous reactions occurring, specifically $\mathrm{NO}+\mathrm{HNO}_{3}$, in the case of (b) and (c), citing the experience of Smith (h). The direct observations (d) are accepted. Note that there is an alternative path $\mathrm{O}+\mathrm{HNO}_{3} \rightarrow \mathrm{O}_{2}+\mathrm{HNO}_{2}$, $\Delta \mathrm{H}_{298}^{\circ}=-194 \mathrm{~kJ} / \mathrm{mol}(-46.3 \mathrm{kcal} / \mathrm{mol})(\mathrm{a})$.

\section{References}

(a) D. D. Wagman, et al., NBS Technical Note 270-3 (Jan. 1968). Data on $\mathrm{NO}_{3}$ from D. R. Stull and H. Prophet, JANAF Thermochemical Tables, 2d Ed., Nat. Stand. Ref. Data. Ser. Nat. Bur. Stand. (U.S.), 37 (June 1971).

(b) S. Jaffe and H. W. Ford, J. Phys. Chem. 71, 1832 (1967).

(c) T. Berces and S. Forgeteg, Trans. Faraday Soc. 66, 640 (1970).

(d) E. D. Morris, Jr. and H. Niki, J. Phys. Chem. 75, 3193 (1971).

(e) K. Hoyerman, H. Gg. Wagner, and J. Wolfrum, Z. Physik, Chem. (Frankfurt) 63, 193 (1969).

(f) A. A. Westenberg and N. De Haas, J. Phys. Chem. 73, 1181 (1969).

(g) H. Johnston, Formation and Stability of Nitric Acid in the Strato. sphere, typescript, University of California, Berkeley, California (1971).

(h) J. H. Smith, J. Am. Chem. Soc. 69, 1741 (1947).

(i) C. Morley and I. W. M. Smith, J. Chem. Soc. Faraday Trans. II, 68, 1016 (1972).

J. T. Herron, R. E. Huie

February, 1972

Revised: January, 1973

\subsection{The Reaction of $\mathrm{HO}$ with $\mathrm{H}_{2} \mathrm{O}_{2}$}

$$
\mathrm{HO}+\mathrm{H}_{2} \mathrm{O}_{2} \rightarrow \mathrm{HO}_{2}+\mathrm{H}_{2} \mathrm{O}
$$

Auxiliary Data

$\Delta H_{298}^{\circ}=-124.3 \mathrm{~kJ} \mathrm{~mol}^{-1}\left(-29.7 \mathrm{kcal} \mathrm{mol}^{-1}\right)$

$\log _{10} K_{\mathrm{eq}}=-0.329+6.612(1000 / \mathrm{T})$

$$
\text { Data }
$$

The available data prior to 1972 have been described $k_{1} \quad$ and evaluated by Baulch et al. (h) and by Drysdale and Lloyd (i).

Upper and lower limits for $k_{1}$ at $298 \mathrm{~K}$ have been derived from studies employing flash photolysis (b) and electric discharge (c) of $\mathrm{H}_{2} \mathrm{O}_{2}$.

Absolute values of $k_{1}$ over the temperature range $307-462 \mathrm{~K}$ have been determined in flash photolysis studies by following the $\mathrm{OH}$ decay by kinetic spectroscopy. 
Rate ratio data at higher temperatures extends the range. A $k_{1} / k_{2}$ ratio was determined at $798 \mathrm{~K}$ using the thermal decomposition of $\mathrm{H}_{2} \mathrm{O}_{2}$ in the presence $\mathrm{CO}$ (d).

$$
\mathrm{CO}+\mathrm{HO} \rightarrow \mathrm{CO}_{2}+\mathrm{H}
$$

The rate relative to reaction (3),

$$
\mathrm{HO}+\mathrm{H}_{2} \rightarrow \mathrm{H}+\mathrm{H}_{2} \mathrm{O}
$$

has been determined between 700 and $800 \mathrm{~K}$ by examination of the inhibition of the second explosion limit of the $\mathrm{H}_{2} / \mathrm{O}_{2}$ system by $\mathrm{H}_{2} \mathrm{O}_{2}$ (e), in studies of the decomposition of $\mathrm{H}_{2} \mathrm{O}_{2}$ in the presence of $\mathrm{H}_{2}$ in boric acid coated vessels (f) and from studies of the $\mathrm{H}_{2} / \mathrm{O}_{2} / \mathrm{N}_{2}$ system (g).

\section{Recent Measurements}

There has been only one measurement involving the rate of this reaction since the 1972 review by Baulch, et al. (h).

\begin{tabular}{c|c}
\hline \hline Quantity measured & \multicolumn{1}{c}{ System } \\
\hline$k_{1} / k_{2}=8.13 \pm 0.56$ & Photolysis of $\mathrm{H}_{2} \mathrm{O}_{2}(0.94$ torr) at \\
where $k_{2}: \mathrm{HO}+\mathrm{CO} \rightarrow$ & $254 \mathrm{~nm}$ in presence of $\mathrm{O}_{2}(5.4$ \\
$\mathrm{CO}_{2}+\mathrm{H}$ & torr) and $\mathrm{CO}(3-32$ torr $)$. \\
& Measured initial rate of \\
& formation of $\mathrm{CO}_{2}$. \\
& Gorse, Volman, $1972(\mathrm{k})$. \\
\hline
\end{tabular}

\section{Preferred Value}

$k_{1}=1.7 \times 10^{-11} \exp (-910 / T) \mathrm{cm}^{3}$ molecule ${ }^{-1} \mathrm{~s}^{-1}$ for $298<T<800$.

$k_{1}(300 \mathrm{~K})=8.2 \times 10^{-13} \mathrm{~cm}^{3}$ molecule $\mathrm{e}^{-1} \mathrm{~s}^{-1}$. This is the evaluation given in refs. $(h, i)$. It fits the measured data within 50 percent.

\section{Remarks}

Reaction $\mathrm{l}$ is a simple $\mathrm{H}$ atom abstraction

$$
\mathrm{HO}+\mathrm{H}-\mathrm{O}_{2} \mathrm{H} \rightarrow \mathrm{H}_{2} \mathrm{O}+\mathrm{HO}_{2},
$$

and is the only interaction expected in this system. The evaluation relies heavily on the data of Greiner which are the only absolute rate measurements available. The flash photolysis study is subject to some uncertainty due to the method of temperature measurement. The temperature was varied by changing inert gas pressures thereby lowering the effect of flash heating. This coupled with the normal experimental uncertainties gives a reliability factor of approximately 2 to the data. Thus, the expression given above probably predicts the value for $k_{1}$ within a factor of 2 over the temperature range 298 to $800 \mathrm{~K}$. At stratospheric temperatures $200-240 \mathrm{~K}$ the uncertainty is considerably larger (probably at least a factor of 4). Thus a number of lower temperature measurements are in order.

A value of $k_{1}$ can be derived from the recent relative rate measurement in ref. (k) by selecting a value for $k_{2}$ : $\mathrm{HO}+\mathrm{CO} \rightarrow \mathrm{CO}_{2}+\mathrm{H}$. We select as the best value for $k_{2}$ that recently measured directly by Stuhl and Niki (1): $k_{2}=1.35 \times 10^{-13} \mathrm{~cm}^{3}$ molecule ${ }^{-1} \mathrm{~s}^{-1}$. Using this value, we derive the value $k_{1}=(11 \pm 3) \times 10^{-13} \mathrm{~cm}^{3}$ molecule ${ }^{-1} \mathrm{~s}^{-1}$ from the ratio measured in (k). We consider this to be in substantial agreement with the value $k_{1}$ $(300 \mathrm{~K})=8.2 \times 10^{-13} \mathrm{~cm}^{3}$ molecule ${ }^{-1} \mathrm{~s}^{-1}$ recommended in the Preferred Value section. The combined uncertainties in the measured values of $\left(k_{1} / k_{2}\right)$ and $k_{2}$ and the complexity of the mechanism used in $(k)$ do not justify changing the recommended value of $k_{1}$.

\section{References}

(a) D. R. Stull and H. Prophet, JANAF Thermochemical Tables, 2d. Ed., Nat. Stand. Ref. Data Ser., Nat. Bur. Stand. (U.S.), 37 (June 1971).

(b) N. R. Greiner, J. Chem. Phys. 45, 99 (1966); ibid, 46, 2450 (1967) (erratum); superseded by J. Phys. Chem. 72, 406 (1968).

(c) S. N. Foner and R. L. Hudson, J. Chem. Phys. 36, 2681 (1962).

(d) D. E. Hoare, Proc. Roy. Soc. (London) A291, 73 (1966).

(e) W. Forst and P. A. Giguere, J. Phys. Chem. 62, 340 (1958), R. R. Baldwin and L. Mayor, Trans. Faraday Soc. 56, 80 and 103 (1960), R. R. Baldwin, P. Doran, and L. Mayor, Symp. Combust 8 th, 103 (1962).

(f) R. R. Baldwin and D. Brattan, Symp. Combust 8th, 110 (1962), R. R. Baldwin, D. Jackson, R. W. Walker, and S. J. Webster, Symp. Combust 10th, 423 (1965).

(g) R. R. Baldwin, D. Jackson, R. W. Walker, and S. J. Webster, Trans. Faraday Soc. 63, 1676 (1967).

(h) D. L. Baulch, D. D. Drysdale, D. G. Horne, A. C. Lloyd, Evaluated Kinetic Data for High Temperature Reactions volume 1, Homogeneous gas phase reactions of the $\mathrm{H}_{2}-\mathrm{O}_{2}$ system, Butterworth \& Co., London (1972); also in D. L. Baulch, D. D. Drysdale, and A. C. Lloyd, High Temperature Reaction Rate Data, Report No. 3 (1969), Dept. of Physical Chemistry, The University, Leeds, England.

(i) D. D. Drysdale and A. C. Lloyd, Oxidation and Combustion Reviews, 4, 157 (1970).

(j) V. N. Kondratiev, Rate Constants of Gas Phase ReactionsReference Book, R. M. Fristrom, editor. National Technical Information Service, Springfield, Virginia COM-72-10014 (Jan. 1972).

(k) R. A. Gorse and D. H. Volman, J. Photochem., 1, 1-10 (1972).

(l) F. Stuhl and H. Niki, J. Chem. Phys. 57,3671 (1972).

M. J. Kurylo

A. H. Laufer

W. Braun

July, 1972

Revised: January, 1973 
4.14. The Reaction of $\mathrm{HO}$ and $\mathrm{O}_{3}$

\begin{tabular}{l|c|cc}
\hline \hline & \multicolumn{2}{|c}{$\Delta H_{288}^{\circ}(\mathrm{a})$} \\
\cline { 2 - 4 } & $\mathrm{kJ} \mathrm{mol}-1$ & $\left(\mathrm{kcal} \mathrm{mol}^{-1}\right)$ \\
\hline $\mathrm{HO}+\mathrm{O}_{3} \rightarrow \mathrm{HO}_{2}+\mathrm{O}_{2}$ & $-160 \pm 8$ & $(-38 \pm 2)$ & $k_{\mathrm{a}}$ \\
$\mathrm{HO}+\mathrm{O}_{3} \rightarrow \mathrm{H}+2 \mathrm{O}_{2}$ & +36.4 & $(+8.7)$ & $k_{1 \mathrm{~b}}$ \\
$\mathrm{HO}+\mathrm{O}_{3} \rightarrow \mathrm{HO}+\mathrm{O}_{2}+\mathrm{O}$ & 106.3 & $(25.4)$ & $k_{\mathrm{c}}$ \\
$\mathrm{HO}++\mathrm{O}_{3} \rightarrow$ all channels & & & $k_{1} \dagger$ \\
\hline
\end{tabular}

${ }^{\dagger}$ A dagger following a formula or reaction number, e.g. $\mathrm{HO}^{\dagger}$, $k_{1}^{\dagger}$, means vibrational excitation.

$k_{1}=k_{1 \mathrm{a}}+k_{1 \mathrm{~b}}+k_{1 \mathrm{c}}$

\section{Auxiliary Data}

Excitation energy of $\mathrm{HO}$ in vibrational levels $1-9$ of the ground state. No rotational energy included (b).

\begin{tabular}{c|c|c||c|c|c}
\hline$v$ & $\mathrm{~kJ} \mathrm{~mol}^{-1}$ & $\mathrm{kcal} \mathrm{mol}^{-1}$ & $v$ & $\mathrm{~kJ} \mathrm{~mol}^{-1}$ & $\mathrm{kcal} \mathrm{mol}^{-1}$ \\
\hline 0 & 0.0 & 0.0 & 5 & 193.9 & 46.3 \\
1 & 42.7 & 10.2 & 6 & 226.8 & 54.2 \\
2 & 83.4 & 19.9 & 7 & 257.7 & 61.6 \\
3 & 122.2 & 29.2 & 8 & 286.6 & 68.5 \\
4 & 159.0 & 38.0 & 9 & 313.4 & 74.9 \\
\hline
\end{tabular}

Subtract (add) values above to $\Delta H$ of reaction if $H \mathrm{O}$ is a reactant (product) to obtain $\Delta H$ for $H O$ in a specific level.

$\Delta H f_{298}^{\circ}(\mathrm{HO})=39.0 \mathrm{~kJ} \mathrm{~mol}^{-1}\left(9.31 \mathrm{kcal} \mathrm{mol}^{-1}\right)(\mathrm{a})$.

Closely related reactions

\begin{tabular}{l|c|ll}
\hline \hline & $\mathrm{kJ} \mathrm{mol}^{-1}$ & $(\mathrm{kcal} \mathrm{mol}-1)$ \\
\hline $\mathrm{HO}+\mathrm{H}_{2} \rightarrow \mathrm{H}_{2} \mathrm{O}+\mathrm{H}$ & -62.8 & $(-15.0)$ & $k_{2}$ \\
$\mathrm{HO}\left(v^{\prime}\right)+\mathrm{M} \rightarrow \mathrm{HO}\left(v^{\prime \prime}\right)+\mathrm{M}$ & & & $k_{3}$ \\
$\mathrm{HO}+\mathrm{H}_{2} \mathrm{O}_{2} \rightarrow \mathrm{HO}_{2}+\mathrm{H}_{2} \mathrm{O}$ & $-125 \pm 8$ & $(-30 \pm 2)$ & $k_{4}$ \\
$\mathrm{HO}+\mathrm{O} \rightarrow \mathrm{H}+\mathrm{O}_{2}$ & -70.3 & $(-16.8)$ & $k_{5}$ \\
$\mathrm{H}+\mathrm{O}_{3} \rightarrow \mathrm{HO}+\mathrm{O}_{2}$ & $-32 \mathrm{I} .7$ & $(-76.9)$ & $k_{6}$ \\
$\mathrm{HO}_{2}+\mathrm{O}_{3} \rightarrow \mathrm{HO}+2 \mathrm{O}_{2}$ & $-125 \pm 8$ & $(-30 \pm 2)$ & $k_{7}$ \\
\hline
\end{tabular}

Data

Measurements

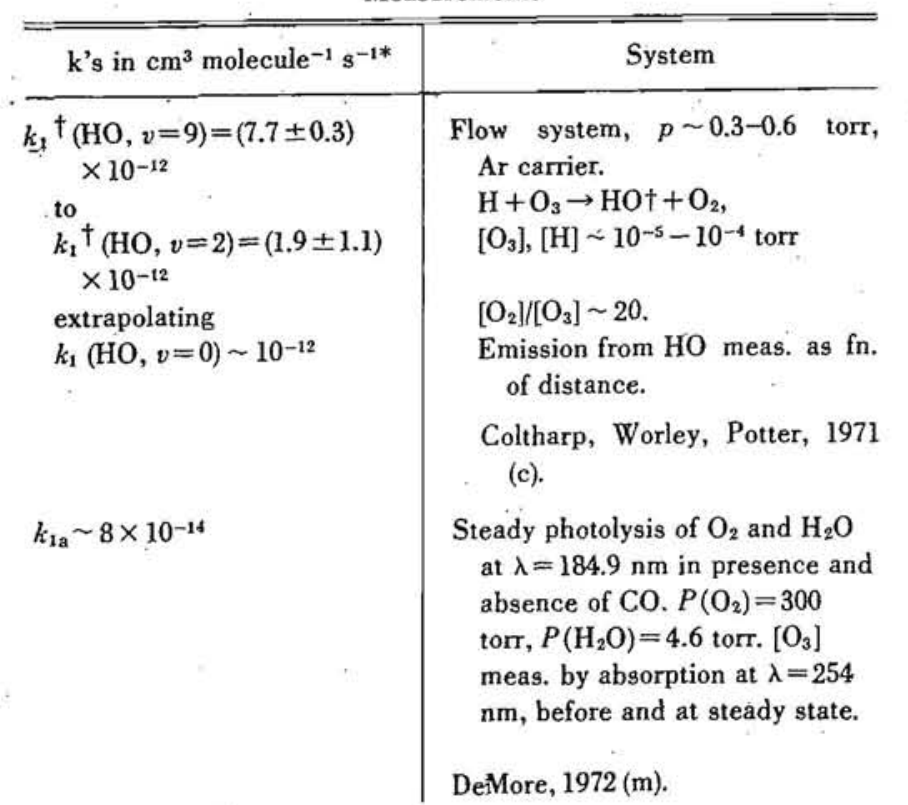

Measurements-Continued

\begin{tabular}{c|c}
\hline \hline k's in $\mathrm{cm}^{3}$ molecule $\mathrm{s}^{-1} \mathrm{~s}^{-1 *}$ & \multicolumn{1}{c}{ System } \\
\hline$k_{1 \mathrm{a}}=(5.5 \pm 1.5) \times 10^{-14}$ & Fast flow reactor, $[\mathrm{HO}] \sim 3 \times 10^{11}$, \\
at $298 \mathrm{~K}$ & {$\left[\mathrm{O}_{3}\right]=1-6 \times 10^{14}$ molecules $\mathrm{cm}^{-3}$,} \\
$E / R=0.96 \times 10^{3}$ & added He to make $P($ total $)=$ \\
$220<T<450 \mathrm{~K}$ & $2-5.5$ torr. $[\mathrm{HO}]$ vs distance \\
& measured by resonance \\
& fluorescence at $\lambda=309 \mathrm{~nm},\left[\mathrm{O}_{3}\right]$ \\
& meas. by absorption at $\lambda=254$ \\
& nm. HO from $\mathrm{H}+\mathrm{NO}_{2} \rightarrow \mathrm{HO}+$ \\
& NO.
\end{tabular}

Anderson, Kaufman, 1973 (p).

$k_{1 \mathrm{a}} / k_{\mathrm{i}}=1 / 12$

See remarks.

Photolysis of $\mathrm{O}_{3}, \lambda=254 \mathrm{~nm}$ in the presence of $\mathrm{H}_{2} \mathrm{O}_{2}$ in a flow system, 25 to $100^{\circ} \mathrm{C}$.

$\left[\mathrm{O}_{3}\right] /\left[\mathrm{H}_{2} \mathrm{O}_{2}\right]=0.7$ to $10,\left[\mathrm{O}_{3}\right]=$ (2.7 to 15$) \times 10^{-8} \mathrm{~mol} \mathrm{~cm} \mathrm{~cm}^{-3},\left[\mathrm{O}_{2}\right]$ to make up a total pressure of I atm, $\left(4 \times 10^{-5} \mathrm{~mol} / \mathrm{cm}^{3}\right)$ $\Delta \mathrm{O}_{3} / \Delta t, \Delta \mathrm{H}_{2} \mathrm{O}_{2} / \Delta t$ meas.

Volman, 1951 (j).

$k_{1 \mathrm{a}}=7 \times 10^{-14}$
See remarks.

From data of ref. (j) and an evaluation of $k_{4}=0.16 \times 10^{-10}$ $\exp \left(-0.9 \times 10^{3} / T\right)$.

Drysdale, Lloyd, 1970 (k).

Estimates

\begin{tabular}{l|l}
\hline$k_{1}<5 \times 10^{-13}$ & Flow systems, $p \sim 1$ torr.
\end{tabular}

$\mathrm{H}+\mathrm{NO}_{2} \rightarrow \mathrm{HO}+\mathrm{NO}$.

$\Delta[\mathrm{HO}] / \Delta t$ meas. in presence and absence of $\mathrm{O}_{3}$.

Kaufman, 1964 (f).

$k_{1}$, no reaction $k_{1} t k_{2}{ }^{\dagger}>10^{3}$

$k_{1 \mathrm{a}}<10^{-16}$

$k_{1 \mathrm{a}}>10^{-16}$

*At room temperature unless otherwise indicated.
Liquid phase, photolysis of $\mathrm{O}_{3}$, $\lambda=254 \mathrm{~nm}$, in $\mathrm{H}_{2} / \mathrm{O}_{3} / \mathrm{Ar}$ solutions at $87 \mathrm{~K} . \phi\left(\mathrm{O}_{3}\right)$ meas. in presence and absence of added $\mathrm{O}_{2} \cdot \mathrm{H}_{2} / \mathrm{O}_{3} \sim 200$.

DeMore, 1967 (g.)

Flash photolysis of $\mathrm{O}_{3} / \mathrm{H}_{2} \mathrm{O} / \mathrm{Ar}$ mixtures. $\left[\mathrm{O}_{3}\right]=1$ torr, $\left[\mathrm{H}_{2} \mathrm{O}\right]=$ $1,5,10$ torr, $[\mathrm{Ar}]=100$ torr. $\Delta \mathrm{O}_{3} / \Delta t$ meas. $\Delta \mathrm{O}_{3} / \Delta t$ decreases as $\left[\mathrm{H}_{2} \mathrm{O}\right]$ increases.

Langley, McGrath, 1971 (h).

Estimate based on interpretation of quantum yields in the photolysis of $\mathrm{O}_{3}$ in the presence of water in terms of chain: reactions (1) and (7).

Johnston, 1968 (i). 
Preferred Values

(Changed from that in NBS Report 10828 (April 1972).)

$k_{1 \mathrm{a}}=1.6 \times 10^{-12} \exp \left(-1 \times 10^{3 / T}\right) \mathrm{cm}^{3}$ molecule ${ }^{-1} \mathrm{~s}^{-1}$. $220<T<450 \mathrm{~K}, \log k \pm 0.3$.

$k_{1 \mathrm{a}}=6 \times 10^{-14}$ at $300 \mathrm{~K}$.

The results in reference (c) may be used as an upper limit for reaction $\left(1^{\dagger}\right)$.

$k_{1}^{\dagger}(\mathrm{HO}, v=9)<7.7 \times 10^{-12} \mathrm{~cm}^{3}$ molecule $\mathrm{e}^{-1} \mathrm{~s}^{-1}$.

This is a sum over all channels, not an elementary process. There are no data on reactions (lb) and (lc).

Remarks

The preferred value is approximately that from the current experiments of Anderson. These are the most direct measurements of $k_{\mathrm{ia}}$ and are preferred for that reason. The error limit is broad, and reflects the disagreement between reference (p) and the only other recent quantitative measurement, reference (m). The earlier quantitative result (j) has been reinterpreted to exclude reaction (la). All of the earlier limit estimates should now be disregarded. Reaction (la) should be considered an $\mathrm{O}$-atom transfer reaction with a normal rate constant.

DeMore's steady state photolysis experiments (ref. m) yield an approximate value that is fifty percent larger than reported in (p). This is good agreement if the very different technique and greater complexity of the experimental system are considered.

More experiments on reaction (1a) are needed in order to establish the value and narrow the error bounds. A rate constant of this magnitude makes reaction (1) an important component of mechanisms of stratospheric chemistry.

DeMore's work $(m)$ is especially important for an understanding of the $\mathrm{O}_{3} / \mathrm{HO}_{\mathbf{x}}$ system. It has been evident since the studies of Forbes and Heidt in the early 1930's (q) that there is a chain reaction sequence involving $\mathrm{HO}_{\mathrm{x}}$ that destroys ozone. The simplest chain is that proposed by Norrish and Wayne (r)

$$
\begin{aligned}
& \mathrm{HO}+\mathrm{O}_{3} \rightarrow \mathrm{HO}_{2}+\mathrm{O}_{2} \\
& \mathrm{HO}_{2}+\mathrm{O}_{3} \rightarrow \mathrm{HO}+2 \mathrm{O}_{2}
\end{aligned}
$$

Most studies of the $\mathrm{O}_{3} / \mathrm{HO}_{\mathrm{x}}$ system have used high $\left[\mathrm{O}_{3}\right] /\left[\mathrm{O}_{2}\right]$ ratios and photolysis of $\mathrm{O}_{3}$ of wavelengths less than $300 \mathrm{~nm}$. Energy transfer steps and reactions of electronically excited $\mathrm{O}$ and $\mathrm{O}_{2}$ could not be ruled out. DeMore's experiments, in which $\mathrm{O}\left({ }^{3} P\right)$ alone is formed and in which there is a high $\left[\mathrm{O}_{2} \mathrm{y} /\left[\mathrm{O}_{3}\right]\right.$ ratio indicate that the chain must involve only normal (thermally equilibrated) species.
Under his experimental conditions reaction (7) is the most likely step regenerating hydroxyl. The occurence of this reaction has been questioned, because it is difficult to formulate a transition state. The reaction could be an $\mathrm{O}$-atom transfer followed by rapid decomposition of an unstable $\mathrm{O}_{4}$ complex. Unfortunately, analogous processes cannot be cited. The systems in which the $\mathrm{O}_{3} / \mathrm{HO}_{\mathrm{x}}$ chain have been studied are complex. They require elaborate mechanisms for complete interpretation. Thus the importance of reaction (7), although probable, is not firmly established. Experiments are needed in which other species than $\mathrm{O}_{3}$ are measured.

Comments on specific studies follow.

Ref. (c)

The total rate of reaction of $\mathrm{HO}(v=2$ to 9$)$ in the presence of $\mathrm{O}_{3}$ was measured. This is based on infrared emission bands. Corrections were made for loss by radiation and at the walls. Both corrections are large. Physical quenching appears to be minor (d). Thus, these rates are summations for the chemical reactions in the system.

When extrapolated to HO $(v=0), k_{1} \sim 10^{-12}$, in reasonable agreement with the experiments in (p), since the extrapolation presupposes no energy barrier. This extrapolation depends heavily on the radiative life time for $\mathrm{HO}(v=9), \tau_{9}=6.4 \times 10^{-2} \mathrm{~s}$, and on the relative transition probabilities for the lower states. $\tau_{9}$ is surprisingly long.

The experiments are extensive, but are not described in sufficient detail to permit estimates of concentrations in the measurement region of the flow tube. As is the case with most studies of secondary reactions, the measured phenomenon occurs in a region where there is a buildup of product. For $\mathrm{HO}(v=9), 50$ percent of reaction $\left(1^{\dagger}\right)$ must have occurred before the earliest measurement. Water is an effective quencher (e) and may be troublesome. So might reaction with $\mathrm{H}_{2}$ (reaction $\left(2^{\dagger}\right)$ although DeMore's data suggest this is not important $(\mathrm{g})$. Experiments in the absence of excess $\mathrm{O}_{3}$ would be desirable to test this point and to determine the "background" decay rate. Direct, optical, measurements of $\left[\mathrm{O}_{3}\right]$ also are needed.

\section{Ref. $(f)$}

This upper limit is based on the absence of an effect of $\mathrm{O}_{3}$ on the rate of disappearance of $\mathrm{HO}$ and on an estimate of instrumental sensitivity.

Ref. (g)

Absence of a reaction of thermal $\mathrm{HO}$ at $87 \mathrm{~K}$ does not rule out a gas phase reaction at room temperature if there is an activation energy. However, the experiments suggest that it will be slow. 
The two results (no reaction of thermal $\mathrm{HO}$, reaction of excited $\mathrm{OH}$ ) are based on quantum yields of $\mathrm{O}_{3}$ destruction and water formation in the presence and absence of small additions of $\mathrm{O}_{2}$. The pertinent reactions are:

$$
\begin{aligned}
\mathrm{O}_{3}+h \nu & \rightarrow \mathrm{O}\left({ }^{1} D\right)+\mathrm{O}_{2} \\
\mathrm{O}\left({ }^{1} D\right)+\mathrm{H}_{2} & \rightarrow \mathrm{H}+\mathrm{HO} \\
\mathrm{H}+\mathrm{O}_{2}+\mathrm{M} & \rightarrow \mathrm{HO}_{2}+\mathrm{M} \\
\mathrm{HO}+\mathrm{O}_{3} & \rightarrow \mathrm{HO}_{2}+\mathrm{O}_{2} \\
\mathrm{HO}_{2}+\mathrm{O}_{3} & \rightarrow \mathrm{HO}^{\dagger}+\mathrm{O}_{2} \\
\mathrm{H}+\mathrm{O}_{3} & \rightarrow \mathrm{HO}^{\dagger}+\mathrm{O}_{2} \\
\mathrm{HO}^{\dagger}+\mathrm{O}_{3} & \rightarrow \mathrm{H}+2 \mathrm{O}_{2}
\end{aligned}
$$

The interpretation, which we accept, may be summarized as follows. In the presence of $\mathrm{O}_{2}$, reaction (8) scavenges $\mathrm{H}$ atoms. Then $\Delta \mathrm{O}_{3}=\Delta \mathrm{H}_{2} \mathrm{O}$ where water is the ultimate product formed from radicals and peroxides in the system. This is interpreted to mean that reactions (la) and (7) do not occur, i.e., $\mathrm{HO}$ and $\mathrm{HO}_{2}$ are unreactive. In the absence of sufficient $\mathrm{O}_{2}$ to scavenge $\mathrm{H}$ atoms, $\Delta \mathrm{O}_{3}>\Delta \mathrm{H}_{2} \mathrm{O}$. This is interpreted as due to the chain (6) followed by some reaction of $\mathrm{HO}^{\dagger}$ with $\mathrm{O}_{3}$. The chain (6) and $\left(1 \mathrm{~b}^{\dagger}\right)$ is favored over (6), $\left(1 \mathrm{a}^{\dagger}\right)$, and (7) because (7) is ruled out by the experiments with added $\mathrm{O}_{2}$.

\section{Ref. $(h)$}

A preliminary report on flash photolysis experiments. Details not given. No evidence was found for a chain reaction in a system containing $\mathrm{O}_{3}$ and $\mathrm{HO}$, either immediately or at long times after the flash. Hydroxyl is formed in the sequence

$$
\begin{aligned}
& \mathrm{O}_{3}+h \nu \rightarrow \mathrm{O}\left({ }^{1} D\right)+\mathrm{O}_{2}\left({ }^{1} \Delta\right) \\
& \mathrm{O}\left({ }^{1} D\right)+\mathrm{H}_{2} \mathrm{O} \rightarrow \mathrm{HO}+\mathrm{HO}
\end{aligned}
$$

with little, if any excitation of the HO. At short times the quantum yield, $\phi\left(-\mathrm{O}_{3}\right)$, is $\sim 2$. This is in contrast to the steady photolysis of $\mathrm{O}_{3} / \mathrm{H}_{2} \mathrm{O}$ mixtures in which high quantum yields are found: $\left(\Phi\left(-\mathrm{O}_{3}\right)\right.$ up to 100$)$. The authors argue that their results rule out reactions (la) and (7) in both types of photolysis. The upper limit is based on absence of an effect and an estimate of instrumental sensitivity. Fortin, et al. (o) have criticized the interpretation given in ref. (h). They studied the flash photolysis of moist ozone, show that a very extensive mechanism must be used to interpret the intermediate quantum yield, and state that reactions (1a) and (7) would contribute very little even if both had rate constants $\sim 5 \times 10^{-13} \mathrm{~cm}^{3}$ molecule ${ }^{-1} \mathrm{~s}^{-1}$.

Ref. (i)

This lower limit estimate is based on the chain mechanism $(\mathrm{la}, 7)$ and on an estimate of $\left[\mathrm{HO}_{2}\right]$. The estimate is too indirect to be useful.

Refs. ( $j$ and $k$ )

These data were, prior to 1972 , the only quantitative measurements on reaction (la). Volman has recently reexamined and reinterpreted them (n) in the light of the now known kinetics of reactions of $\mathrm{O}\left({ }^{1} D\right)$. He concludes that reaction (la) is probably not important, but that

$$
\mathrm{O}\left({ }^{1} D\right)+\mathrm{H}_{2} \mathrm{O}_{2} \rightarrow \mathrm{HO}+\mathrm{HO}_{2} \quad k_{10}
$$

controls the variation of $\Delta\left[\mathrm{O}_{3}\right] / \Delta\left[\mathrm{H}_{2} \mathrm{O}_{2}\right]$ with reactant concentrations. The rate constant $k_{10}$ may be up to 10 fold faster than $\mathrm{O}\left({ }^{1} \mathrm{D}\right)+\mathrm{H}_{2} \mathrm{O}$, that is, it occurs essentially at every collision.

We agree with the reinterpretation but also note that we have been unable to model these experiments using modern rate data to the point that the observed concentration changes can be reproduced. The modelling gives smaller $\mathrm{O}_{3}$ and $\mathrm{H}_{2} \mathrm{O}_{2}$ destruction.

These experiments remain important for interpretation of the $\mathrm{O}_{3}$ photolysis in the presence of water. Volman gives evidence that there is no chain process. This is contrary to the results in reference (m). The two studies are sufficiently similar that they should agree on the point. We have no explanation.

Ref. $(m)$

Steady photolysis of $\mathrm{O}_{2}$ and $\mathrm{H}_{2} \mathrm{O}$ at $\lambda=184.9 \mathrm{~nm}$ in excess $\mathrm{O}_{2}$ produces $\mathrm{O}_{3}, \mathrm{HO}$, and $\mathrm{HO}_{2}$

$$
\begin{aligned}
\mathrm{O}_{2}+h \nu & \rightarrow 2 \mathrm{O} \\
\mathrm{O}+\mathrm{O}_{2}+\mathrm{M} & \rightarrow \mathrm{O}_{3}+\mathrm{M} \\
\mathrm{H}_{2} \mathrm{O}+h \nu & \rightarrow \mathrm{H}+\mathrm{HO} \\
\mathrm{H}+\mathrm{O}_{2}+\mathrm{M} & \rightarrow \mathrm{HO}_{2}+\mathrm{M}
\end{aligned}
$$

Photon absorption in this optically thick system was determined from rate of $\mathrm{O}_{3}$ formation in calibration experiments. Only slight $\mathrm{O}_{3}$ photolysis occurs. Rate of $\mathrm{O}_{2}$ photolysis is 9 fold greater than that of $\mathrm{H}_{2} \mathrm{O}$ for $P\left(\mathrm{O}_{2}\right)=300$ torr and $P\left(\mathrm{H}_{2} \mathrm{O}\right)=4.6$ torr. A steady state in $\mathrm{O}_{3}$ is reached at long times (more than $100 \mathrm{~min}$ ) that indicates chain destruction of $\mathrm{O}_{3}$ by $\mathrm{HO}$ and $\mathrm{HO}_{2}$. Interpreted as

$$
\begin{aligned}
\mathrm{HO}+\mathrm{O}_{3} & \rightarrow \mathrm{HO}_{2}+\mathrm{O}_{2}, \\
\mathrm{HO}_{2}+\mathrm{O}_{3} & \rightarrow \mathrm{HO}+2 \mathrm{O}_{2} .
\end{aligned}
$$

Competition experiments with added $\mathrm{CO}$ (removing $\mathrm{HO}$ and forming $\mathrm{HO}_{2}$ )

$$
\mathrm{CO}+\mathrm{HO} \rightarrow \mathrm{CO}_{2}+\mathrm{H},
$$

were used to obtain approximate values $k_{1 \mathrm{a}} \sim 8 \times 10^{-14}$ and $k_{7} \sim 3 \times 10^{-15} \mathrm{~cm}^{3}$ molecule $\mathrm{e}^{-1} \mathrm{~s}^{-1}$. These are only 
approximate because the system is optically thick and the concentrations of intermediates are intensity dependent.

$\operatorname{Ref.}(p)$

These experiments measure the total rate of disappearance of $\mathrm{HO}$ in the presence of excess $\mathrm{O}_{3}$. The method is similar to that used by the same authors for studying the reaction of $\mathrm{HO}$ with $\mathrm{NO}_{2}(\mathrm{~s})$. Tests indicated no measurable concentration of $\mathrm{O}$ atoms. The hydroxyl radicals used should be almost exclusively $\mathrm{HO}(v=0)$. The pre-exponential factor is $\sim 10^{-12} \mathrm{~cm}^{3}$ molecule $^{-1}$ $\mathrm{s}^{-1}$ which is consistent with the extrapolated value from reference (c).

These are the most direct measurements, to date, of $k_{1}$. Interference from $\mathrm{HO}_{2}+\mathrm{O}_{3}$ or $\mathrm{NO}+\mathrm{O}_{3}$ should be unimportant.

\section{Acknowledgement}

Drs. W. B. DeMore and J. Anderson have assisted us by providing information on experiments prior to publication. Discussions with Dr. D. H. Volman -about his work and DeMore's have been invaluable in the preparation of this report.

\section{References}

(a) D. D. Wagman, et al., NBS Tech. Note 270-3 (Jan. 1968).

(b) R. C. Herman and G. A. Hornbeck, Astrophys. J. 118, 214 (1953); A. M. Bass and D. Garvin, J. Molec. Spectr. 9, 114 (1962). (c) R. N. Coltharp, S. D. Worley, and A. E. Potter, Appl Optics 10, 1786 (1971); A. E. Potter, R. N. Coltharp, and S. D. Worley, J. Chem. Phys. 54, 992 (1971).

(d) S. D. Worley, R. N. Coltharp, and A. E. Potter, J. Chem. Phys. 55, 2608 (1971); R. N. Coltharp, S. D. Worley, and A. E. Potter, Am. Chem. Soc. 162d Nat. Meeting, Phys. Chem. Paper No. 89 (W ashington, Sept. 1971) preprint.

(e) S. D. Worley, R: N. Coltharp, and A. E. Potter, J. Phys. Chem. 76, 1511 (1972).

(f) F. Kaufman, Annales de Geophys. 20, 106 (1964).

(g) W. B. DeMore, J. Chem. Phys. 47, 2777 (1967); 46, 813 (1967).

(h) K. F. Langley and W. D. McGrath, Planet. Space Sci. 19, 413 (1971).

(i) H. S. Johnston, Nat. Stand. Ref. Data Ser., Nat. Bur. Stand. 20 (1968) footnote 3.

(j) D. H. Volman, J. Am. Chem. Soc. 73, 1018 (1951).

(k) D. D. Drysdale and A. C. Lloyd, Oxidn. and Comb. Rev. 4, 157 (1970).

(l) E. A. Albers, K. Hoyermann, H. Gg. Wagner, and J. Wolfrum, Symp. Combustion (International) 13, 81 (1971).

(m) W. B. DeMore, Rate Constants for the Reactions of $\mathrm{OH}$ and $\mathrm{HO}_{2}$ with Ozone, typescript, Jet Propulsion Laboratory 1972, and related correspondence among W. DeMore, D. Volman, and D. Garvin (Nov. Dec. 1972).

(n) D. Volman; correspondence with D. Garvin (Aug.-Oct. 1972).

(o) C. J. Fortin, D. R. Snelling, and A. Tardif, Can. J. Chem. 50, 2748 (1972).

(p) J. Anderson and F. Kaufman, private communication (Jan. 1973).

(q) G. S. Forbes and L. J. Heidt, J. Am. Chem. Soc. 56, 1671 (1934).

(r) R. G. W. Norrish and R. P. Wayne, Proc. Roy. Soc. (London) A288, 361 (1965).

(s) J. G. Anderson and F. Kaufman, Chem. Phys. Lettrs 16, 375 (1972).

D. Garvin

February 1972

Revised: January 1973

\subsection{The Reaction of $\mathrm{HO}_{2}$ with $\mathrm{HO}_{2}$}

$\mathrm{HO}_{2}+\mathrm{HO}_{2} \rightarrow \mathrm{H}_{2} \mathrm{O}_{2}+\mathrm{O}_{2}$

\section{Auxiliary Data}

$\Delta H_{29 \ddot{\xi}}^{\circ}=-178 \pm 16 \mathrm{~kJ} / \mathrm{mol}(-42.6 \pm 4 \mathrm{kcal} / \mathrm{mol})$

\section{Preferred value}

(Changed from that in NBS Report 10828 (April 1972).

$k_{1}(300)=6 \times 10^{-12} \mathrm{~cm}^{3}$ molecule ${ }^{-1} \mathrm{~s}^{-1}$, estimated uncertainty: a factor of two.

$k_{1}=3 \times 10^{-11} \exp (-500 / T) \mathrm{cm}^{3}$ molecule $^{-1} \mathrm{~s}^{-1}$ $(300-1000 \mathrm{~K})$, estimated uncertainty is an order of magnitude at $1000 \mathrm{~K}$.

$$
-d\left[\mathrm{HO}_{2}\right] / d t=2 k_{1}\left[\mathrm{HO}_{2}\right]^{2} \text {. }
$$

\section{Remarks}

There are four studies, three of which $(b, c, i)$ indicate a rate constant in the range $0.3-1.0 \times 10^{-11}$. For this reason the other (d) is rejected. Only the two latest measurements $(b, i)$ need be considered. The techniques are sufficiently difficult and different so that the discrepancy in rates is not surprising. Paukert's rate (b) $k_{1}$

$3.6 \pm 0.5 \times 10^{-12}$

$3 \times 10^{-12}$

$1.1 \times 10^{-10}$
Data

\begin{tabular}{l|l}
\hline \hline$k_{1}(300 \mathrm{~K})\left(\mathrm{cm}^{3}\right.$ molecule $\left.{ }^{-1} \mathrm{~s}^{-1}\right)$ & System \\
\hline
\end{tabular}

Flash photolysis of $\mathrm{H}_{2} \mathrm{O} / \mathrm{O}_{2}$ mixtures in $\mathrm{H}_{2}, \mathrm{He}, \mathrm{Ar}$, tòtal pressure: $1 \mathrm{~atm}$. $\left[\mathrm{HO}_{2}\right]$ vs time measures.

Hochanadel; et al., 1972 (i).

Photolysis of $\mathrm{H}_{2} \mathrm{O}_{2}$. $\mathrm{HO}_{2}$ absorption measured.

Paukert, Johnston, 1972 (b).

Electrical discharge through $\mathrm{H}_{2} \mathrm{O}_{2} . \mathrm{HO}_{2}$ detected by mass spectrometry.

Foner, Hudson, 1962 (c).

$\mathrm{Hg}$ photosensitized hydrogenoxygen reaction 293-319 K. Measured temp. rise.

Burgess, Robb, 1957 (d). 
depends upon the absolute value of the absorption coefficient for $\mathrm{H}_{2} \mathrm{O}_{2}$, while Hochanadel's depends upon that for $\mathrm{HO}_{2}$. Both measured the extinction coefficient of $\mathrm{HO}_{2}$ at $210 \mathrm{~nm}$ in units of $\mathrm{dm}^{3} \mathrm{~mol}^{-1} \mathrm{~cm}^{-1}$ base 10 : 1200 (b), 1770 (i). If the former is correct then the rate constant in (i) should be reduced to $6.5 \times 10^{-12} . \mathrm{cm}^{3}$ molecule $\mathrm{e}^{-1} \mathrm{~s}^{-1}$. A similar argument may not be made to raise the rate in (b). That rate is based on $\epsilon\left(\mathrm{H}_{2} \mathrm{O}_{2}\right)$ at $200 \mathrm{~nm}$ reported in ref. (g). A value twice as large has also been reported $(\mathrm{h})$.

Because of the uncertainty in $\epsilon\left(\mathrm{HO}_{2}\right)$, we simply have averaged the two rates $(b, i)$, and have adopted the activation energy estimated by Lloyd (e). His room temperature rate constant is, however, $3.3 \times 10^{-12}$ based on (b) and (c).

\section{References}

(a) D. D. Wagman, et. al., NBS Technical Note 270-3 (Jan. 1968)

(b) T. T. Paukert and H. S. Johnston, J. Chem. Phys. 56, 2824 (1972)

(c) Foner, S. N., and Hudson, R. L., Adv. Chem. Series 36, 34 (1962)

(d) Burgess, R. H., and Robb, J. C., Chem. Soc. Spec. Publ. 9, 16: (1957).

(e) Lloyd, A. C., Evaluated and Estimated Kinetic Data for the Ga: Phase Reactions of the Hydroperoxyl Radical, National Burea of Standards Report 10447 (July 1971).

(f) D. L. Baulch, D. D. Drysdale, D. G. Horne, A. C. Lloyd, Evaluatec Kinetic Data for High Temperature Reactions volume 1, Homogeneous gas phase reactions of the $\mathrm{H}_{2} \cdot \mathrm{O}_{2}$ system, Butter worth \& Co., London (1972).

(g) R. B. Holt, C. K. McLane, and O. Oldenberg, J. Chem. Phys. 16. 225,638 (1948).

(h) M. Schürgers and K. H. Welge, Z. Naturforsch 23a, 1508 (1968).

(i) C. J. Hochanadel, J. A. Ghormley, and P. J. Ogren, J. Chem. Phys. 56, 4426 (1972).

D. Garvin, R. F. Hampson

June. 1972

\subsection{The Overall Reaction of $\mathrm{H}_{2} \mathrm{O}$, NO, and $\mathrm{NO}_{2}$}

$$
\mathrm{H}_{2} \mathrm{O}+\mathrm{NO}+\mathrm{NO}_{2} \rightarrow 2 \mathrm{HNO}_{2}
$$

\section{Auxiliary Data}

$\Delta H^{\circ}{ }_{298}=-40.6 \mathrm{~kJ} / \mathrm{mol}(-9.7 \mathrm{kcal} / \mathrm{mol})$

$\Delta G^{\circ}{ }_{298}=-1.34 \mathrm{~kJ} / \mathrm{mol}(-0.32 \mathrm{kcal} / \mathrm{mol})$

$K_{P}=1.7 \mathrm{~atm}^{-1}$ (value calculated from above value of $\left.\Delta G^{\circ}{ }^{\circ 98}\right)$

\section{Preferred Value}

No recommendation can be made for the value of the rate constant for the homogeneous gas-phase reaction of $\mathrm{H}_{2} \mathrm{O}$, NO, and $\mathrm{NO}_{2}$ since the only rate data reported (ref. (b) and (c)) refer to the heterogeneous reaction occurring on the vessel walls (see Remarks).

\section{Remarks}

All that can be said about the value of the homogeneous gas-phase reaction rate constant is that it must be less than the values in (b) and (c) which pertain to the dominant heterogeneous reaction. Therefore, for the rate expression

$$
-d P_{\mathrm{NO}_{2}} / d t=k P_{\mathrm{NO}} P_{\mathrm{NO}_{2}} P_{\mathrm{H}_{2} \mathrm{O}}^{2},
$$

an upper limiting value for the homogeneous gas-phase reaction rate constant is (from Graham and Tyler):

$$
k \leqslant 1.1 \times 10^{-55} \mathrm{~cm}^{9} \text { molecule }{ }^{-3} \mathrm{~s}^{-1}:
$$

(Changed from that in NBS Report 10692 (Jan. 1972).)

The following mechanism was considered in both studies: $k_{1}$.

)

There are no direct data on the rate of the homogeneous gas phase reaction between $\mathrm{H}_{2} \mathrm{O}, \mathrm{NO}$, and $\mathrm{NO}_{2}$.

However the following data on the rate of the heterogeneous reaction can be used to set an upper limit to the rate of the homogeneous reaction.

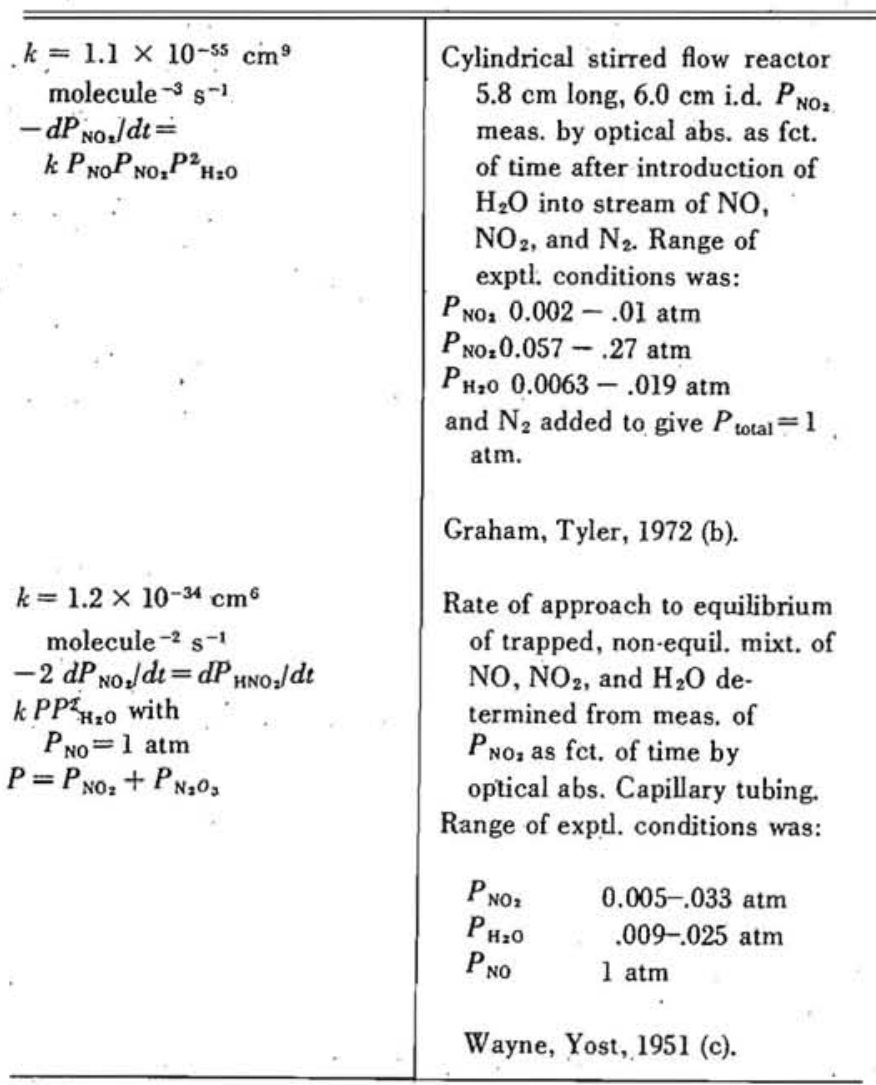




$$
\begin{aligned}
& \mathrm{NO}+\mathrm{NO}_{2}+\mathrm{H}_{2} \mathrm{O}=2 \mathrm{HNO}_{2} \\
& \mathrm{~N}_{2} \mathrm{O}_{3}+\mathrm{H}_{2} \mathrm{O}=2 \mathrm{HNO}_{2} \\
& \mathrm{NO}+\mathrm{NO}_{2}=\mathrm{N}_{2} \mathrm{O}_{3}
\end{aligned}
$$

Neither study distinguished between ( 1 ) and (2) because of the rapid attainment of equilibrium in (3).

\section{Remarks on Specific References}

Ref. (b)

This study verified the second-order dependence of the rate on $\left[\mathrm{H}_{2} \mathrm{O}\right]$ suggested in (c). A first-order dependence on $\left[\mathrm{NO}_{2}\right]$ and on [NO] was found. The surfaceto-volume ratio was $(1 / 40)$ the value in (c), and the rate constant was $(1 / 36)$ its value in (c) similarly defined. This strong dependence of $k$ on $(\mathrm{s} / \mathrm{v})$ was interpreted as evidence for the heterogeneous nature of the reaction. They attempted to fit the data to the stoichiometry indicated by eqn. (1), i.e. first order in $\mathrm{H}_{2} \mathrm{O}, \mathrm{NO}$, and $\mathrm{NO}_{2}$. Although the derived rate constant was not independent of $\left[\mathrm{H}_{2} \mathrm{O}\right]$, the values were within a factor of 2 of the mean value of $2.0 \times 10^{-3} \mathrm{~m}^{4} \mathrm{kN}^{-2} \mathrm{~s}^{-1}$, equal to $3.4 \times 10^{-38} \mathrm{~cm}^{6}$ molecule ${ }^{-2} \mathrm{~s}^{-1}$. This can be taken as an upper limiting value to the rate constant for the homogeneous gas phase reaction whose stoichiometry is given by eqn. (1). An overall rate in terms of $\left[\mathrm{N}_{2} \mathrm{O}_{3}\right]$ is also given.

Ref. (c)

This study was performed in a $1 \mathrm{~mm}$ diameter pyrex tube and no precautions were taken to avoid surface reaction. In view of the results in (b) these measurements are rejected as gas phase rate data. They might be useful in defining the rate in a heterogeneous converter. Note that the reported rate does not reflect the dependence on $[\mathrm{NO}]$ which was fixed at $1 \mathrm{~atm}$. This is unity (b). If this is introduced:

where

$$
d\left[\mathrm{HNO}_{2}\right] / d t=k^{\prime}[\mathrm{NO}][\mathrm{A}]\left[\mathrm{H}_{2} \mathrm{O}\right]^{2},
$$

$$
k^{\prime}=5 \times 10^{-54} \mathrm{~cm}^{9} \text { molecule }{ }^{-3} \mathrm{~s}^{-1},
$$

and

$$
[\mathrm{A}]=\left[\mathrm{NO}_{2}\right]+\left[\mathrm{N}_{2} \mathrm{O}_{3}\right]
$$

Note that the rate quoted from (c) in the Data section has occasionally been cited incorrectly as applicable in the rate expression

$$
d P_{\mathrm{HNO}_{2}} / d t=k P_{\mathrm{NO}} P_{\mathrm{NO}_{2}} P_{\mathrm{H}_{2} \mathrm{O}},
$$

that is without the second order dependence on water.

\section{References}

(a) D. D. Wagman, et al, NBS Technical Note 270-3 (Jan. 1968).

(b) R. F. Graham and B. J. Tyler, J. Chem. Soc. Far. Trans I 68, 683 (1972).

(c) L. G. Wayne and D. M. Yost, J. Chem. Phys. 19, 41 (1951); ibid 18, 767 (1950).

D. H. Stedman

R. F. Hampson

July, 1972

\subsection{The Reaction Befween $\mathrm{H}_{2} \mathrm{O}$ and $\mathrm{N}_{2} \mathrm{O}_{5}$}

$$
\mathrm{H}_{2} \mathrm{O}+\mathrm{N}_{2} \mathrm{O}_{5} \rightarrow 2 \mathrm{HNO}_{3}
$$

$$
\Delta \mathrm{H}_{298}^{\circ}=-40 \mathrm{~kJ} / \mathrm{mol}\left(\begin{array}{c}
\text { Auxiliary Data } \\
-9.5 \mathrm{kcal} / \mathrm{mol}) \\
\text { Data }
\end{array}\right.
$$

There are no published quantitative data on the rate of this reaction.

\section{Preferred Value}

(Changed from that in NBS Report 10692 (Jan. 1972).)

$$
\begin{gathered}
k_{1}(300 \mathrm{~K})<10^{-20} \mathrm{~cm}^{3} \text { molecule }{ }^{-1} \mathrm{~s}^{-1} . \\
\text { Remarks }
\end{gathered}
$$

There is no evidence that this reaction occurs. It has been postulated as a possible regenerative step for $\mathrm{HNO}_{3}$ in the photolysis of mixtures of $\mathrm{NO}_{2}$ and $\mathrm{HNO}_{3}$ at $366 \mathrm{~nm}$ (b), although it was not considered to be important in a similar study at $265 \mathrm{~nm}$ (c). Other homogeneous and heterogeneous reactions may serve the same purpose, so that the value in (b) must be consid. ered an upper limit. It is not clear how this value was obtained.

H. Johnston (d) in a discussion of his earlier work on the effects of foreign gases on the decomposition of
$\mathrm{N}_{2} \mathrm{O}_{5}$ (e) suggests that $k_{1}(323 \mathrm{~K})$ is less than $2 \times 10^{-19}$ $\mathrm{cm}^{3}$ molecule ${ }^{-1} \mathrm{~s}^{-1}$ and that Jaffe and Ford were observing a heterogeneous reaction. Niki, et al. (f) on the basis of a photochemical smog model estimate $k_{1}=10^{-21} \mathrm{~cm}^{3}$ molecule $\mathrm{e}^{-1} \mathrm{~s}^{-1}$ at $300 \mathrm{~K}$, a value supported by preliminary results from a direct study of the reaction which indicate $k_{1}<10^{-20} \mathrm{~cm}^{3}$ molecule ${ }^{-1}$ $\mathrm{s}^{-1}(\mathrm{~g})$. The latter is tentatively accepted as a realistic upper limit for the rate constant. Assuming a normal pre-exponential factor this reaction would have a rate constant at least 100 times slower at stratospheric temperatures $(220 \mathrm{~K})$ than at $300 \mathrm{~K}$.

\section{References}

(a) D. D. Wagman, et al., NBS Technical Note 270-3 (Jan. 1968).

(b) S. Jaffe and H. W. Ford, J. Phys. Chem. 71, 1832 (1967).

(c) T. Berces and S. Forgeteg, Trans. Faraday Soc. 66, 640 (1970).

(d) H. S. Johnston, Formation and Stability of Nitric Acid in the Stratosphere, typescript, University of California, Berkeley, California (1971).

(e) H. S. Johnston, J. Am. Chem. Soc. 75, 1567 (1953).

(f) H. Niki, E. E. Daby, and B. Weinstock, Advan. Chem. Series, to appear.

(g) H. Niki, private communication to D. Garvin, 1972.

J. T. Herron, R. E. Huie

March, 1972

Revised: January, 1973 
4.18. The Reaction Befween $\mathrm{H}_{2} \mathrm{O}$ and $O\left({ }^{1} D\right)$

\begin{tabular}{l|lll}
\hline & \multicolumn{3}{|c}{$\Delta H_{298}^{\circ}(\mathrm{a}, \mathrm{b})$} \\
\hline $\mathrm{H}_{2} \mathrm{O}+\mathrm{O}\left({ }^{\circ} \mathrm{D}\right) \rightarrow \mathrm{HO}+\mathrm{HO}$, & $-119.2 \mathrm{~kJ} \mathrm{~mol}^{-1}$ & $\left(-28.50 \mathrm{kcal} \mathrm{mol}^{-1}\right)$ & $k_{1 \mathrm{a}}$ \\
$\rightarrow \mathrm{O}\left({ }^{3} \mathrm{P}\right)+\mathrm{H}_{2} \mathrm{O}$ & -189.8 & $(-45.36)$ & $k_{\mathrm{sb}}$ \\
$\rightarrow \mathrm{H}_{2} \mathrm{O}_{2}$ & -333.4 & $(-79.69)$ & $k_{1 \mathrm{c}}$ \\
$\rightarrow \mathrm{H}_{2}+\mathrm{O}_{2}$ & -197.1 & $(-47.11)$ & $k_{1 \mathrm{~d}}$ \\
\hline
\end{tabular}

Auxiliary Data

Reaction (1) has been studied only in relative rate experiments.

Comparison reactions are:

\begin{tabular}{l|lll}
\hline \hline & \multicolumn{3}{|c}{$\Delta H_{298}^{\circ}(\mathrm{a}, \mathrm{b})$} \\
\hline $\mathrm{N}_{2}+\mathrm{O}\left({ }^{1} D\right) \rightarrow \mathrm{N}_{2}+\mathrm{O}\left({ }^{3} P\right)$ & $-189.8 \mathrm{~kJ} \mathrm{~mol}^{-1}$ & $(-45.36) \mathrm{kcal} \mathrm{mol}^{-1}$ & $k_{2}$ \\
$\mathrm{O}\left({ }^{1} D\right)+\mathrm{O}_{3} \rightarrow \mathrm{O}_{2}+\mathrm{O}_{2}$ & -581.6 & $(-139.01)$ & $k_{3}$ \\
$\mathrm{O}\left({ }^{1} D\right)+\mathrm{O}_{2} \rightarrow \mathrm{O}\left({ }^{3} P\right)+\mathrm{O}_{2}$ & -189.8 & $(-45.36)$ & $k_{4}$ \\
$\mathrm{C}_{5} \mathrm{H}_{12}+\mathrm{O}\left({ }^{1} D\right) \rightarrow \mathrm{C}_{5} \mathrm{H}_{11} \mathrm{OH}$ & -589.1 & $(-140.8)$ & $k_{5}$ \\
$\mathrm{~N}_{2} \mathrm{O}+\mathrm{O}\left({ }^{1} D\right) \rightarrow \mathrm{N}_{2}+\mathrm{O}_{2}$ & -521.0 & $(-124.52)$ & $k_{6 \mathrm{a}}$ \\
$\mathrm{N}_{2} \mathrm{O}+\mathrm{O}\left({ }^{(} D\right) \rightarrow \mathrm{NO}+\mathrm{NO}$ & -340.5 & $(-81.38)$ & $k_{6 \mathrm{~b}}$ \\
$\mathrm{CO}+\mathrm{O}\left({ }^{1} D\right) \rightarrow \mathrm{CO}+\mathrm{O}\left({ }^{3} P\right)$ & -189.8 & $(-45.36)$ & $k_{7}$ \\
\hline
\end{tabular}

\section{Preferred Values}

(Changed from that in NBS Report 10828 (April 1972).)

\section{Ratios (o)}

$$
\begin{aligned}
& k_{1}\left(\mathrm{H}_{2} \mathrm{O}\right) / k_{3}\left(\mathrm{O}_{3}\right)=0.70 \\
& k_{1}\left(\mathrm{H}_{2} \mathrm{O}\right) / k_{4}\left(\mathrm{O}_{2}\right)=4.7
\end{aligned}
$$

$k_{1}\left(\mathrm{H}_{2} \mathrm{O}\right) / k_{2}\left(\mathrm{~N}_{2}\right)=6.4$ at $300 \mathrm{~K}$. Reproducibility 20-30 percent.

\section{Absolute Value}

$k_{1}=3.5 \times 10^{-10} \mathrm{~cm}^{3}$ molecule $\mathrm{e}^{-1} \mathrm{~s}^{-1}$.

Uncertainty: $\log k \pm 0.1$

\section{Remarks}

The preferred values are those developed by Cvetanovic (o), see below, from an analysis of all rate ratio data for reactions of $\mathrm{O}\left({ }^{1} D\right)$. The ratios are more reliable than the absolute value since the uncertainty in the latter must reflect the errors in the available absolute measurements of $\mathrm{O}\left({ }^{1} D\right)$ rate constants.

The rate ratios probably are sufficiently accurate for atmospheric modelling. All of the reactions of $\mathrm{O}\left({ }^{1} D\right)$ with major and trace components of the atmosphere are very fast, only the competition among them is important. For this reason the rate ratios are more important than the absolute values.

Comments on Measurements

$\xi$

Ref. $(c)$

Large extent of decomposition of $\mathrm{O}_{3}$ during and immediately after the (relatively long) flash make it difficult to assess the primary quantum yield and contribution from other reactions. (The value 0.45 is not given in the paper. It has been derived from the data and mechanism.

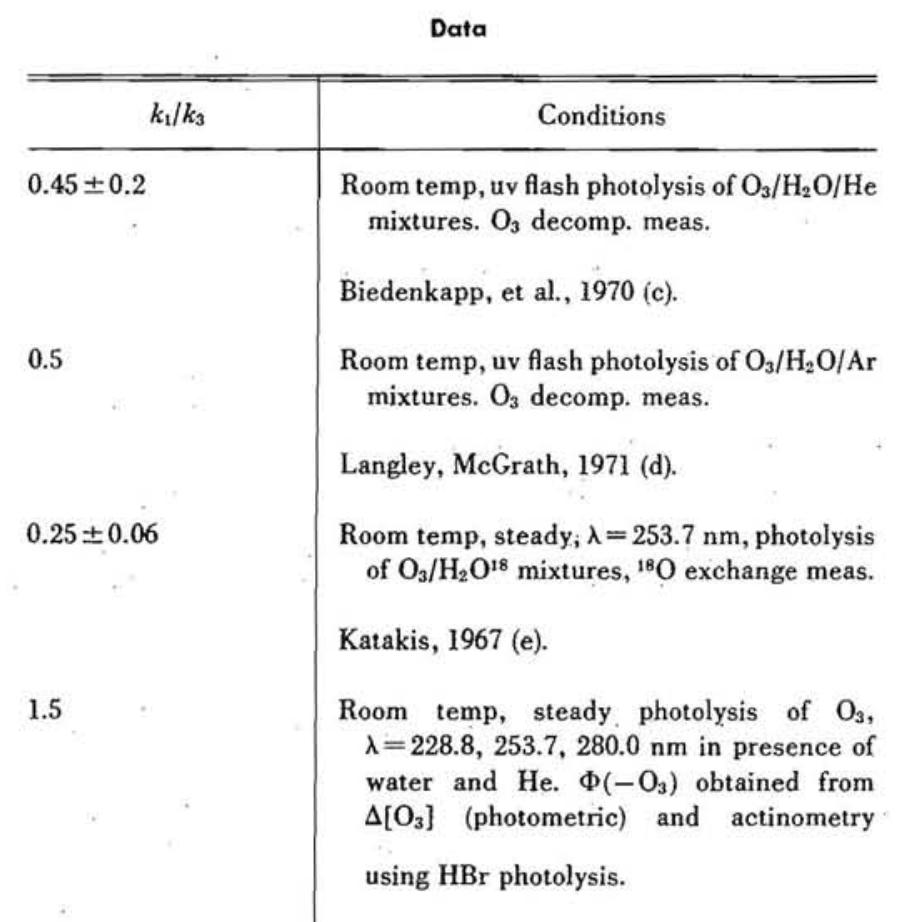

Lissi, Heicklen, 1972 (k).
$k_{1} /\left(k_{6 \mathrm{a}}+k_{6 \mathrm{~b}}\right)=$ $1.50 \pm 0.06$
Uv flash photolysis of $\mathrm{O}_{3}$ in $\mathrm{O}_{3} / \mathrm{N}_{2} \mathrm{O} / \mathrm{H}_{2} \mathrm{O}$ mixt. vs. the same $\mathrm{O}_{3} / \mathrm{N}_{2} \mathrm{O}$ mixt. at $23 \pm 1$ ${ }^{\circ} \mathrm{C}$. $\left[\mathrm{O}_{3}\right]=0.4-2.3$ torr, $\left[\mathrm{N}_{2} \mathrm{O}\right]=25-400$ torr, $\left[\mathrm{H}_{2} \mathrm{O}\right] /\left[\mathrm{N}_{2} \mathrm{O}\right]<1 . \mathrm{N}_{2}$ production meas.

$k_{1} / k_{s}=0.38 \pm 0.03$

$k_{1 \mathrm{~b}} \sim 0$

$k_{1} /\left(k_{6 \mathrm{a}}+k_{6 \mathrm{~b}}\right)=2.1$

$k_{1 \mathrm{a}} / k_{1}>0.9$

$k_{\mathrm{s}} / k_{4}=5.0$

$k_{1} / k_{2}=3.5$

$k_{1} / k_{7}=$

$3.0(300 \mathrm{~K})$

$1.67(423 \mathrm{~K})$

$0.385 \exp (+600 / T)$
Scott, Cvetanovic, 1971 (f):

Steady photolysis of $\mathrm{N}_{2} \mathrm{O}, \lambda=213.9 \mathrm{~nm}$. in $\mathrm{N}_{2} \mathrm{O} / \mathrm{C}_{5} \mathrm{H}_{12} / \mathrm{SF}_{6} / \mathrm{H}_{2} \mathrm{O}$ mixtures at $25{ }^{\circ} \mathrm{C}$. $\left[\mathrm{N}_{2} \mathrm{O}\right]=3$ torr, $\left[\mathrm{C}_{5} \mathrm{H}_{40}\right]=10$ torr, $\left[\mathrm{SF}_{6}\right]=$ 300 torr, $\left[\mathrm{H}_{2} \mathrm{O}\right]=5-21$ torr. $\Delta \mathrm{C}_{5} \mathrm{H}_{11} \mathrm{OH} /$ $\Delta \mathrm{N}_{2}$ meas.

Same expts, 1-butene added as a test for $\mathrm{O}\left({ }^{3} \mathrm{P}\right) \cdot \mathrm{H}_{2} \mathrm{O}$ had no effect.

Paraskevopoulos, Cvetanovic, 1971 (g).

Steady photolysis of $\mathrm{N}_{2} \mathrm{O}$ in presence of $\mathrm{H}_{2} \mathrm{O}$ and $\mathrm{CO}$. Relative yields of $\mathrm{CO}_{2}$ and $\mathrm{N}_{2}$ measured.

Simonaitis, Heicklen, 1972 (1).

Quenching of radiation from $\mathrm{O}_{2}\left({ }^{1} \Sigma\right)$ in 254 nm photolysis of $\mathrm{O}_{3}$.

Gauthier, Snelling, 1972 (m).

Flash photolysis of $\mathrm{O}_{3} / \mathrm{H}_{2} \mathrm{O} / \mathrm{N}_{2}$ mixtures. $\left[\mathrm{O}_{3}\right]$ vs. $t$ measured.

Fortin, Snelling, Tardif, 1972 (n).

Steady photolysis of $\mathrm{NO}_{2}, \lambda=228.8 \mathrm{~nm}$ in $\mathrm{NO}_{2} / \mathrm{H}_{2} \mathrm{O} / \mathrm{CO} / \mathrm{He}$ mixtures. Actinometry using $\mathrm{NO}_{2} / \mathrm{N}_{2} \mathrm{O}$ mixtures. $\Phi\left(\mathrm{CO}_{2}\right)$ meas.

Simonaitis, Heicklen 1972 (j). 
Ref. $(d)$

Pending a more detailed report of the measurements, the $\left[\mathrm{H}_{2} \mathrm{O}\right]$ at which a limiting quantum yield is reached cannot be assessed. This limit is used in setting the rate ratio.

\section{Ref. $(e)$}

$\mathrm{O}$-atom exchange was measured in steady photolysis of $\mathrm{O}_{3} / \mathrm{H}_{2} \mathrm{O}$ mixtures. The resultant rate ratio is strongly dependent upon the mechanism and on the efficiency of a chain reaction in recycling the oxygen.

\section{Ref. $(f)$}

Simultaneous photolysis of two mixtures, one containing a quenching gas $\left(\mathrm{H}_{2} \mathrm{O}, \mathrm{Xe}, \mathrm{He}, \mathrm{SF}_{6}, \mathrm{O}_{2}, \mathrm{CO}_{2}\right.$, neopentane). Results do not depend upon $k_{6 \mathrm{a}} / k_{6 \mathrm{~b}}$.

Ref. (g)

Water decreases the production of $\mathrm{C}_{5} \mathrm{H}_{11} \mathrm{OH}$. Effect assigned to competition between reactions (1a) and (5) since reaction (lb) was shown to be unimportant. Results consistent with $k_{1} / k_{5}=0.35 \pm 0.03$ derived from ref (f). Results do not depend upon $k_{6 \mathrm{a}} / k_{6 \mathrm{~b}}$.

Ref. $(j)$

In this study $k_{1} / k_{7}$ and the ratio of rates for

$$
\begin{gathered}
\mathrm{HO}+\mathrm{NO}_{2}(+\mathrm{M}) \rightarrow \mathrm{HNO}_{3} \\
\mathrm{HO}+\mathrm{CO} \rightarrow \mathrm{CO}_{2}+\mathrm{H}
\end{gathered}
$$

were determined simultaneously. Experiments under extreme conditions permitted both ratios to be established. The temperature coefficient is believed to apply to $k_{7}$, not $k_{1}$.

Ref. $(k)$

The experiments show $\Phi\left(-\mathrm{O}_{3}\right)$ to rise from a minimum value $\sim 5.5$ when $P\left(\mathrm{H}_{2} \mathrm{O}\right)=0$ and pass through a maximum at $P\left(\mathrm{H}_{2} \mathrm{O}\right) \sim 4$ torr. See fig. 7 in ref. (k). At low $\left[\mathrm{H}_{2} \mathrm{O}\right], \Phi$ is proportional to $\left[\mathrm{H}_{2} \mathrm{O}\right]^{0.5}$. The authors estimate $k_{1} / k_{3} \sim 1.5$ from $\Phi$ at $\left(\Phi_{\max }-\Phi_{0}\right) / 2$. At this point $k_{3}\left[\mathrm{O}_{3}\right]=3 k_{1}\left[\mathrm{H}_{2} \mathrm{O}\right]$. The mechanism is complex, the estimate approximate.

Ref. (l)

These experiments determine the relative rates of reaction of $\mathrm{H}_{2} \mathrm{O}$ and $\mathrm{N}_{2} \mathrm{O}$ with $\mathrm{O}\left({ }^{1} D\right)$ by following $\mathrm{CO}_{2}$ production from $\mathrm{CO}+\mathrm{HO} \rightarrow \mathrm{CO}_{2}+\mathrm{H}$ as a function of
$\left[\mathrm{N}_{2} \mathrm{O}\right] /\left[\mathrm{H}_{2} \mathrm{O}\right]$. The ratio applies to the sum of the following four reactions

$$
\begin{array}{rlr}
\mathrm{O}\left({ }^{1} D\right)+\mathrm{H}_{2} \mathrm{O} & \rightarrow 2 \mathrm{HO} & >90 \% \\
& \rightarrow \mathrm{H}_{2} \mathrm{O}+\mathrm{O}\left({ }^{3} P\right) & <4 \% \\
& \rightarrow \mathrm{H}_{2} \mathrm{O}_{2} & <5 \% \\
& \rightarrow \mathrm{H}_{2}+\mathrm{O}_{2} & <0.4 \%
\end{array}
$$

the relative importance of which is shown at the right.

Ref. (o)

An evaluation of all data available in Nov. 1972 for reactions of $\mathrm{O}\left({ }^{1} D\right)$ with $\mathrm{CH}_{4}, \mathrm{C}_{2} \mathrm{H}_{6}, \mathrm{C}_{3} \mathrm{H}_{8}, \mathrm{C}_{5} \mathrm{H}_{12}, \mathrm{CO}$, $\mathrm{CO}_{2}, \mathrm{H}_{2}, \mathrm{H}_{2} \mathrm{O}, \mathrm{N}_{2}, \mathrm{NO}, \mathrm{NO}_{2}, \mathrm{~N}_{2} \mathrm{O}, \mathrm{O}_{2}, \mathrm{O}_{3}$ and the rare gases. These rate ratio data form an interconnected net, solution of which yields a self consistent set of rate ratios. The data network is displayed in the data sheet on $\mathrm{O}(\cdot D)+\mathrm{N}_{2} \mathrm{O}$. The relative rates pertinent to the data listed in this review are $1.0\left(\mathrm{CO}_{2}\right), 0.42\left(\mathrm{O}_{2}\right)$, $2.8\left(\mathrm{O}_{3}\right), 0.30\left(\mathrm{~N}_{2}\right), 1.22\left(\mathrm{~N}_{2} \mathrm{O}\right), 0.42(\mathrm{CO}), 1.95\left(\mathrm{H}_{2} \mathrm{O}\right)$.

\section{References}

(a) D. D. Wagman, et al., NBS Tech. Note 270-3 (Jan. 1968).

(b) C. E. Moorc, NBS Circular 467. vol. 1 (1949).

(c) D. Biedenkapp, L. G. Hartshorn, and E. J. Bair, Chem. Phys Lettrs. 5, 379 (1970).

(d) K. F. Langley and W. D. McGrath, Planet. Space Sci. 19, 413 (1971).

(e) D. Katakis, J. Chem. Phys. 47,541 (1967)

(f) P. M. Scott and R. J. Cvetanovic, J. Chem. Phys. 54, 1440 (1971).

(g) G. Paraskevopoulos and R. J. Cvetanovic, Chem. Phys. Lettr. 9, 603 (1971).

(h) J. F. Noxon, J. Chem. Phys. 52, 1852 (1970)

(i) R. Gilpin, H. I. Schiff, and K. H. Welge, J. Chem. Phys. 55, 1087 (1971).

(j) R. Simonaitis and J. Heicklen Int. J. Chem. Kinetics 4, 529 (1972).

(k) E. Lissi and J. Heicklen, J. Photochem 1, 39 (1972/73).

(l) R. Simonaitis and J. Heicklen, The reaction of $\mathrm{O}\left({ }^{1} D\right)$ with $\mathrm{H}_{2} \mathrm{O}$ and the reaction of $\mathrm{OH}$ with $\mathrm{C}_{3} \mathrm{H}_{6}$, (Pennsylvania State University, Ionospheric Research Laboratory Scientific Report 397, Sept 5, 1972).

(m) M. Gauthier and D. R. Snelling, letters to R. F. H. and D. G. (1972).

(n) C. J. Fortin, D. R. Snelling, and A. Tardif, Can. J. Chem. 50, 2747 (1972).

(o) R. Cvetanovic The Reactions of $\mathrm{O}\left({ }^{1} D_{2}\right)$, in The Natural Stratosphere, E. Reiter, editor (Climatic Impact Assessment Program, Monograph 1), preliminary draft, November 1972.

(p) R. F. Heidner, D. Husain, and J. R. Wiesenfeld, Chem. Phys. Lett. 16, 488 (1972).

David Garvin

March, 1972

Revised: January, 1973 


\subsection{Photolysis of $\mathrm{H}_{2} \mathrm{O}_{2}, \lambda<300 \mathrm{~nm}$}

Primary Photochemical Transitions

\begin{tabular}{|c|c|c|c|c|}
\hline \multirow{3}{*}{$\begin{array}{r}\text { Reaction } \\
\mathrm{H}_{2} \mathrm{O}_{2} \rightarrow 2 \mathrm{HO}\left(X^{2} \Pi\right)\end{array}$} & \multicolumn{2}{|c|}{$\Delta \mathrm{H}_{0}^{\circ}$} & \multirow{2}{*}{\multicolumn{2}{|c|}{$\begin{array}{c}\lambda \text { threshold } \\
(\mathrm{nm})\end{array}$}} \\
\hline & \multirow{2}{*}{$\frac{\mathrm{kJ} / \mathrm{mol}}{207}$} & \multirow{2}{*}{$\frac{\mathrm{kcal} / \mathrm{mol}}{(49.6)}$} & & \\
\hline & & & 577 & (1) \\
\hline$\rightarrow \mathrm{HO}\left(X^{2} \Pi\right)+\mathrm{HO}\left(A^{2} \Sigma\right)$ & 598 & $(142.9)$ & 200 & (2) \\
\hline$\rightarrow \mathrm{H}+\mathrm{HO}_{2}$ & 371 & $(88.7)$ & 322 & (3) \\
\hline$\rightarrow 2 \mathrm{H}+\mathrm{O}_{2}\left(X^{3} \Sigma_{\bar{g}}\right)$ & 562 & $(134.3)$ & 213 & (4) \\
\hline$\rightarrow \mathrm{H}_{2}+\mathrm{O}_{2}\left(a^{1} \Delta_{g}\right)$ & 224 & $(53.6)$ & 533 & (5) \\
\hline$\rightarrow \mathrm{H}_{2}+\mathrm{O}_{2}\left(b^{1} \Sigma_{\ddagger}\right)$ & 287. & $(68.6)$ & 417 & (6) \\
\hline$\rightarrow \mathrm{H}_{2}+2 \mathrm{O}\left({ }^{3} P\right)$ & 624 & $(149.0)$ & 192 & (7) \\
\hline$\rightarrow \mathrm{H}_{2} \mathrm{O}+\mathrm{O}\left({ }^{1} D\right)$ & 328 & $(78.3)$ & 365 & (8) \\
\hline
\end{tabular}

$\Delta \mathrm{H}_{0}^{\circ}$ calculated using $\Delta \mathrm{H}^{\circ}$ values in (a) and excitation energies of $\mathrm{OH}\left({ }^{2} \Sigma\right), \mathrm{O}_{2}\left({ }^{1} \Delta\right)$, and $\mathrm{O}_{2}\left({ }^{1} \Sigma\right)$ from (b).

\section{Data}

Absorption spectrum and absorption coefficient

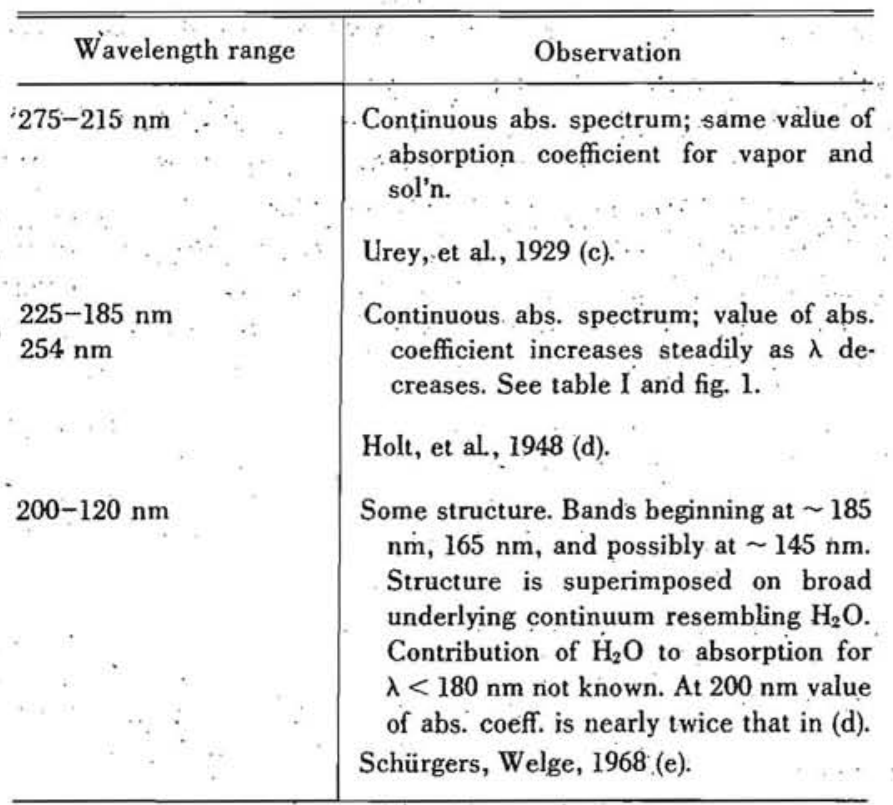

Quantum yields

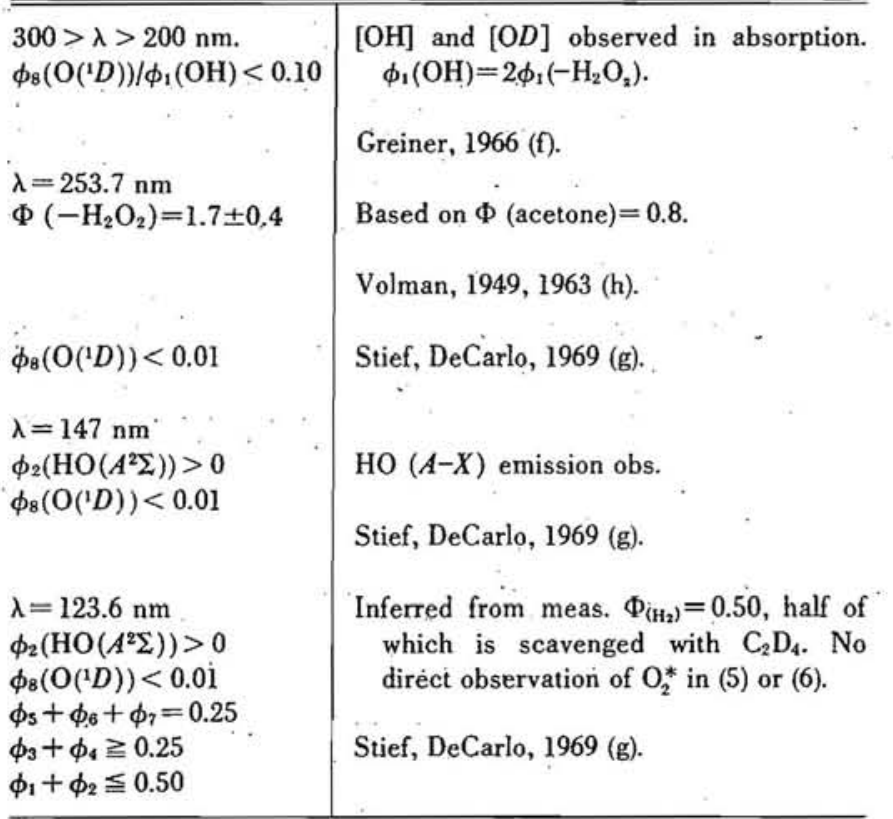

\section{Preferred Values}

Absorption coefficients, $200<\lambda<300 \mathrm{~nm}$ : Data of reference (d) see table I and fig. I.

Quantum yields, $200<\lambda<300 \mathrm{~nm}: \phi_{1}\left(-\mathrm{H}_{2} \mathrm{O}_{2}\right) \sim 1$. $\lambda<200 \mathrm{~nm}$ : No recommendation.

\section{Remarks \\ Absorption Coefficients}

The corrected data from ref. (d) are selected here. Relative absorption coefficients (i) match the wavelength dependence. There is good agreement between (d) and (c) at $220 \mathrm{~nm}$. Measurements in the vacuum uv (e) give an absorption coefficient 2 times the value in (d) at $200 \mathrm{~nm}$. The cause of the discrepancy is unknown.

\section{Quantum yields}

$\lambda>200 \mathrm{~nm}$

The only data are from one study (h) in which the overall quantum yield is $\Phi\left(-\mathrm{H}_{2} \mathrm{O}_{2}\right)=1.7 \pm 0.4$ based on the mechanism:

$$
\begin{gathered}
\mathrm{H}_{2} \mathrm{O}_{2}+h \nu(\lambda=253.7 \mathrm{~nm}) \rightarrow 2 \mathrm{HO} \\
\mathrm{HO}+\mathrm{H}_{2} \mathrm{O}_{2} \rightarrow \mathrm{H}_{2} \mathrm{O}+\mathrm{HO}_{2} \\
2 \mathrm{HO}_{2} \rightarrow \mathrm{H}_{2} \mathrm{O}_{2}+\mathrm{O}_{2}
\end{gathered}
$$

This leads to $\phi_{1}\left(-\mathrm{H}_{2} \mathrm{O}_{2}\right) \sim 1$, which is reasonable. Greiner has criticized some of the tests in support of the above mechanism and suggests that $\mathrm{O}$ atoms could be formed in the photolytic step and still give the observed quantum yield. There are no data on this point.

$\lambda<200 \mathrm{~nm}$

These data, ref. (g), are important primarily because they indicate what photolytic processes occur. The numerical values are based on $\mathrm{H}_{2}$ production in the absence and presence of $\mathrm{C}_{2} \mathrm{D}_{4}$ (which scavenges $\mathrm{H}$ atoms), and are put on an absolute basis by using $\mathrm{CO}_{2}$ as an actinometer. Although the trends reported clearly are present, the absolute values for the $\phi$ 's may have a large uncertainty.

\section{References}

(a) D. D. Wagman, et al., NBS Technical Note 270-3 (Jan. 1968).

(b) G. Herzberg, Spectra of Diatomic Molcules, D. Van Nostrand Co. Inc., New York (1950).

(c) H. C. Urey, L. H. Dawsey, and F. O. Rice, J. Am. Chem. Soc. 51, 1371 (1929).

(d) R. B. Holt, C. K. McLane, and O. Oldenberg, J. Chem. Phys. 16, 225,638 [erratum] (1948).

(e) M. Schürgers and K. H. Welge, Z. Naturforsch. 23a, 1508 (1968).

(f) N. R. Greiner, J. Chem. Phys. 45, 99 (1966).

(g) L. J. Stief, and V. J. DeCarlo, J. Chem. Phys. 50, 1234 (1969). 
(h) D. H. Volman, J. Chem. Phys. 17, 947 (1949); Adv. Photochem. 1, 43 (1963).

(i) T. T. Paukert and H. S. Johnston, J. Chem. Phys. 56, 2824 (1972).

A. H. Laufer, M. J. Kurylo, W. Braun

March, 1972

TABLE I. Values of absorption coefficient of $\mathrm{H}_{2} \mathrm{O}_{2}, 185-225 \mathrm{~nm}$. (read from corrected figure 1 of ref. (d), J. Chem. Phys. 16, 638 (1948))

\begin{tabular}{c|c}
\hline \hline$\lambda(\mathrm{nm})$ & $10^{20} \sigma, \mathrm{cm}^{2}$ \\
\hline 190 & 80 \\
195 & 60 \\
200 & 54 \\
205 & 46 \\
210 & 40 \\
215 & 34 \\
220 & 28 \\
225 & 24 \\
254 & 7.4 \\
\hline
\end{tabular}

The absorption coefficient is defined by the eqn:

$$
\sigma=(1 / c l) \log _{e}\left(I_{0} / I\right),
$$

where $c$ is conc. in molecules $/ \mathrm{cm}^{3}, l$ is the path length in $\mathrm{cm}, I_{0}$ and $I$ are the incident and transmitted light intensities. The value for $254 \mathrm{~nm}$ is from the original paper by Holt, et al., J. Chem. Phys. 16, 225 (1948).

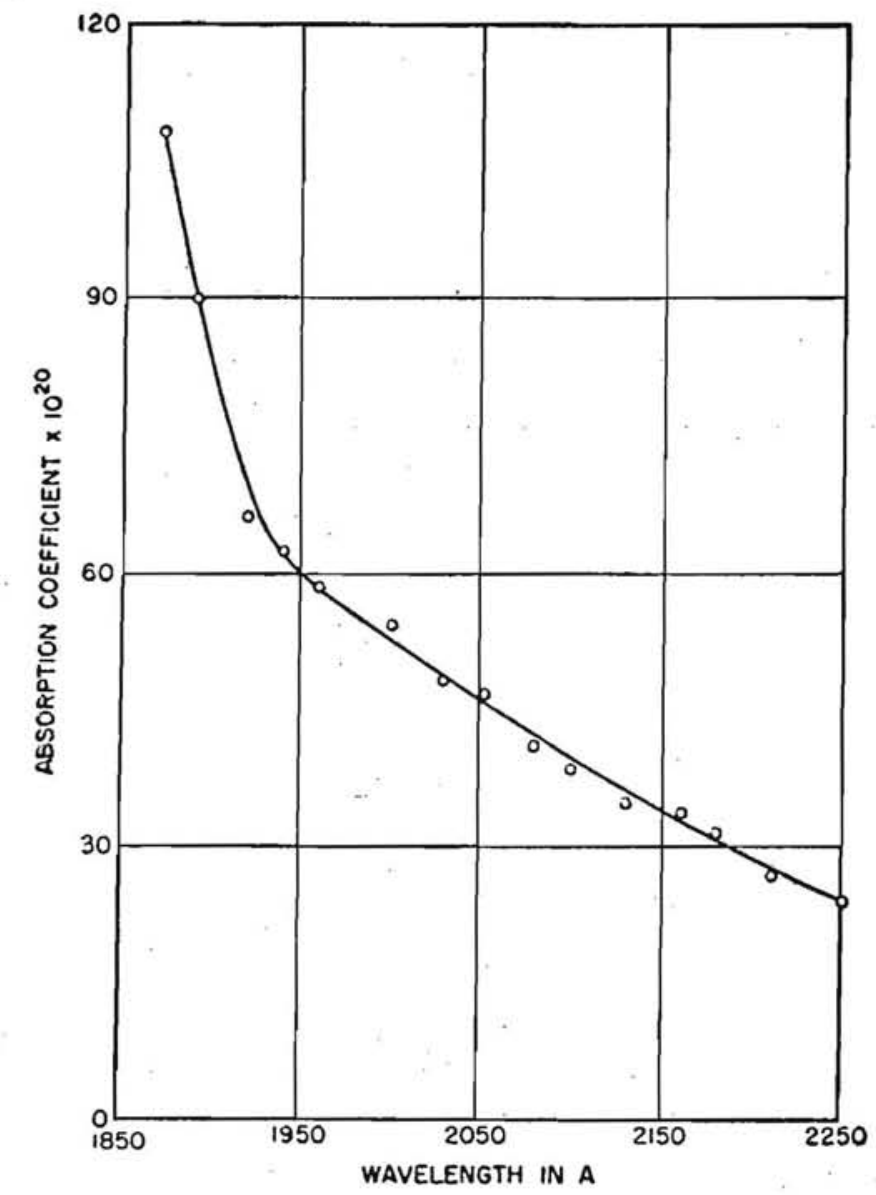

Figure 1. Absorption coefficient $\sigma$ for $\mathrm{H}_{2} \mathrm{O}_{2}$ vapor. Same data as in table I. Units of $\sigma$ are $\mathrm{cm}^{2}$. For definition of $\sigma$ see footnote to table I. Holt, et al. (corrected fig. 1 of ref. (d), J. Chem. Phys. 16, $638(1948))$.

4.20. The Reaction Between $\mathrm{H}_{2} \mathrm{O}_{2}$ and NO

$$
\begin{aligned}
\mathrm{H}_{2} \mathrm{O}_{2}+\mathrm{NO} & \rightarrow \mathrm{H}_{2} \mathrm{O}+\mathrm{NO}_{2} \text { (overall reaction) } \\
& \rightarrow \mathrm{HNO}+\mathrm{HO}_{2} \\
& \rightarrow \mathrm{HNO}_{2}+\mathrm{OH} \\
& \rightarrow \mathrm{HNO}_{3}+\mathrm{H}
\end{aligned}
$$

\section{Auxiliary Data}

$\Delta H_{298}^{\circ}(0)=-163 \mathrm{~kJ} / \mathrm{mol}(-38.9 \mathrm{kcal} / \mathrm{mol})$

$\Delta H_{298}^{\circ}(\mathrm{la})=166 \mathrm{~kJ} / \mathrm{mol}(40 \mathrm{kcal} / \mathrm{mol})$

$\Delta H_{298}^{\circ}(\mathrm{lb})=5.5 \mathrm{~kJ} / \mathrm{mol}(1.3 \mathrm{kcal} . \mathrm{mol})$

$\Delta H_{298}^{\circ}(\mathrm{lc})=129 \mathrm{~kJ} / \mathrm{mol}(30.8 \mathrm{kcal} / \mathrm{mol})$

$$
\begin{gathered}
k_{0} \\
k_{1 \mathrm{a}} \\
k_{1 \mathrm{~b}} \\
k_{1 \mathrm{c}}
\end{gathered}
$$

\begin{tabular}{|c|c|}
\hline Quantity Measured & System \\
\hline $\begin{array}{l}k_{\mathrm{t}}<5 \times 10^{-20} \\
\quad \mathrm{~cm}^{3} \text { molecule }{ }^{-1} \mathrm{~s}^{-1} \\
\quad(T=298 \mathrm{~K})\end{array}$ & $\begin{array}{l}\mathrm{H}_{2} \mathrm{O}_{2}(0.5-1.5 \text { torr }) \text { and } \mathrm{NO}(1-12 \text { torr }) \\
\text { allowed to react in presence of } 1-2 \text { torr } \\
\text { Ar. [NO], }\left[\mathrm{H}_{2} \mathrm{O}_{2}\right],\left[\mathrm{NO}_{2}\right] \text { followed by mass } \\
\text { spectrometry [ }\left[\mathrm{NO}_{2}\right] \text { also measured by } \\
\text { optical absorption. } \\
\text { Gray, Lissi, Heicklen, } 1972(\mathrm{~g}) \text {. }\end{array}$ \\
\hline
\end{tabular}

\begin{tabular}{c|c|c}
\multicolumn{3}{c}{ Data } \\
\hline \hline$k\left(\mathrm{~s}^{-1}\right)$ & $T(K)$ & System \\
\hline 0.032 & 491 & $\mathrm{H}_{2} \mathrm{O}_{2}(2-12$ torr) and $\mathrm{NO}(3-40$ torr) allowed \\
.115 & 521 & to react in excess $\mathrm{N}_{2}, \mathrm{He}$, or $\mathrm{CO}_{2}$. Meas- \\
.42 & 550 & ured initial $d\left[\mathrm{NO}_{2}\right] / d t$ and initial $d P / d t$. \\
.76 & 569 & \\
1.57 & 588 & Asquith, $1969(\mathrm{c})$. \\
2.53 & 601 & \\
\hline
\end{tabular}

$d\left[\mathrm{NO}_{2}\right] / d t$ (initial) $=k\left[\mathrm{H}_{2} \mathrm{O}_{2}\right]^{2} /[\mathrm{M}]$. When data for $k$ are expressed in Arrhenius form: $A=7 \times 10^{8} \mathrm{~s}^{-1}$ and $E=23.4 \mathrm{kcal} / \mathrm{mol}(98 \mathrm{~kJ} / \mathrm{mol})$ $\left(k_{2} / k_{4}\right)_{\tau=550 \mathrm{~K}}=3.7 \times 10^{-5} \mathrm{~mol} / \mathrm{cm}^{3}$. Asquith, 1969 (c) (see Remarks section for definition of rate constants).
Preferred Value

(Changed from that in NBS Report 10828 (April 1972).)

$k_{1}(550 \mathrm{~K}) \sim 2 \times 10^{-20} \mathrm{~cm}^{3}$ molecule $\mathrm{e}^{-1} \mathrm{~s}^{-1}$.

$k_{1}(300 \mathrm{~K})<5 \times 10^{-20} \mathrm{~cm}^{3}$ molecule ${ }^{-1} \mathrm{~s}^{-1}$.

Remarks

The data in (c) are interpreted according to the following mechanism:

$$
\begin{aligned}
\mathrm{H}_{2} \mathrm{O}_{2}+\mathrm{NO} & \rightarrow \mathrm{HNO}+\mathrm{HO}_{2} \\
& \rightarrow \mathrm{HNO}_{2}+\mathrm{OH}
\end{aligned}
$$$$
\rightarrow \mathrm{HNO}_{3}+\mathrm{H} \rightarrow \mathrm{OH} \text { or } \mathrm{HO}_{2}
$$ 


$$
\begin{aligned}
& \mathrm{OH}+\mathrm{H}_{2} \mathrm{O}_{2} \rightarrow \mathrm{HO}_{2}+\mathrm{H}_{2} \mathrm{O} \\
& \mathrm{HO}_{2}+\mathrm{NO} \rightarrow \mathrm{OH}+\mathrm{NO}_{2} \\
& \mathrm{OH}+\mathrm{NO}+\mathrm{M} \rightarrow \mathrm{HNO}_{2}+\mathrm{M} \\
& \mathrm{OH}+\mathrm{NO}_{2}+\mathrm{M} \rightarrow \mathrm{HNO}_{3}+\mathrm{M}
\end{aligned}
$$

This mechanism leads to the expression:

$$
d\left[\mathrm{NO}_{2}\right] / d t(\text { initial })=\left(k_{1} k_{2} / k_{4}\right)\left(\left[\mathrm{H}_{2} \mathrm{O}_{2}\right]^{2} /[\mathrm{M}]\right) .
$$

From the measured values of $k=k_{1} k_{2} / k_{4}$ and of $k_{2} / k_{4}$ at $550 \mathrm{~K}$ the value of $k_{1}$ at $550 \mathrm{~K}$ is obtained. From the measured value of $23.4 \mathrm{kcal} / \mathrm{mol}$ for $E=E_{1}+E_{2}-E_{4}$ one can get an estimate of $E_{1}$. The value of $E_{2}$ has been estimated to be $1.8 \mathrm{kcal} / \mathrm{mol}$ (e). The author in (c) estimates $E_{4}$ to be $\rightarrow 7.5 \mathrm{kcal} / \mathrm{mol}$ assuming it to be equal to the value estimated for $E_{5}$ in (f). Although the magnitude of this number seems much too large it can be used to set a lower limit to the value of $E_{1}$ of $14 \mathrm{kcal} /$ mol. This leads to $k_{1}(300 \mathrm{~K})<10^{-24} \mathrm{~cm}^{3}$ molecule ${ }^{-1} \mathrm{~s}^{-1}$. Choosing the value of $E_{4}$ to be near zero permits one to calculate an upper limit of $22 \mathrm{kcal} / \mathrm{mol}$ for the value of $E_{1}$. It is likely that reaction (lb) is the initiating step, since it is the only elementary reaction with a $\Delta H$ less than the observed $E_{1}$.

The mechanism used in (c) was originally used in (d). There, in a detailed study at $572 \mathrm{~K}$, NO (up to 25 torr) and $\mathrm{H}_{2} \mathrm{O}_{2}$ (up to 14 torr) in excess $\mathrm{N}_{2}$ were allowed to react and the overall reaction shown to correspond to (1). The initial rate of formation of $\mathrm{NO}_{2}$ was found to be independent of $[\mathrm{NO}]$ and vessel diameter and to be of the form $\left.d \mathrm{NO}_{2}\right] / d t$ (initial) $=k\left[\mathrm{H}_{2} \mathrm{O}_{2}\right]^{x /}\left[\mathrm{N}_{2}\right]$ where $1.6<x<1.9$ depending on $\left[\mathrm{N}_{2}\right]$. The deviation of $x$ from the value 2 can be accounted for by participation of $\mathrm{H}_{2} \mathrm{O}_{2}$ as a third body in reaction (4).

The upper limiting value of $k_{1}(300 \mathrm{~K})$ in $(\mathrm{g})$ is derived on the basis of the observed decay of $\mathrm{H}_{2} \mathrm{O}_{2}$ in the presence of NO. It is far larger than the upper limit derived from the high temperature data (c). The possibility that the room temperature results are due to heterogeneous reactions cannot be ruled out.

\section{References}

(a) D. D. Wagman, et' al., NBS Technical Note 270-3 (Jan. 1968).

(b) D. R. Stull and H. Prophet, JANAF Thermochemical Tables, 2 d. Ed. Nat. Stand. Ref. Data Ser., Nat. Bur. Stand. (U.S.), 37 (June 1971).

(c) P. L. Asquith, The Gas-Phase Reactions of Hydrogen Peroxide with Oxides of Nitrogen. Thesis submitted to Dept. of Chemistry, University of Manchester (April 1969).

(d) B. J. Tyler, Nature 195, 279 (1962).

(e) D. D. Drysdale and A. C. Lloyd, Gas Phase Reactions of the Hydroxyl Radical, Oxidation "and Combustion Reviews 4, 157 (1970).

(f) M. G. Burnett, Ph.D. Thesis, University of Cambridge, 1961.

(g) D. Gray, E. Lissi, and J. Heicklen, J. Phys. Chem. 76, 1919 (1972).

W. Tsang, R. F. Hampson

March, 1972

Revised: January 1973

\subsection{The Reaction Between $\mathrm{NO}$ and $\mathrm{O}_{3}$}

$\mathrm{NO}+\mathrm{O}_{3} \rightarrow \mathrm{NO}_{2}+\mathrm{O}_{2}$

Auxiliary Data

$\Delta \mathrm{H}_{298}^{\circ}=-200 \mathrm{~kJ} / \mathrm{mol}(-47.7 \mathrm{kcal} / \mathrm{mol})$

Data

\begin{tabular}{c|c}
\hline \hline$k_{1}\left(\mathrm{~cm}^{3}\right.$ molecule & \\
\hline
\end{tabular}

$1.3 \times 10^{-12} \exp \left(-1.25 \times 10^{3} / T\right)$

$5 \times 10^{-14}$

$9.5 \times 10^{-13} \exp \left(-1.23 \times 10^{3} / T\right)$

$1.4 \times 10^{-14}$
Stopped-flow technique. Meas. at 198 and $230 \mathrm{~K}$ (total of 65 expts.)

Johnston, Crosby, 1954 (b):

$k_{1}$

(a)

Photolysis of $\mathrm{NO}_{2}$ in air, in a 50 liter stírred flow reactor, $302 \mathrm{~K}$.

Ford, et al., 1957 (c).

Flow system, infrared chemiluminescence, 216-322 K.

Clyne, et al., 1964 (d).

Flow system, infrared chemiluminescence, $293 \mathrm{~K}$.

Clough, Thrush, 1967 (e).
Data-Continued

\begin{tabular}{l|l}
\hline \hline \multicolumn{1}{c|}{$k_{1}\left(\mathrm{~cm}^{3}\right.$ molecule $\left.{ }^{-1} \mathrm{~s}^{-1}\right)$} & \multicolumn{1}{c}{ System } \\
\hline $2.1 \times 10^{-14}$ & $\begin{array}{l}\text { Flow system, mass spec. 298 K. } \\
\text { Phillips, Schiff, } 1962(\mathrm{f}) .\end{array}$ \\
$2.1 \times 10^{-14}$ & $\begin{array}{l}\text { Flow system, mass spec., 296 K. } \\
\text { Sharma, et al., } 1970(\mathrm{~g}) .\end{array}$ \\
$2.0 \times 10^{-12} \exp \left(-1.28 \times 10^{3} / T\right)$ & $\begin{array}{l}\text { Supersonic nozzle. Meas. } \Delta\left[\mathrm{O}_{3}\right] \\
\text { by absorption at } 254 \mathrm{~nm} .245- \\
345 \mathrm{~K} \text { (total of } 80 \text { expts.). }\end{array}$ \\
& Marte, et al., 1963 (h). \\
\hline
\end{tabular}

Preferred Value

$k(198-330 \mathrm{~K})=9 \times 10^{-13} \exp \left(-1.2 \times 10^{3} / T\right) \quad \mathrm{cm}^{3}$ molecule $\mathrm{e}^{-1} \mathrm{~s}^{-1}$, estimated uncertainty: \pm 30 percent over indicated temperature range.

$k(298 \mathrm{~K})=1.6 \times 10^{-14} \mathrm{~cm}^{3}$ molecule ${ }^{-1} \mathrm{~s}^{-1}$.

$k(220 \mathrm{~K})=3.8 \times 10^{-15} \mathrm{~cm}^{3}$ molecule ${ }^{-1} \mathrm{~s}^{-1}$. 


\section{Remarks}

The rate constant is given for the overall reaction. There are two reaction channels which have been identified, one leading to ground state $\mathrm{NO}_{2}$, the other to $\mathrm{NO}_{2}^{*}$ (probably $\left.\mathrm{NO}_{2}\left({ }^{2} B_{1}\right)\right)(\mathrm{d}, \mathrm{e}, \mathrm{i})$. The rate constant for the latter is reported to be $1.3 \pm 0.2 \times 10^{-12} \exp$ $(-2100 \pm 150 / T) \mathrm{cm}^{3}$ molecule ${ }^{-1} \mathrm{~s}^{-1}$ (e), which corresponds to about 2 percent of the total reaction at $220 \mathrm{~K}$.

The preferred values are derived from an Arrhenius plot of the data in (b) and (d). Although the total pressures used in (b) are not given, in the one case noted the total pressure was 565 torr. In (d) total pressure varied from 0.8 to 3 torr.

The other extensive set of data (h) is in good agreement with the preferred values. Because of the scatter in the data (about a factor of three at any given temperature) it was not used in arriving at the preferred value. With the exception of the data in (c), all the data ob- tained at or near room temperature $(e, f, g)$ are also in good agreement with the preferred value.

\section{References}

(a) D. D. Wagman, et al., NBS Technical Note 270-3 (Jan. 1968).

(b) H. S. Johnston and H. J. Crosby, J. Chem. Phys. 22, 689 (1954).

(c) H. W. Ford, G. J. Doyle, and N. Endow, J. Chem. Phys. 26, 1337 (1957).

(d) M. A. A. Clyne, B. A. Thrush, and R. P. Wayne, Trans. Faraday Soc. 60, 359 (1964).

(e) P. N. Clough and B. A. Thrush, Trans. Faraday Soc. 63, 915 (1967).

(f) L. F. Phillips and H. I. Schiff, J. Chem. Phys. 36, 1509 (1962).

(g) H. D. Sharma, R. E. Jervis, and K. Y. Wong, J. Phys. Chem. 74, 923 (1970).

(h) J. E. Marte, E. Tschuikow-Roux, and H. W. Ford, J. Chem. Phys. 39, 3277 (1963).

(i) A. E. Redpath and M. Menzinger, Can. J. Chem. 49, 3063 (1971).

J. T. Herron, R. E. Huie

February, 1972

Revised: January, 1973

\subsection{The Reaction Between $\mathrm{NO}_{2}$ and $\mathrm{O}_{3}$}

$$
\mathrm{NO}_{2}+\mathrm{O}_{3} \rightarrow \mathrm{NO}_{3}+\mathrm{O}_{2}
$$

Auxiliary Data

$\Delta H_{298}^{\circ}=-105 \pm 21 \mathrm{~kJ} / \mathrm{mol}(-25 \pm 5 \mathrm{kcal} / \mathrm{mol})$

Data

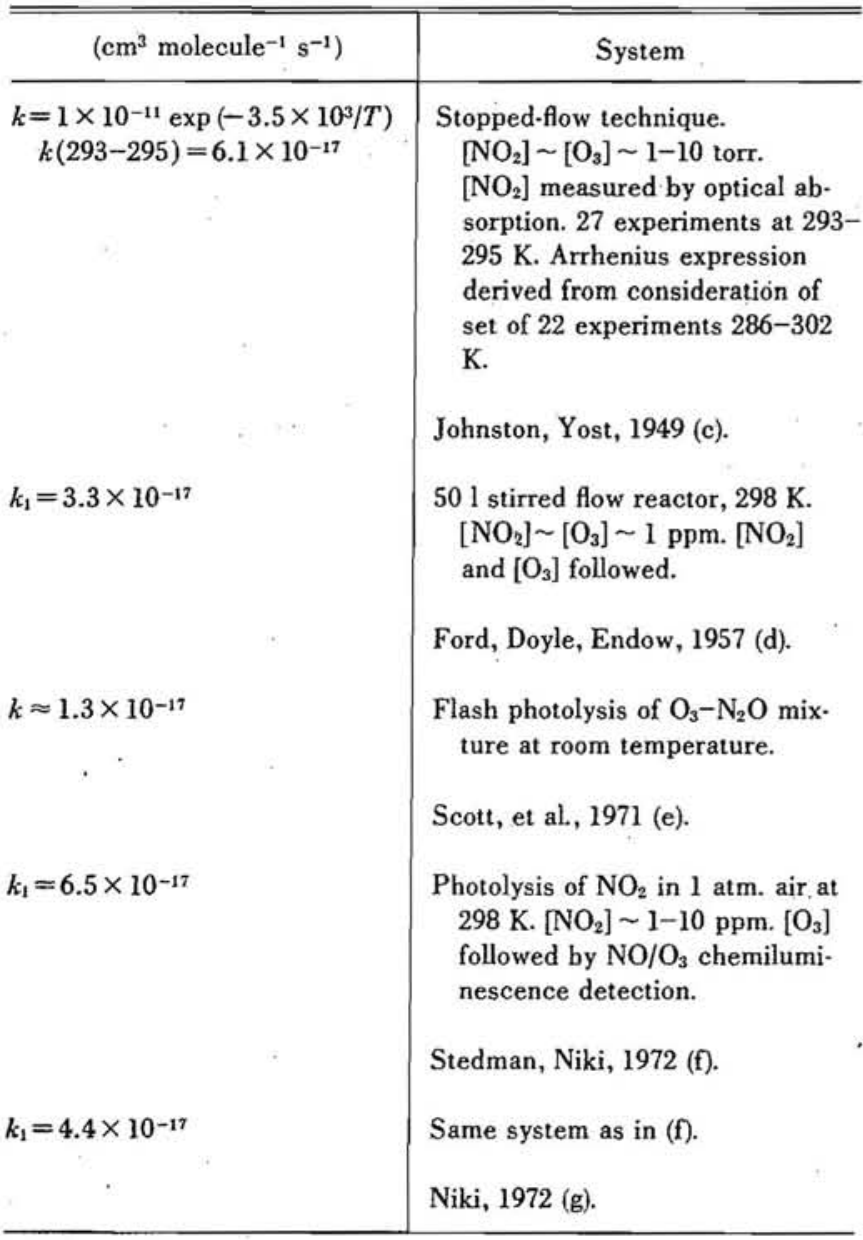

$k_{1}$
(Changed from that in NBS Report 10692 (Jan. 1972).)

$k(298)=5 \times 10^{-17} \mathrm{~cm}^{3}$ molecule ${ }^{-1} \mathrm{~s}^{-1}$. Estimated uncertainty: $\pm 50 \%$.

\section{Remarks}

The recommended rate is based on the data of $(c, d$, and g).

There are no satisfactory data on this reaction extending over a meaningful range of temperature. In the work of Johnston and Yost (c), rate constants were measured over the range 286 to $302 \mathrm{~K}$. The accuracy of the temperature measurements was stated to be \pm 2 degrees. From these data they derived the Arrhenius expression $k=1 \times 10^{-11} \exp \left(-3.5 \times 10^{3} / T\right) \mathrm{cm}^{3}$ molecule $^{-1} \mathrm{~s}^{-1}$. Although the pre-exponential factor appears to be reasonable, the uncertainty in the data makes an extrapolation to $220 \mathrm{~K}$ extremely unreliable. An uncertainty of $10^{ \pm 1}$ is therefore attached to the value of the rate constant at $220 \mathrm{~K}$, about $10^{-18} \mathrm{~cm}^{3}$ molecule $\mathrm{s}^{-1}$.

The other reported values $(d, g)$ for the rate constant are all near room temperature. The preferred value at $298 \mathrm{~K}$ is an average of these values and that predicted by the Arrhenius expression given in (c). At present not enough data is available to make a clear choice of the "best" value at $298 \mathrm{~K}$. These data $(\mathrm{d}, \mathrm{g})$ however confirm the approximate correctness of the data of (c) near room temperature, and in turn the reasonableness of the derived Arrhenius expression.

In these studies, reaction (1) was assumed to be followed by the reaction: $\mathrm{NO}_{2}+\mathrm{NO}_{3} \rightarrow \mathrm{N}_{2} \mathrm{O}_{5}$. Information on the overall stoichiometry, however, is available only in (d), where only two of six runs matched the assumed 
stoichiometry, i.e. $\Delta\left[\mathrm{NO}_{2}\right] / \Delta\left[\mathrm{O}_{3}\right]=2$. Values of this quantity ranged from 0.9 to 4.8 . Thus the interpretation of (c) and (d) is uncertain.

The result in (e) is based on widely scattered data and an assumed stoichiometry determined by a seven-step mechanism for the flash photolysis of $\mathrm{O}_{3}$ in presence of $\mathrm{N}_{2} \mathrm{O}$.

\section{References}

(a) D. D. Wagman, et al., NBS. Technical Note 270-3 (Jan. 1968).

(b) D. R. Stull and H. Prophet, JANAF Thermochemical Tables, 2d Ed,
Nat. Stand. Ref. Data Ser., Nat. Bur. Stand. (U.S.), 37 (June 1971).

(c) H. S. Johnston and D. M. Yost, J. Chem. Phys. 17, 386 (1949).

(d) H. W. Ford, G. J. Doyle, and N. Endow, J. Chem. Phys. 26, 1336 (1957).

(e) P. M. Scott, K. F. Preston, R. J. Andersen, and L. M. Quick, Can. J. Chem. 49, 1808 (1971).

(f) D. H. Stedman and H. Niki, preprint, 1972.

(g) H. Niki, private communication to D. Garvin, 1972.

\section{R. E. Huie, J. T. Herron}

January, 1972

Revised: January, 1973

\subsection{The Reaction Between $\mathrm{N}_{2} \mathrm{O}$ and $\mathrm{O}\left({ }^{1} D\right)$}

\begin{tabular}{l|lll}
\hline \hline & \multicolumn{3}{c}{$\Delta H_{298}^{\circ}(\mathrm{a}, \mathrm{b})$} \\
\hline $\mathrm{N}_{2} \mathrm{O}+\mathrm{O}\left({ }^{1} D\right) \rightarrow \mathrm{N}_{2}+\mathrm{O}_{2}$ & $-521.0 \mathrm{~kJ} / \mathrm{mol}$ & $(-124.52 \mathrm{kcal} / \mathrm{mol})$ & $k_{1 \mathrm{a}}$ \\
$\mathrm{N}_{2} \mathrm{O}+\mathrm{O}\left({ }^{(} D\right) \rightarrow 2 \mathrm{NO}$ & -340.5 & $(-81.38)$ & $k_{\mathrm{tb}}$ \\
\hline
\end{tabular}

Auxiliary Data

Reaction (1) has been studied in relative rate experiments only. Comparison reactions are:

\begin{tabular}{l|lll}
\hline & & \multicolumn{3}{|c}{} & $\Delta \mathrm{H}_{98}^{\circ}(\mathrm{a}, \mathrm{b})$ & \\
\hline $\mathrm{O}\left({ }^{1} D\right)+\mathrm{O}_{2} \rightarrow \mathrm{O}\left({ }^{3} P\right)+\mathrm{O}_{2}$ & $-189.8 \mathrm{~kJ} / \mathrm{mol}$ & $(-45.36 \mathrm{kcal} / \mathrm{mol})$ & $k_{2}$ \\
$\mathrm{O}\left({ }^{D} D\right)+\mathrm{O}_{3} \rightarrow 2 \mathrm{O}_{2}$ & -581.6 & $(-139.01)$ & $k_{3}$ \\
\hline
\end{tabular}

In addition to the reactions with $\mathrm{O}_{2}$ and $\mathrm{O}_{3}$ for which absolute values of the rate constants are available, reaction (1) has been studied in competition with the deactivation or reaction of $\mathrm{O}\left({ }^{1} D\right)$ with the following species: $\mathrm{N}_{2}, \mathrm{CO}, \mathrm{CO}_{2}, \mathrm{H}_{2}, \mathrm{H}_{2} \mathrm{O}, \mathrm{NO}, \mathrm{NO}_{2}, \mathrm{Xe}, \mathrm{CH}_{4}$, and neopentane.

$$
\text { Data }
$$

Note: Only the data comparing $k_{1}$ with $k_{2}$ or $k_{3}$ are given here. They are chosen from the very large set of data for relative values for $k\left(\mathrm{O}\left({ }^{1} D\right)+\mathrm{N}_{2} \mathrm{O}\right)$ (37 measured values of 12 ratios) because absolute values have been measured only for $k_{2}(\mathrm{j})$ and $k_{3}(\mathrm{k}, \mathrm{q})$.

\begin{tabular}{l|l}
\hline \hline \multicolumn{1}{c|}{$\left(k_{1 \mathrm{a}}+k_{1 \mathrm{~b}}\right) / k_{2}$} & \multicolumn{1}{c}{ Conditions } \\
\hline 2.8 & $\begin{array}{l}\sim 250 \mathrm{~nm} \text { photolysis of } \mathrm{O}_{3} ; \text { decrease in } \\
\text { yield of } \mathrm{N}_{2} \text { measured. } \\
\text { Scott, Cretanovic, 1971 (ref. c). } \\
228.8 \mathrm{~nm} \text { photolysis of } \mathrm{NO}_{2} ; \text { decrease in } \\
\text { yield of } \mathrm{N}_{2} \text { measured. } \\
\text { Paraskevopoulos, et al., 1971 (ref. d). } \\
147.0 \mathrm{~nm} \text { photolysis of } \mathrm{O}_{2} ; \text { change in yield } \\
\left.\text { of } \mathrm{O}^{(3 P}\right) \text { measured. } \\
\text { Young, et al., 1968 (ref. e). } \\
253.7 \mathrm{~nm} \text { photolysis of } \mathrm{O}_{3} ; \text { change in yield } \\
\text { of } \mathrm{N}_{2} \mathrm{O}_{5} \text { measured. }\end{array}$ \\
\hline 5.0 &
\end{tabular}

Data-Continued

\begin{tabular}{|c|c|}
\hline$\left(k_{\mathrm{s}}+k_{1 \mathrm{~b}}\right) / k_{2}$ & Conditions \\
\hline 3.6 & $\begin{array}{l}\text { De More, } 1970 \text { (ref. } \mathrm{f}) . \\
\text { Quenching of radiation from } \mathrm{O}_{2}\left({ }^{1} \Sigma \text { ) in } 254\right. \\
\text { nm photolysis of } \mathrm{O}_{3} . \\
\text { Gauthier, Snelling, } 1972 \text { (ref. } \mathrm{n} \text { ). }\end{array}$ \\
\hline$\left(k_{1 \mathrm{a}}+k_{1 \mathrm{~b}}\right) / k_{3}$ & $+\cdots$ \\
\hline 0.39 & $\begin{array}{l}254 \mathrm{~nm} \text { photolysis of } \mathrm{O}_{3} \text { in presence of } \mathrm{N}_{2} \mathrm{O} \text {; } \\
\quad \phi\left(\mathrm{N}_{2}\right) \text { measured. } \\
\text { Goldman, et al., } 1971 \text { (ref. i). }\end{array}$ \\
\hline $0.25-0.67$ & $\begin{array}{l}\text { Photolysis of } \mathrm{O}_{3} \text { in presence of } \mathrm{N}_{2} \mathrm{O} \text { at } 228.8 \text {, } \\
254 \text {, and } 280 \mathrm{~nm}, \Phi\left(-\mathrm{O}_{3}\right) \text { measured. }\end{array}$ \\
\hline & Lissi, Heicklen, 1972 (ref. o) \\
\hline$k_{1 \mathrm{a}} / k_{1 \mathrm{~b}}$ & \\
\hline $1.01 \pm 0.06$ & $\begin{array}{l}\mathrm{NO}_{2} \text { photolysis at } 228.8 \text { and } 242 \mathrm{~nm} \text {, yields } \\
\text { of } \mathrm{NO} \text { and } \mathrm{N}_{2} \text { measured. }\end{array}$ \\
\hline $0.99 \pm 0.06$ & $\begin{array}{l}\mathrm{O}_{3} \text { photolysis at } \sim 250 \mathrm{~nm} \text {, yields of } \mathrm{NO}_{2} \\
\text { and } \mathrm{N}_{2} \text { measured. }\end{array}$ \\
\hline
\end{tabular}

Scott, et al., 1971 (ref. g).

$0.59 \pm 0.01$

$\mathrm{N}_{2} \mathrm{O}$ photolysis at $213.9 \mathrm{~nm}$, quantum yield of $\mathrm{O}_{2}$ measured.

Greenberg, Heicklen, 1970 (ref. h).

$0.50 \pm 0.1 ; 0.59 \pm 0.1 \quad \mathrm{O}_{3} / \mathrm{N}_{2} \mathrm{O}$ mixture photolysis at 228.8 and at $253.7 \mathrm{~nm}, \phi\left(\mathrm{N}_{2}\right)$ meas.

Goldman, et al, 1971 (ref. i).

$0.69 \pm 0.05$

$\mathrm{N}_{2} \mathrm{O}$ photolysis at $213.9 \mathrm{~nm}$ and $184.9 \mathrm{~nm}$. Measured $\Phi\left(\mathrm{N}_{2}\right) / \Phi_{m}\left(\mathrm{O}_{2}\right)$ where $\Phi_{m}\left(\mathrm{O}_{2}\right)$ is the measured quantum yield of $\mathrm{O}_{2}$ formation.

$0.83 \pm 0.06$

Same system as above with excess $\mathrm{He}$ added to remove translational energy of $\mathrm{O}\left({ }^{1} \mathrm{D}\right)$.

Simonaitis, Greenberg, Heicklen, 1972 (ref. $\mathrm{m})$. 
Preferred Values (300 K)

(Changed from that in NBS Report 10828 (April 1972).)

$$
\begin{aligned}
& \text { Ratios }(p) \\
& k_{1}\left(\mathrm{~N}_{2} \mathrm{O}\right) / k_{2}\left(\mathrm{O}_{2}\right)=2.9 . \\
& k_{1}\left(\mathrm{~N}_{2} \mathrm{O}\right) / k_{3}\left(\mathrm{O}_{3}\right)=0.44 \\
& k_{1 \mathrm{a}} / k_{1 \mathrm{~b}}=1.0
\end{aligned}
$$

Absolute Values

$$
\begin{aligned}
& k_{1}=2.2 \times 10^{-10} \mathrm{~cm}^{3} \text { molecule }{ }^{-1} \mathrm{~s}^{-1} . \\
& k_{1 \mathrm{a}}=1.1 \times 10^{-10} . \\
& k_{1 \mathrm{~b}}=1.1 \times 10^{-10} .
\end{aligned}
$$

Uncertainty: $\log k \pm 0.1$.

\section{Remarks}

The preferred values for $k_{1} / k_{2}, k_{1} / k_{3}$, and $k_{1}$ are those developed by Cvetanovic (p) from an analysis of all rate ratio data for reactions of $\mathrm{O}\left({ }^{1} D\right)$.

This consisted of an evaluation of all data available in Nov. 1972 for reactions of $\mathrm{O}\left({ }^{1} D\right)$ with $\mathrm{CH}_{4}, \mathrm{C}_{2} \mathrm{H}_{6}$, $\mathrm{C}_{3} \mathrm{H}_{8}$, neopentane, $\mathrm{CO}, \mathrm{CO}_{2}, \mathrm{H}_{2}, \mathrm{H}_{2} \mathrm{O}, \mathrm{N}_{2}, \mathrm{NO}, \mathrm{NO}_{2}$, $\mathrm{N}_{2} \mathrm{O}, \mathrm{O}_{2}, \mathrm{O}_{3}$, and the rare gases. These rate ratio data form an interconnected network, the solution to which yields a self-consistent set of rate ratios. This data network is displayed in fig. 1. The relative rates pertinent to the data listed in this data sheet are: $1.0\left(\mathrm{CO}_{2}\right), 1.22\left(\mathrm{~N}_{2} \mathrm{O}\right), 0.42\left(\mathrm{O}_{2}\right), 2.8\left(\mathrm{O}_{3}\right), 0.30\left(\mathrm{~N}_{2}\right)$, $0.42(\mathrm{CO}), \quad 1.61\left(\mathrm{H}_{2}\right), \quad 1.95\left(\mathrm{H}_{2} \mathrm{O}\right), 1.17(\mathrm{NO}), 1.55\left(\mathrm{NO}_{2}\right)$, $0.78(\mathrm{Xe}), 2.22\left(\mathrm{CH}_{4}\right), 6.8$ (neopentane).

$k_{1 \mathrm{a}} / k_{1 \mathrm{~b}}$ value in $(\mathrm{g})$ selected as best value for thermally equilibrated $\mathrm{O}\left({ }^{1} D\right)$ atoms.

\section{Comments on Measurements}

Ref. (e)

Relative values put on an "absolute" basis by taking $k_{3}$ to be the mean of estimated upper and lower limits. Reported value for overall rate agrees with value chosen here for $\left(k_{1}+k_{2}\right)$.

Ref. ( $g$ )

From the limiting relative $\phi\left(\mathrm{N}_{2}\right)$ at high additive pressure in the $228.8 \mathrm{~nm}$. photolysis of $\mathrm{N}_{2} \mathrm{O}$, the value of $k_{1} /\left(k_{2}+k_{d}\right)$ was estimated to be $1.08 \pm 0.19$, where $k_{d}$ is the rate constant for the deactivation of $\mathrm{O}\left({ }^{1} D\right)$ by $\mathrm{N}_{2} \mathrm{O}$. They take this as confirmation of the two reported values of $\left(k_{1} / k_{2}\right)$ and also as an indication that $k_{d}$ is small relative to $k_{2}$.

Ref. $(h)$

A less precise value of $k_{1} / k_{2}=1.04(+0.59,-0.37)$ based on $\Phi\left(\mathrm{N}_{2}\right)$ also reported.

Ref. $(m)$

Authors conclude that value of $k_{1} / k_{2}=0.65 \pm 0.07$ for $O\left({ }^{1} D\right)$ atoms possessing greater than $10 \mathrm{kcal} / \mathrm{mol}$ translational energy and that for thermal $\mathrm{O}\left({ }^{1} D\right)$ atoms $k_{1} / k_{2}=0.90 \pm 0.10$.

\section{References}

(a) D. D. Wagman, et al., NBS Technical Note 270-3.

(b) C. E. Moore, NBS Circular 467, vol 1 (1949).

(c) P. M. Scott and R. J. Cvetanovic, J. Chem. Phys. 54, 1440 (1971).

(d) G. Paraskevopoulos, K. F. Preston, and R. J. Cvetanovic, J. Chem. Phys. 54, 3907 (1971).

(e) R. A. Young, G. Black, and T. G. Slanger, J. Chem. Phys. 49, 4758 (1968).

(f) W. B. DeMore, J. Chem. Phys. 52, 4309 (1970).

(g) P. M. Scott, K. F. Preston, R. J. Andersen, and L. M. Quick, Can. J. Chem. 49, 1808 (1971).

(h) R. I. Greenberg and J. Heicklen, Int. J. Chem. Kin. 2, 185 (1970).

(i) C. S. Goldman, R. I. Greenberg, and J. Heicklen, Int. J. Chem. Kin. 3, 501 (1971).

(j) J. F. Noxon, J. Chem. Phys. 52, 1852 (1970).

(k) R. Gilpin, H. I. Schiff, and K. H. Welge, J. Chem. Phys. 55, 1087 (1971).

(I) G. Paraskevopoulos and R. J. Cvetanovic, Chem. Phys. Lettrs. 9, 603 (1971).

(m) R. Simonaitis, R. I. Greenberg, and J. Heicklen, Int. J. Chem. Kin. 4, 497 (1972).

(n) M. Gauthier and D. R. Snelling, letters to R. F. H. and D. G. (1972).

(o) E. Lissi and J. Heicklen, J. Photochem. 1, 39 (1972).

(p) R. Cvetanovic, The Reactions of $\mathrm{O}\left({ }^{1} D_{2}\right)$, in The Natural Stratosphere, E. Reiter, editor (Climatic Impact Assessment Program, Monograph 1), preliminary draft, Nov. 1972.

(q) R. F. Heidner, D. Husain, and J. R. Wiesenfeld, Chem. Phys. Lettr. 16, 488 (1972).

R. F. Hampson

March, 1972

Revised: January, 1973

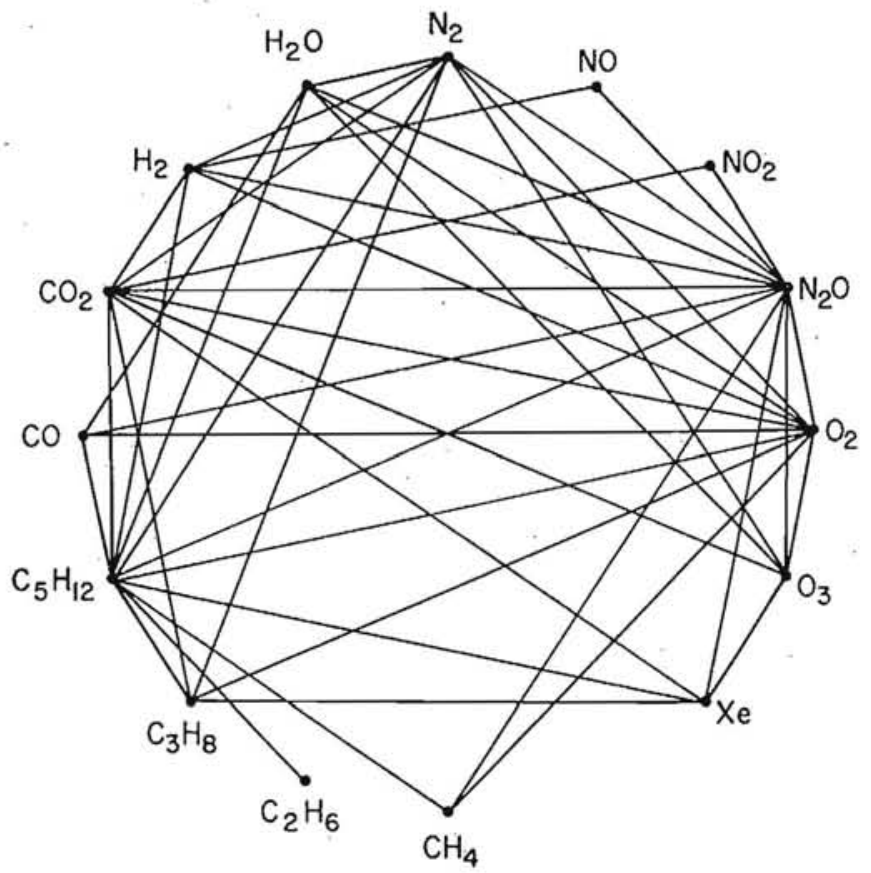

FIGURE 1. Rate ratio network for $O\left({ }^{1} D\right)$ reactions. Each line indicates that the ratio of the rates of reaction of $O\left({ }^{1} D\right)$ with the two species has been measured, e.g. the measured ratio $k\left(\mathrm{O}^{*}+\mathrm{O}_{3}\right) / k\left(\mathrm{O}^{*}+\mathrm{N}_{2} \mathrm{O}\right)$ is indicated by a line between $\mathrm{O}_{3}$ and $\mathrm{N}_{2} \mathrm{O}$. 


\subsection{The Reaction of Oxygen Atoms with Ozone}

\begin{tabular}{l|c|c}
\hline \hline \multirow{2}{*}{} & \multicolumn{2}{|c}{$\Delta H_{298}^{\circ}$ (a) } \\
\cline { 2 - 3 } & $\mathrm{kJ} \mathrm{mol}^{-1}$ & $\mathrm{kcal} \mathrm{mol}{ }^{-1}$ \\
\hline $\mathrm{O}\left({ }^{(P}\right)+\mathrm{O}_{3} \rightarrow \mathrm{O}_{2}+\mathrm{O}_{2}$ & -391.6 & $-93.6 \cdots k_{3}^{*}$ \\
\hline
\end{tabular}

${ }^{*}$ For $k_{1}, k_{2}$, and $k_{3}$ the numbering used in NSRDS-NBS 20 (ref. b) is maintained in these data sheets.

\section{Auxiliary Data}

\begin{tabular}{l|cc}
\hline \hline \multicolumn{3}{c|}{ Related reactions } \\
\hline & \multicolumn{1}{c}{$\Delta H_{298}^{\circ}$} \\
\hline $\mathrm{O}_{3}+\mathrm{M} \rightarrow \mathrm{O}\left({ }^{3} P\right)+\mathrm{O}_{2}+\mathrm{M} \quad 106.3 \mathrm{~kJ} \mathrm{~mol}^{-1}$ & \multicolumn{1}{c}{$25.4 \mathrm{kcal} \mathrm{mol}^{-1}$} & $k_{1}$ \\
$\mathrm{O}\left({ }^{3} P\right)+\mathrm{O}_{2}+\mathrm{M} \rightarrow \mathrm{O}_{3}+\mathrm{M}-106.3$ & -25.4 & $k_{2}$ \\
$\mathrm{O}\left({ }^{(} P\right)+\mathrm{OCS} \rightarrow \mathrm{CO}+\mathrm{SO}-211.3$ & -50.5 & $k_{4}$ \\
\hline
\end{tabular}

Equilibrium constant: $K_{12}=k_{1} / k_{2}$

$\log _{10} K_{12}=25: 565-5.422(1000 / \mathrm{T})$ molecules $\mathrm{cm}^{-3}$ (table III)

\section{Data}

Direct measurements

\begin{tabular}{l|l}
\hline$k$ in $\mathrm{cm}^{3}$ molecule ${ }^{-1} \mathrm{~s}^{-1}$ & \\
\hline $\log k_{3}$ (range) & Shock wave decomposition of \\
-11.62 to -12.19 & $\mathrm{O}_{3}, 769-910 \mathrm{~K} .\left[\mathrm{O}_{3}\right]$ vs time \\
& meas. See table I.
\end{tabular}

$k_{3}=(1.05 \pm 0.18) \times 10^{-11}$

$\exp \left[(-2.169 \pm 0.05) \times 10^{3} / T\right]$

Uncertainties: $1 \sigma$

$k_{3}(298)=7.5 \pm 0.6 \times 10^{-15}$

$k_{3}=(1.46 \pm 0.06) \times 10^{-14}$ at $296.4 \mathrm{~K}$

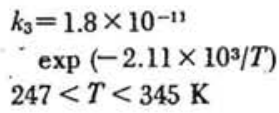

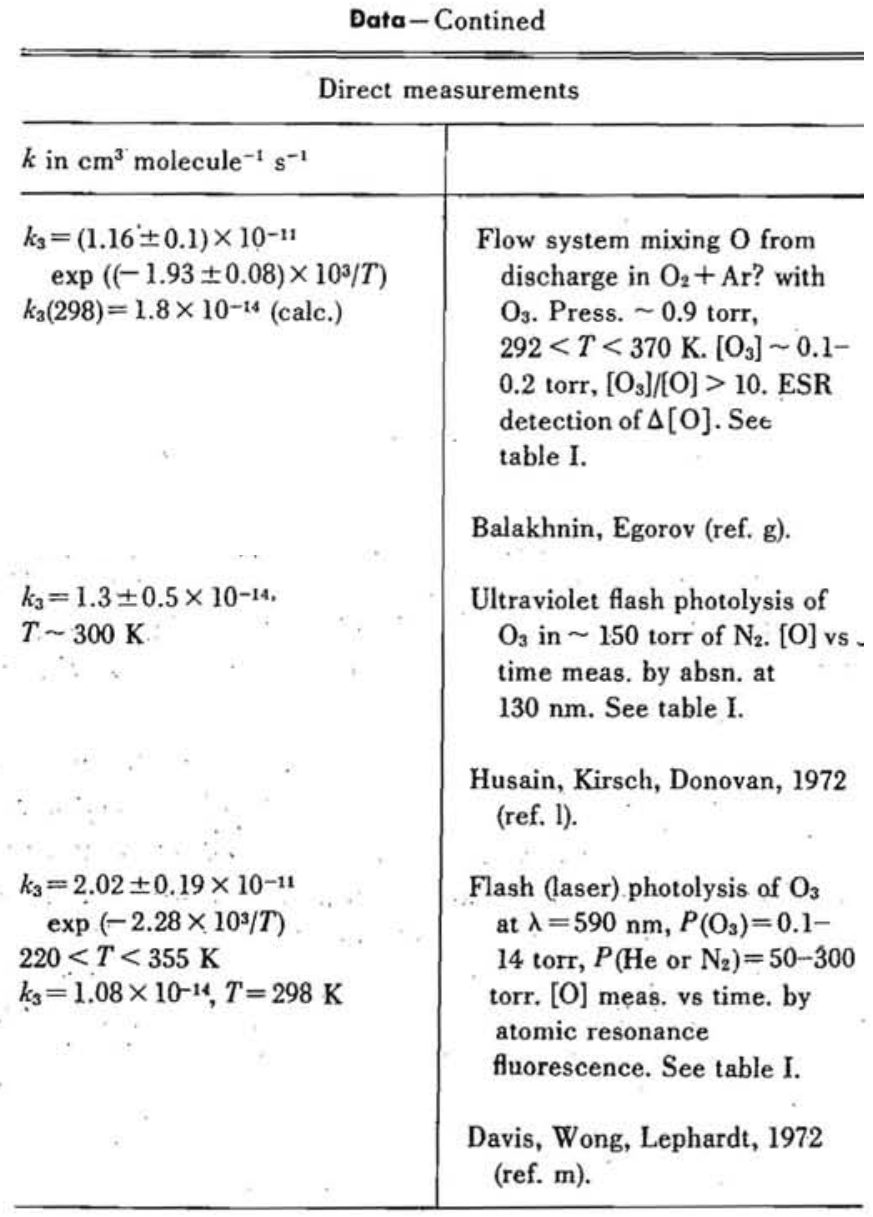

Indirect measurements in the ozone-oxygen system, $k_{2} / k_{3}$ and

Jones, Davidson, 1962 (ref. c).

Flow system mixing $\mathrm{O}, \mathrm{O}_{3}$, $\mathrm{Ar}$, and small amounts of NO. 269-409 K. Chemi: luminescence of $\mathrm{O}+\mathrm{NO}$ meas. vs distance. See table I.

McCrumb, Kaufman, 1971 (ref. d).

Flow system, mixed $\mathrm{Ar}, \mathrm{O}_{3}$, $\mathrm{N}_{2} \mathrm{O}$, and $\mathrm{O}$, with $\mathrm{O}$ produced by decomposition of $\mathrm{N}_{2} \mathrm{O}$ on Nernst glower. Calorimetric detection of $\mathrm{O}$ atoms.

Lundell, et al., 1969 (ref. e).

Quotation, no data points available.

Schiff, 1972 (ref. f).
Indirect measurements in the ozone-oxy
\[ k_{J}=k_{1} k_{3} / k_{2} \]

\begin{tabular}{l|c}
\hline$k_{2} / k_{3}=2.31_{5} \times 10^{-24} \times$ & Data evaluation, based on $k_{1}$, \\
$\exp \left(+3.47 \times 10^{3} / T\right)$ & $k_{2}, k_{2} / k_{3}, k_{J}$ and $k_{3}$. See ref. \\
$\mathrm{cm}^{3}$ molecule & (b) for tables of data. Un- \\
$200<T<900$ & certainties are evaluator's \\
Uncertainty: $\log \left(k_{2} / k_{3}\right) \pm 0.3$ & overall estimates.
\end{tabular}

$k_{s}=7.16 \times 10^{14} \times$

$\exp \left(-14.9 \times 10^{3} / T\right) \mathrm{s}^{-1}$

$200<T<900 \mathrm{~K}$

Johnston, 1968 (ref. b).

Uncertainty: $\log k_{j} \pm 0.3$

$k_{J}=(1.7 \pm 0.5) \times 10^{14} \times$

$\exp \left[(-14.14 \pm 0.1) \times 10^{3} / T\right]$

$409<T<449 \mathrm{~K}$

Uncertainty: $1 \sigma$

Thermal decomposition of $\mathrm{O}_{3}$ $\left(\sim 2.5 \%\right.$ in $\left.\mathrm{O}_{2}\right)$ at atmos. pheric pressure. $\Delta \mathrm{O}_{3}$ and $\Delta t$ measured. $k_{J}$ recalculated here from points and $k_{1}$. See table II.

Intezarova, Kondratiev, 1967 (ref. h).

Indirect measurements not in the ozone-oxygen system

\begin{tabular}{|c|c|c|}
\hline$k_{3} / k_{4}$ & $T, \mathrm{~K}$ & Steady photolysis of $\mathrm{O}_{3}$ in $\mathrm{O}_{3} /$ \\
\hline $0.92 \pm 0.03$ & 197 & OCS mixtures. $\phi(\mathrm{CO})$ and \\
\hline $1.28 \pm 0.10$ & 228 & $\phi\left(\mathrm{CO}_{2}\right)$ measured. Values \\
\hline $0.86 \pm 0.04$ & 273 & recalculated here. \\
\hline
\end{tabular}

$0.88 \pm 0.02 \quad 298$

Average: 0.98

Krezenski, et al., 1971 (ref. i). 
Data-Continued

\begin{tabular}{|c|c|}
\hline$k$ in $\mathrm{cm}^{3}$ molecule $\mathrm{e}^{-1} \mathrm{~s}^{-1}$ & \\
\hline \multicolumn{2}{|c|}{ Data evaluations } \\
\hline $\begin{array}{l}k_{3}=2.00 \times 10^{-11} \\
\quad \exp \left(-2.41 \times 10^{3} / T\right) \\
\quad \text { for } 200<T<1000\end{array}$ & $\begin{array}{l}\text { Data evaluation based on meas- } \\
\text { surements for } k_{1}, k_{2} \text {, and } \\
k_{3} \text { and } K_{\mathrm{eq}}=k_{1} / k_{2}\end{array}$ \\
\hline Uncertainty: $\log k_{3} \pm 0.2$ & Johnston, 1968 (ref. b). \\
\hline $\begin{array}{l}k_{3}=1.9 \times 10^{-11} \\
\quad \exp \left(-2.3 \times 10^{3} / T\right) \\
220<T<1000\end{array}$ & $\begin{array}{l}\text { Data evaluation based on } \\
\text { references c, d, } 1 \text {, and } \mathrm{m} \text {. }\end{array}$ \\
\hline Uncertainty $\log k_{3} \pm 0.1$ & $\begin{array}{l}\text { Davis, Johnston, Schiff, } 1972 \\
\text { (ref n). }\end{array}$ \\
\hline
\end{tabular}

Preferred Value

(Changed from that in NBS Report 10828 (April 1972).)

$k_{3}=1.9 \times 10^{-11} \exp \left(-2.3 \times 10^{3} / T\right) \mathrm{cm}^{3}$ molecule ${ }^{-1} \mathrm{~s}^{-1}$. $E^{*}=19.1 \mathrm{~kJ} \mathrm{~mol}^{-1} \quad\left(4.57 \mathrm{kcal} \mathrm{mol}^{-1}\right)$.

Uncertainty $\log k_{3} \pm 0.1$.

\section{Remarks}

Recent direct measurements of $k_{3}$ (d, e, g, l, m) provide data over the range $220-410 \mathrm{~K}$. In this temperature range only rate ratios, $k_{2} / k_{3}$, were available in 1968 when the ozone data were evaluated by Johnston (b). The preferred value, which is the evaluation by Davis et al. (n), takes into account the new measurements. It is based solely on the direct measurements $(c, d, 1, m)$. It emphasizes the low temperature work and uses those near $1000 \mathrm{~K}$ (c) only to extend the temperature range.

A least squares fit to the data in table I, excluding those from (g), gives the same result. This $k_{3}$ passes through the center of the high temperature data (c) and lies between the results in $(\mathrm{d}, \mathrm{m})$. The net result of the new evaluation is to Iower the activation energy by about $0.9 \mathrm{~kJ}(0.2 \mathrm{kcal})$ and reduce the error bounds. These are now $\log k_{3} \pm 0.1$ or $k_{3} \pm 25$ percent. They define a range about equal to the spread between the data reported in $(d)$ and $(m)$.

A caveat is in order. These error limits may be optimistic since the other low temperature data $(e, g, l)$ are all higher than those from (d) and ( $\mathrm{m}$ ) by factors of 1.5 to 2.5 in $k_{3}$. We believe these other studies are less reliable but that the total spread is not surprising since five different methods have been used.

No significance should be attached to the slightly different activation energies reported in various studies. Temperature coefficients are more likely to be affected by systematic errors than are absolute values of rate constants.

The overall situation is that there are now two quite consistent studies $(\mathrm{d}, \mathrm{m})$ of $k_{3}$ covering the temperature range $220-410 \mathrm{~K}$ and very rough measurements at $1000 \mathrm{~K}$. The latter should be repeated.

Ref. (b)

Evaluation of data available in 1967. Three rate constants $k_{1}, k_{2}$, and $k_{3}$ were derived using the following scheme, after it had been justified. In the chart below $k$ (obs) means data points, $k(T)$ a function. $K_{12}=k_{1} / k_{2}$, the equilibrium constant.

$k_{1}$ (obs) and $k_{2}$ (obs) $K_{12}(T) \rightarrow k_{1}(T)$.

$k_{1}(T) / K_{12} \rightarrow k_{2}(T)$.

$k_{3}$ (obs) and $k_{2}(T) /\left(k_{2} / k_{3}\right)$ (obs) and $k_{J}(\mathrm{obs}) / K_{12}(T) \rightarrow$ $k_{3}(T)$.

$\operatorname{Ref.}(c)$

These are the only high temperature measurements for $k_{3}$. They scatter badly. Undoubtedly higher precision could be obtained today with the same technique.

Ref. $(d)$

$\mathrm{O}$ atoms (produced by decomposition of $\mathrm{O}_{3}$ on a Nernst glower) reacted with $\mathrm{O}_{3}$. $\mathrm{NO}$ added (to monitor the $\mathrm{O}$-atom concentration). In all experiments $[\mathrm{NO}]<$ $[\mathrm{O}] \ll\left[\mathrm{O}_{3}\right]$. NO also reacts at an appreciable rate with $\mathrm{O}_{3}$ and decreases during the reaction. The simultaneous differential equations for the system were integrated and $k_{3}$ matched to the observed decay of [O]. This analysis is dependent upon the rate coefficients for $\mathrm{O}+\mathrm{NO}_{2} \rightarrow \mathrm{O}_{2}+\mathrm{NO}$ and $\mathrm{O}_{3}+\mathrm{NO} \rightarrow \mathrm{NO}_{2}+\mathrm{O}_{2}$. The scatter of the data is small, as shown by the range of rates at $298 \mathrm{~K}\left(0.62-0.84 \times 10^{-14}\right)$.

Ref. (e) and ( $f$ )

Wall effects (decay of $\mathrm{O}$ in the absence of $\mathrm{O}_{3}$ ) were observed (25 to $50 \%$ of overall rate). $\left[\mathrm{N}_{2} \mathrm{O}\right]$ probably equals 50-100 [O]. No production of NO was found in the pyrolysis of $\mathrm{N}_{2} \mathrm{O}$. This is contrary to the later experience reported in ref. (d). The two studies would agree if $[\mathrm{NO}] /[\mathrm{O}] \sim 0.4$ here. This would lower $k_{3}$. Other heat producing reactions would raise $k_{3}$. Schiff (private communication) believes that the uncertainty in [NO] could not be large enough to account for the discrepancy. $\mathrm{He}$ also states any likely impurity reactions would have very little effect on the temperature coefficient although they might raise the absolute value of the rate constant.

Ref. $(g)$

The information in this paper is insufficient to permit a detailed comparison with other work. Only by inferences drawn from other work by the same authors can the method, gas composition, and contact times be guessed at. The reported rates are 2 to 2.5 times faster than those of McCrumb and Kaufman (ref. d).

These data are not used here primarily because an electric discharge was used to produce the $\mathrm{O}$-atoms: there may be other energetic species present. (The objection may not be as valid as it is for some of the older work since, apparently, only a small percentage of $\mathrm{O}_{2}$ in $\mathrm{Ar}$ was passed through the discharge.) 
Ref. $(h)$

Experiments at constant mole fraction of $\mathrm{O}_{3}$ and constant (NTP) flow rate. Corrections made for reaction being in the intermediate region (both $k_{1}$ and $k_{J}$ important). Because of the constant input conditions and the sharply different percentage conversions at the ends of the temperature range, there could be substantial systematic errors that would affect the results. Authors report $k_{2} / k_{3}$ based on a selected $k_{1}=1.29 \times 10^{-9}$ $\exp \left(-11.75 \times 10^{3} / T\right)$ for $\mathrm{M}=\mathrm{O}_{2}$. Expression and points reported here (table II) are calculated $k_{J}=k_{1} k_{3} / k_{2}$ using their $k_{1}(T)$ and $k_{2} / k_{3}$ points. There are insufficient data in these experiments to permit extraction of both $k_{1}$ and $k_{2} / k_{3}$. Because $k_{2} / k_{3}$ is a correction term in the analysis, its value is probably less reliable than $k_{J}$. The temperature dependence of $k_{2} / k_{3}$ depends strongly on $k_{1}$. Using $\mathrm{K}_{\text {eq }}$ from table III this data set yields log $k_{3}=-11.34-0.73(1000 / T) \mathrm{cm}^{3}$ molecule $\mathrm{e}^{-1} \mathrm{~s}^{-1}$.

Ref. (i)

Values for $k_{3} / k_{4}$ recalculated from data in table IV, ref. (h), pooling all data at each temperature and fitting $\left[\phi(\mathrm{CO})+\phi\left(\mathrm{CO}_{2}\right)\right]^{-1}-1=k_{3}\left[\mathrm{O}_{3}\right] / k_{4}[\mathrm{OCS}]$ by least squares. We assign $k_{3} / k_{4}=0.98,197<T<298$. (Authors made a different fit, obtaining $k_{3} / k_{4}=0.98$, $1.05,0.925,0.901$ at 197, 228, 273, 298 and calculated $k_{3} / k_{4}=0.64 \exp (+100 / T)$.) The available data for reaction (4), measured $298-1100 \mathrm{~K}$ are not reliable enough to be extrapolated to lower temperatures. The reported $k_{3} / k_{4}$ should be used to establish $k_{4}$, not $k_{3}$. See ref. (i) for an analysis, based on the rate of $\mathrm{O}+1$-butene and 3 rate ratios that yields $k_{3}$ in agreement with ref. (d).

Ref. $(l)$

These experiments determine the rate of disappearance of O-atoms after flash photolysis of ozone. They were interpreted using the mechanism

$$
\begin{aligned}
& \mathrm{O}_{3}+h \nu \rightarrow \mathrm{O}\left({ }^{1} D\right)+\mathrm{O}_{2}\left({ }^{1} \Delta\right) \\
& \mathrm{O}\left({ }^{1} D\right)+\mathrm{N}_{2} \rightarrow \mathrm{O}+\mathrm{N}_{2} \\
& \mathrm{O}+\mathrm{O}_{3} \rightarrow 2 \mathrm{O}_{2} \\
& \mathrm{O}_{2}\left({ }^{1} \Delta\right)+\mathrm{O}_{3} \rightarrow \mathrm{O}+2 \mathrm{O}_{2} \\
& \mathrm{O}+X \rightarrow \text { products }
\end{aligned}
$$

$k_{5}$

$k_{1}$

$k_{6}$

$k_{7}$

where $X$ is impurities or walls. Corrections were made for $\mathrm{O}+\mathrm{O}$ and $\mathrm{O}+\mathrm{O}_{2}$ combination. Assuming reaction (5) converts all $\mathrm{O}\left({ }^{1} D\right)$ to $\mathrm{O}$, which is reasonable here, $[\mathrm{O}] \sim\left[\mathrm{O}_{2}\left({ }^{1} \Delta\right)\right]$ at $t=\mathrm{O}$ and the measured rate constant

is $k_{7}+\left(k_{1}-k_{6}\right)$. The final value of $k_{1}$ depends upor the choice for $k_{6}$, here $3 \times 10^{-15} \mathrm{~cm}^{3}$ molecule ${ }^{-1} \mathrm{~s}^{-1}$ and, indirectly, upon the absolute value of the absorption coefficient for $\mathrm{O}$-atoms. The undefined path, reaction (7) accounts for more than 50 percent of the $\mathrm{O}$-atom disappearance in 11 of 12 runs. These factors lead us to place little reliance upon the absolute value of $k_{1}$. The data are summarized as one point in table $\mathrm{I}$.

Ref. (m)

The rate constant was determined from the time history of $[\mathrm{O}]$ determined by atomic resonance fluorescence after flash photolysis of $\mathrm{O}_{3}$ at $590 \mathrm{~nm}$. This source produces only $\mathrm{O}\left({ }^{3} P\right)$. Variation of total pressure produced no change in $k$, indicating that combination reactions are unimportant. $\left[\mathrm{O}_{2}\right] \sim 0.06\left[\mathrm{O}_{3}\right]$. Precision of 11 percent claimed. The Arrhenius expression quoted in the data section is a weighted least squares fit.

\section{References}

(a) D. D. Wagman, et al., NBS Tech. Note 270-3 (1968).

(b) H. S. Johnston, Nat. Stand. Ref. Data Series-NBS 20 (1968).

(c) W. M. Jones and N. Davidson, J. Am. Chem. Soc. 84, 2868 (1962).

(d) J. L. McCrumb and F. Kaufman, J. Chem. Phys. 57, 1270 (1972).

(e) O. R. Lundell, R. D. Ketcheson, and H. I. Schiff, Symposium (International) on Combustion 12, 307 (1969).

(f) H. I. Schiff, Ann. Geophys. 28, 67 (1972), quoting unpublished work of Lundell, Ketcheson, and Schiff. A slightly different preliminary value was quoted in Can. J. Chem. 47, 1903 (1969).

(g) V. P. Balakhnin and V. I. Egorov, Kinetika y Kataliz 13, 282 (1972). Kinetics and Catalysis 13,255 (1972).

(h) E. I. Intezarova and V, I. Kondratiev, Bull. Acad. Sci. USSR, Div. Chem. Sci., p. 2326 (1967). (English translation of Izvest. Akad. Nauk SSSR, Ser. Khim., p. 2440 (1967)).

(i) D. C. Krezenski, R. Simonaitis, and J. Heicklen, Int. J. Chem. Kinetics 3,467.(1971).

(j) D. R. Stull and H. Prophet, JANAF Thermochemical Tables, 2d edition, Nat. Stand. Ref. Data Ser., Nat. Bur. Stand. (U.S.) 37 (June 1971).

(k) E. S. Castellano and H. J. Schumacher, Z. Phys. Chem. N. F. 34, 198 (1962).

(l) D. Husain, L. J. Kirsch, and R. J. Donovan, J. Photochem. 1, 69 (1972/73).

(m) D. D. Davis, W. Wong, and Lephardt, private communication, January, 1973.

(n) D. D. Davis, H. S. Johnston, and H. I. Schiff in The Natural Stratosphere, E. Reiter, editor (preliminary draft, Climatic Impact Assessment Program Monograph 1, November, 1972).

D. Garvin

April, 1972

Revised: January, 1973 
TABLE I. Observed values of $k_{3}, \mathrm{~cm}^{3}$ molecule ${ }^{-1} \mathrm{~s}^{-1}$. This table incorporates table 25, ref. (b), and the later measurements in refs. (d), (e), (g), (l) and (m).

\begin{tabular}{|c|c|c|c|c|c|c|c|c|c|}
\hline$T / \mathrm{K}$ & $1000 / T$ & M & $\log k_{3}$ & Ref. & $T / \mathrm{K}$ & $1000 / T$ & M & $\log k_{3}$ & Ref. \\
\hline 769 & 1.300 & \multirow{8}{*}{$\mathrm{Ar}$} & -11.98 & \multirow[t]{6}{*}{ (c) } & 330 & 3.030 & & -13.812 & \multirow[t]{11}{*}{ (d) } \\
\hline 812 & 1.230 & & -12.19 & & 338 & 2.956 & & -13.708 & \\
\hline 827 & 1.209 & & -11.89 & & 347 & 2.882 & & -13.728 & \\
\hline 840 & 1.190 & & -12.16 & & 359 & 2.786 & & -13.578 & \\
\hline 846 & 1.181 & & -11.85 & & 363 & 2.755 & & -13.587 & \\
\hline 876 & 1.140 & & -11.62 & & & & & & \\
\hline 910 & 1.098 & & -11.74 & & 378 & 2.646 & & -13.462 & \\
\hline & & & & & 384 & 2.604 & & -13.446 & \\
\hline 788 & 1.269 & \multirow[t]{4}{*}{$\mathrm{N}_{2}$} & -11.90 & \multirow[t]{4}{*}{ (c) } & 388 & 2.577 & & -13.424 & \\
\hline 831 & 1.202 & & -11.80 & & 409 & 2.445 & & -13.315 & \\
\hline 837 & 1.193 & & -11.87 & & & & & & \\
\hline 863 & 1.158 & & -11.82 & & 296.4 & 3.374 & & -13.836 & (e) \\
\hline 298 & -3.356 & \multirow{5}{*}{ Ar } & -14.102 & \multirow[t]{16}{*}{ (d) } & 292 & 3.424 & \multirow[t]{5}{*}{ Ar? } & -13.80 & \multirow[t]{5}{*}{ (g) } \\
\hline 298 & 3.356 & & -14.114 & & 311 & 3.215 & & -13.63 & \\
\hline 298 & 3.356 & & -14.114 & & 316 & 3.165 & & -13.56 & \\
\hline 298 & 3.356 & & -14.076 & & 334 & 2.994 & & -13.46 & \\
\hline 298 & 3.356 & & -14.137 & & 370 & 2.703 & & -13.19 & \\
\hline 298 & 3.356 & & -14.119 & & $\sim 300$ & 3.33 & \multirow[t]{2}{*}{$\mathrm{N}_{2}$} & -13.89 & \multirow{11}{*}{ (m) } \\
\hline 298 & 3.356 & & -14.149 & & & & & 10.09 & \\
\hline 298 & 3.356 & & -14.125 & & 220 & 4.545 & \multirow[t]{9}{*}{$\mathrm{He}$} & -15.222 & \\
\hline 298 & 3.356 & & -14.108 & & 240 & 4.167 & & -14.780 & \\
\hline 298 & 3.356 & & -14.180 & & 266 & 3.759 & & -14.439 & \\
\hline & & & & & 298 & 3.356 & & -13.979 & \\
\hline 298 & 3.356 & & -14.167 & & 298 & 3.356 & & -13.987 & \\
\hline 298 & 3.356 & & -14.208 & & 298 & 3.356 & & -13.947 & \\
\hline 269 & 3.717 & & -14.539 & & 353 & 2.833 & & -13.544 & \\
\hline 273 & 3.663 & & -14.457 & & 353 & 2.833 & & -13.527 & \\
\hline 314 & 3.185 & & -13.941 & & & & & & \\
\hline
\end{tabular}

$\log k_{3}=(-10.712 \pm 0.05)-(1.007 \pm 0.017)(1000 / T)$. Uncertainty: $1 \sigma$. Residual standard deviation: 0.11 .
$\mathrm{E}^{*}=18.8 \mathrm{~kJ} \mathrm{~mol}^{-1}\left(4.50 \mathrm{kcal} \mathrm{mol}^{-1}\right)$.

Data from ref. (g) were not used in deriving $\log k_{3}$ above.

TABLE II. Observed values of the Jahn rate constant, $k_{1} k_{3} / k_{2}$. This table supplements, but does not incorporate, table 22 , ref (b). $\log k_{3}$ was calculated using the equilibrium data in table III (2 constant equation).

\begin{tabular}{|c|c|c|c|c|c|c|c|c|c|}
\hline$T^{*}$ & $1000 / T$ & $\log k_{J}^{* *}$ & $\log k_{3}(\mathrm{calc})$ & Ref. & $T^{*}$ & $1000 / T$ & $\log k_{J}^{* *}$ & $\log k_{3}$ (calc) & Ref. \\
\hline 498 & 2.005 & 1.885 & -12.809 & (h) & 446 & 2.240 & 0.437 & -12.983 & \\
\hline 498 & 2.010 & 1.833 & -12.833 & $\mathrm{M}=\mathrm{O}_{2}$ & & & & & \\
\hline 485 & 2.060 & 1.611 & -12.784 & & 435 & 2.300 & 0.061 & -13.033 & \\
\hline 484 & 2.065 & 1.590 & -12.779 & & 435 & 2.300 & 0.083 & -13.011 & \\
\hline \multirow[t]{2}{*}{472} & 2.120 & 1.175 & -12.895 & & 429 & 2.330 & -0.104 & -13.036 & \\
\hline & & & & & 429 & 2.330 & -0.092 & -13.024 & . \\
\hline 472 & 2.120 & 1.195 & -12.875 & & 427 & 2.340 & -0.093 & -12.971 & \\
\hline 472 & 2.120 & 1.161 & -12.909 & & & & & & \\
\hline 467 & 2.140 & 1.041 & -12.921 & & 426 & 2.350 & -0.144 & -12.967 & \\
\hline 464 & 2.155 & 0.945 & -12.936 & & 425 & 2.355 & -0.260 & -13.056 & \\
\hline 458 & 2.185 & 0.794 & -12.924 & & 417 & 2.400 & -0.547 & -13.099 & \\
\hline & & & & & 417 & 2.400 & -0.535 & -13.087 & \\
\hline 458 & 2.185 & 0.852 & -12.866 & & 410 & 2.440 & -0.889 & -13.244 & \\
\hline 458 & 2.185 & 0.768 & -12.950 & - & & & & & \\
\hline 446 & 2.240 & 0.381 & -13.039 & & 409 & 2.445 & -0.879 & -13.127 & \\
\hline 446 & 2.240 & 0.423 & -12.997 & & 409 & 2.445 & -0.741 & -13.049 & \\
\hline
\end{tabular}


TABLE III. Equilibrium constant, $K_{1}$ for the reaction $\mathrm{O}_{3}=\mathrm{O}_{2}+\mathrm{O}$ (molecules $\mathrm{cm}^{-3}$ ) based on $\log K_{1}$ from the JANAF Tables (ref. $\mathrm{j}$ ) with additional points calculated at 188 and $250 \mathrm{~K}$. This replaces table 16 (ref. b) in which the points at 400 and $500 \mathrm{~K}$ are incorrect. The two functions, $\log K_{12}(T)$ have been recalculated, and are improved fits to the tabulated values.

\begin{tabular}{c|c|r}
\hline \hline$T$ & $1000 / T$ & \multicolumn{1}{c}{$\log K_{12}$} \\
\hline 188 & 5.319 & -3.271 \\
200 & 5.000 & -1.548 \\
250 & 4.000 & 3.866 \\
300 & 3.333 & 7.485 \\
400 & 2.500 & 12.018 \\
500 & 2.000 & 14.738 \\
600 & 1.6667 & 16.546 \\
700 & 1.429 & 17.831 \\
800 & 1.250 & 18.789 \\
900 & 1.111 & 19.528 \\
1000 & 1.000 & 20.117 \\
\hline
\end{tabular}

$\log K_{12}=25.565-5.422(1000 / T)$. Residual standard deviation: 0.014 . Range of deviations $+0.017(600 \mathrm{~K})$ to $-0.026(1000 \mathrm{~K})$.

$\log K_{12}=25.982-5.444(1000 / T)-0.136 \log T$. Residual standard deviation: 0.013 . Range of deviations $+0.0124(188 \mathrm{~K})$ to -0.0153 (at $250 \cdot \mathrm{K})$.

$\log K_{12} \equiv \log K_{p}-\log R T+\log N_{A}$, where $K_{p}$ is the thermodynamic equilibrium constant in atmospheres, $N_{A}=6.02 \times 10^{23}$ molecules $\mathrm{mol}^{-1}$ and $R=82.05 \mathrm{~cm}^{3}$ atm $\mathrm{mol}^{-1} \mathrm{~K}^{-1}$.

\subsection{Collisional Quenching of $\mathrm{O}_{2}\left(a^{1} \Delta g\right)$}

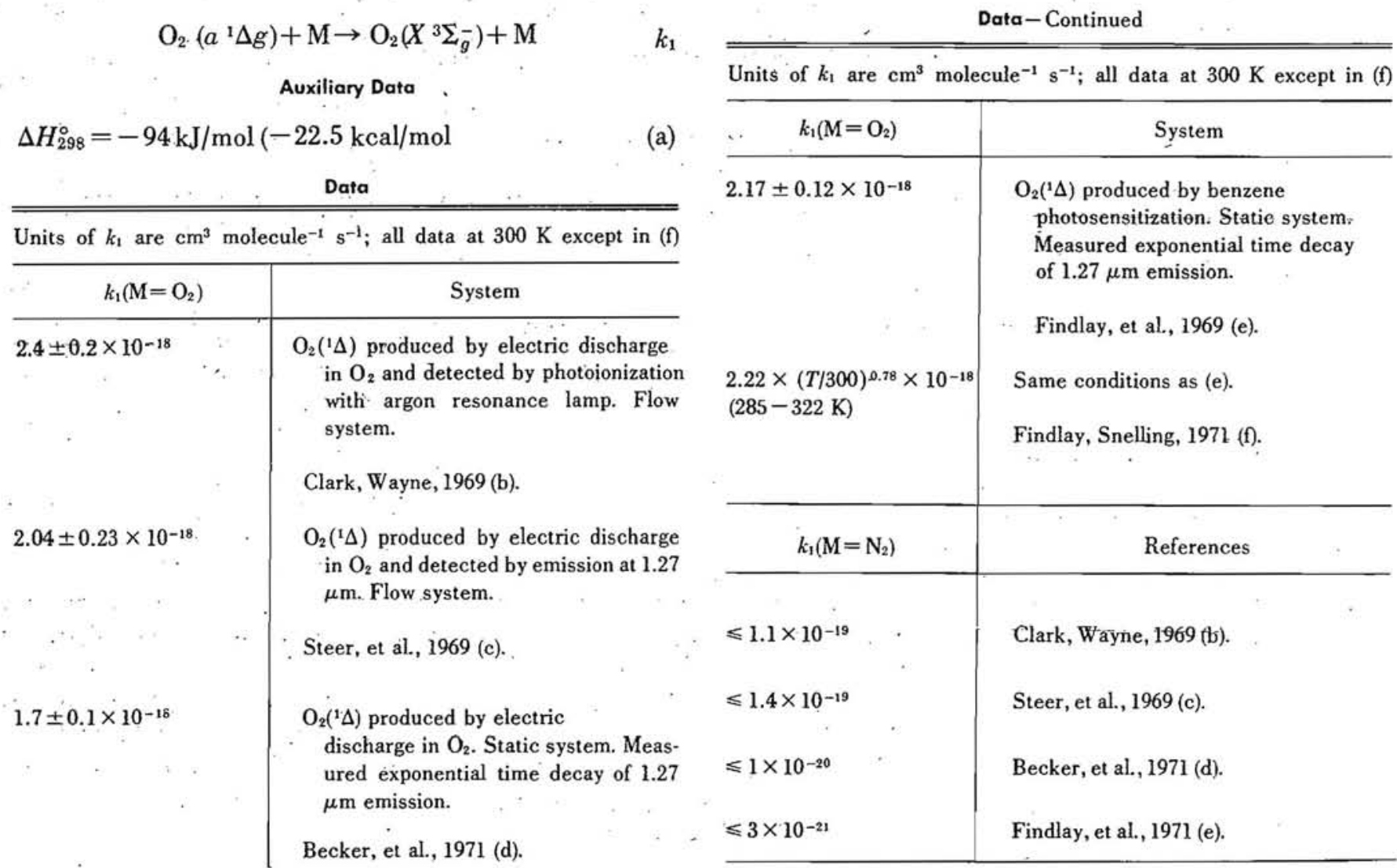




\section{Preferred Value}

$k_{1}\left(\mathrm{M}=\mathrm{O}_{2}\right)=2.2 \pm 0.5 \times(T / 300)^{0.8} \times 10^{-18} \mathrm{~cm}^{3}$ molecule ${ }^{-1} \mathrm{~s}^{-1}$, over temperature range $285-322 \mathrm{~K}$.

Estimated uncertainty in $k: \pm 25$ percent throughout this temp. range.

Although the temperature dependence has not been determined over a large temperature range, because this dependence is very small the above expression can probably be safely extrapolated to stratospheric temperatures.

$k_{1}\left(\mathrm{M}=\mathrm{N}_{2}\right) \leqslant 2 \times 10^{-20} \mathrm{~cm}^{3}$ molecule ${ }^{-1} \mathrm{~s}^{-1}$ at $300 \mathrm{~K}$.

\section{Remarks}

For $\mathrm{M}=\mathrm{O}_{2}$, all the recent room temperature measurements (b), (c), (d), (e), (f), are in good agreement. A simple average is given as the preferred rate at $300 \mathrm{~K}$ and the temperature dependence in $(f)$ is accepted. Preliminary data given in $(\mathrm{g})$ were not used nor were the earlier discordant data of $(\mathrm{h})$.

For $\mathrm{M}=\mathrm{N}_{2}$ values from $10^{-19}$ to $10^{-21}$ are reported. Only an upper limit is given here. Data in support of the lower value in (d) are not given in sufficient detail to permit reevaluation, and the very low value in (e) can not be substantiated by the data.

\section{References}

(a) G. Herzberg, Spectra of Diatomic Molecules, D. Van Nostrand, Princeton, N.J., 1950.

(b) I. D. Clark and R. P. Wayne, Proc. Roy. Soc. (London) A314, 111 (1969).

(c) R. P. Steer, R. A. Ackerman, and J. N. Pitts, Jr., J. Chem. Phys. 51, 843 (1969).

(d) K. H. Becker, W. Groth, and U. Schurath, Chem. Phys. Letters 8, 259 (1971)

(e) F. D. Findlay, C. J. Fortin, and D. R. Snelling, Chem. Phys, Letters 3, 204 (1969).

(f) F. D. Findlay and D. R. Snelling, J. Chem. Phys. 55, 545 (1971).

(g) I. D. Clark and R. P. Wayne, Chem. Phys. Letters 3, 93 (1969). Superseded by (b).

(h) A. M. Winer and K. D. Bayes, J. Phys. Chem. 70, 302 (1966).

J. T. Herron, R. E. Huie

March 1972

\subsection{Collisional Quenching of $\mathrm{O}_{2}\left({ }^{1} \Sigma_{g^{+}}\right)$}

$\mathrm{O}_{2}\left(\mathrm{~b}^{1} \Sigma_{g^{+}}\right)+\mathrm{M} \rightarrow \mathrm{O}_{2}\left({ }^{3} \Sigma_{g^{-}}^{-}\right)+\mathrm{M}$

Auxiliary Data

$\Delta H^{\circ}{ }_{298}=-157 \mathrm{~kJ} \mathrm{~mol}^{-1}\left(-37.5 \mathrm{kcal} \mathrm{mol}^{-1}\right)$

Data

Units of $k$ are $\mathrm{cm}^{3}$ molecule $\mathrm{e}^{-1} \mathrm{~s}^{-1}$; all data at $300 \mathrm{~K} ;\left(\mathrm{O}_{2}\left({ }^{1} \Sigma\right)\right)$ determined from intensity of $762 \mathrm{~nm}$ emission $\left(\mathrm{b}^{1} \Sigma-X^{3} \Sigma\right)$

\begin{tabular}{|c|c|}
\hline$k_{1}\left(\mathrm{M}=\mathrm{O}_{2}\right)$ & Conditions \\
\hline $1.5 \pm 0.5 \times 10^{-16}$ & $\begin{array}{l}\mathrm{O}_{2}\left({ }^{1} \Sigma\right) \text { produced by vacuum uv photolysis } \\
\text { of } \mathrm{O}_{2} \text { to give } \mathrm{O}\left({ }^{1} D\right) \text {, then } \mathrm{O}\left({ }^{1} D\right)+\mathrm{O}_{2} \rightarrow \\
\mathrm{O}\left({ }^{3} P\right)+\mathrm{O}_{2}\left({ }^{1} \Sigma\right) . \text { Steady state }\left(\mathrm{O}_{2}\left({ }^{1} \Sigma\right)\right) \\
\text { measured. } \\
\text { Noxon, } 1970(\mathrm{~b}) .\end{array}$ \\
\hline $4.5 \times 10^{-16}$ & $\begin{array}{l}\text { Flash photolysis of } \mathrm{O}_{2} \text { in vacuum uv. } \\
\text { Followed decay of }\left(\mathrm{O}_{2}\left({ }^{1}{ }^{2}\right)\right) \text {. } \\
\text { Filseth, et al., } 1970 \text { (d). }\end{array}$ \\
\hline$\sim 1 \times 10^{-15}$ & $\begin{array}{l}\text { Flow system. } \mathrm{O}_{2}\left({ }^{(1 \Sigma}\right) \text { produced by micro- } \\
\text { wave discharge in } \mathrm{O}_{2} \text {. Measured relaxa- } \\
\text { tion rate of }\left(\mathrm{O}_{2}\left({ }^{1} \Sigma\right)\right) \text {. } \\
\text { O'Brien, Myers, } 1970(\mathrm{e}) \text {. }\end{array}$ \\
\hline
\end{tabular}

$k_{1}$

(a)
Data-Continued

\begin{tabular}{|c|c|}
\hline & Data-Continued \\
\hline \multicolumn{2}{|c|}{$\begin{array}{l}\text { Units of } k \text { are } \mathrm{cm}^{3} \text { molecule } \mathrm{e}^{-1} \mathrm{~s}^{-1} \text {; all data at } 300 \mathrm{~K} ;\left(\mathrm{O}_{2}\left({ }^{1} \Sigma\right) \text { deter- }\right. \\
\text { mined from intensity of } 762 \mathrm{~nm} \text { emission }\left(\mathrm{b}^{1} \Sigma-X^{3} \Sigma\right)\end{array}$} \\
\hline$k_{1}\left(\mathrm{M}=\mathrm{N}_{2}\right)$ & Conditions \\
\hline $2.0 \pm 0.5 \times 10^{-15}$ & Noxon, 1970 (b). \\
\hline $1.8 \times 10^{-15}$ & Filseth, et al., 1970 (d). \\
\hline $3 \pm 1 \times 10^{-15}$ & O'Brien, Myers, 1970 (e). \\
\hline$k_{1}\left(\mathrm{~N}_{2}\right) / k_{1}\left(\mathrm{O}_{2}\right)=1.5$ & $\begin{array}{l}\text { Stopped flow reactor. Microwave discharge } \\
\text { in } \mathrm{O}_{2} \text {. Steady state }\left(\mathrm{O}_{2}\left({ }^{1} \mathrm{\Sigma}\right)\right) \text { measured. } \\
\text { Relative values of } k_{\mathrm{M}} \text { converted to abso- } \\
\text { lute values by adopting value of } k\left(\mathrm{M}=\mathrm{O}_{2}\right) \\
\text { in (b). }\end{array}$ \\
\hline 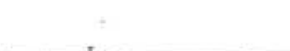 & Becker, et al., 1971 (g). \\
\hline$k_{1}\left(\mathrm{M}=\mathrm{H}_{2} \mathrm{O}\right)$ & . \\
\hline $3.3 \times 10^{-12}$ & Filseth, et al., 1970 (d). \\
\hline $4 \pm 0.6 \times 10^{-12}$ & O'Brien, Myers, 1970 (e). \\
\hline $5.5 \times 10^{-12}$ & $\begin{array}{l}\text { Same conditions as (d). } \\
\text { Stuhl, Niki, } 1970 \text { (f). }\end{array}$ \\
\hline $\begin{array}{l}k_{1}\left(\mathrm{H}_{2} \mathrm{O}\right) / k_{1}\left(\mathrm{O}_{2}\right) \\
=3.3 \pm 0.7) \times 10^{4}\end{array}$ & Becker, et al, 1971 (g). \\
\hline
\end{tabular}




\section{Preferred Values}

\begin{tabular}{l|l|c}
\hline \hline \multicolumn{1}{c|}{$\mathrm{M}$} & \multicolumn{1}{|c|}{$k_{M}$} & Estimated uncertainty \\
\hline $\mathrm{O}_{2}$ & $1.5 \times 10^{-16} \mathrm{~cm}^{3}$ molecule ${ }^{-1} \mathrm{~s}^{-1}$ & $\pm 33 \%$ \\
$\mathrm{~N}_{2}$ & $2.0 \times 10^{-15}$ & $\pm 25 \%$ \\
$\mathrm{H}_{2} \mathrm{O}$ & $4 \times 10^{-12}$ & $\pm 50 \%$ \\
\hline
\end{tabular}

\section{Remarks}

The values in (b) are adopted for $\mathrm{M}=\mathrm{N}_{2}$ and $\mathrm{O}_{2}$. The value for $\mathrm{H}_{2} \mathrm{O}$ is based on (d) and (f). The preferred values are supported by both the photolysis and flow type experiments. A.possible source of uncertainty in the value of $k_{1}\left(\mathrm{M}=\mathrm{O}_{2}\right)$ is the observed pressure effect on the quenching rate (d). Filseth, et al. (d) recommend the value
$4.5 \times 10^{-16}$ for $k\left(\mathrm{M}=\mathrm{O}_{2}\right)$. However stopped flow experiments ( $\mathrm{g}$ give the relative rate ratio for $\mathrm{O}_{2}$ and $\mathrm{N}_{2}$ the same as in (b). Earlier literature is discussed in (b) and (d).

\section{References}

(a) G. Herzberg, Spectra of Diatomic Molecules, D. Van Nostrand and Co., Princeton, NJ., 1950.

(b) J. F. Noxon, J. Chem. Phys., 52, 1852 (1970).

(c) F. Stuhl and K. H. Welge, Can. J. Chem., 47, 1870 (1969).

(d) S. V. Filseth, A. Zia, and K. H. Welge, J. Chem. Phys., 52, 5502 (1970).

(e) R.J. O'Brien, Jr., and G. H. Myers, J. Chem. Phys., 53, 3832 (1970).

(f) F. Stuhl and H. Niki, Chem. Phys. Letters, 7, 473 (1970).

(g) K. H. Becker, W. Groth, and U. Schurath, Chem. Phys. Letters, 8, 259 (1971).

J. T. Herron, R. E. Huie

December 1971

\subsection{Photolysis of Ozone in Red Light $(\lambda \sim 600 \mathrm{~nm})$}

$\mathrm{O}_{3}+h \nu \rightarrow \mathrm{O}\left({ }^{3} P\right)+\mathrm{O}_{2}\left(\mathrm{X}^{3} \Sigma_{\bar{g}}\right)$

which is followed by the reactions

$\mathrm{O}+\mathrm{O}_{2}+\mathrm{M} \rightarrow \mathrm{O}_{3}+\mathrm{M}$,

$k_{2}$

$\mathrm{O}+\mathrm{O}_{3} \rightarrow \mathrm{O}_{2}+\mathrm{O}_{2}$

Auxiliary Data

$\Delta H_{0}^{\circ}(1)=-\Delta H_{0}^{\circ}(2)=+101.4 \mathrm{~kJ} / \mathrm{mol}(=24.24 \mathrm{kcal} / \mathrm{mol})$

Thermodynamic threshold: $\lambda=1180 \mathrm{~nm}$.

$\Delta H_{0}^{\circ}(3)=-392.1 \mathrm{~kJ} / \mathrm{mol}(=-93.72 \mathrm{kcal} / \mathrm{mol})$

Absorption Spectrum 440-850 nm. (figure 1).

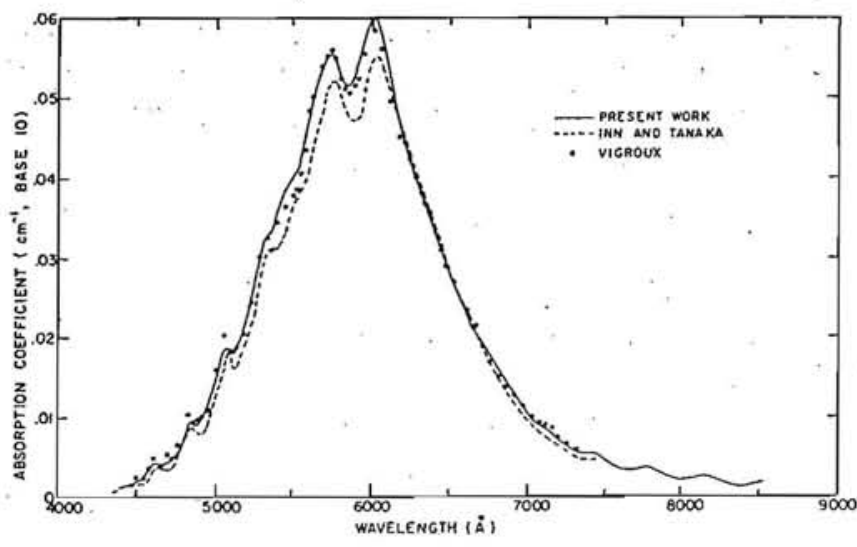

FIGURE 1. Absorption coefficient of ozone, 440-850 nm (Chappuis bands). Absorption coefficient in units of $\mathrm{cm}^{-1}$ (atm at $\left.273 \mathrm{~K}\right)^{-1}$ base 10 , i.e. $k=(1 / p \cdot l) \log _{10}\left(I_{0} / I\right)$. (Figure 4 from M. Griggs, J. Chem. Phys. 49, 857 (1968) with consent of the author.)

Hearn (e) measured the absorption coefficient at the $\mathrm{Hg}$ line, $\lambda=576.95 \mathrm{~nm}$, to be $0.0555 \pm 0.0010$. This agrees well with the solid trace in figure 1 . $k_{1}$

\begin{tabular}{|c|c|}
\hline & Data \\
\hline $\begin{array}{l}\text { Quantum Yield (overall) } \\
\text { maximum: } 2.0\end{array}$ & $\begin{array}{l}570<\lambda<630 \mathrm{~nm}, \text { steady } \\
\text { photolysis at } 5,18, \text { and } 25^{\circ} \mathrm{C} . \\
25<P\left(\mathrm{O}_{3}\right)<200 \text { torr. } \\
\mathrm{I}<P\left(\mathrm{O}_{2}\right)<250 \text { torr. } \\
\text { With and without added } \mathrm{He}, \mathrm{Ar} \text {, } \\
\mathrm{N}_{2}, \mathrm{CO}_{2} \Delta \text { press. vs. } \Delta t \\
\text { measured. } \\
\text { Castellano, Schumacher, } 1962 \text { (b). }\end{array}$ \\
\hline $\begin{array}{l}\text { Presence of excited ground } \\
\text { state } \mathrm{O}_{2}\end{array}$ & $\begin{array}{l}\lambda=595 \mathrm{~nm} \text {, flash photolysis } \\
{\left[\mathrm{O}_{2}^{*}\right] \text { vs. time meas. }} \\
\text { Ellis, McGarvey, McGrath, } 197 \mathrm{l} \text { (c). }\end{array}$ \\
\hline
\end{tabular}

Recommendation

Primary quantum yield, reaction $(1)=1.0$, for 580 $<\lambda<620 \mathrm{~nm}$. It probably is the same throughout the Chappuis band. Mechanism as given in the first section, above.

Expression for quantum yield (steady state in [O]), from (b) is

$$
\text { Q.Y. }=2 /\left(1+\left(k_{2}\left[\mathrm{O}_{2}\right] / k_{3}\left[\mathrm{O}_{3}\right]\right)[\mathrm{M}]\right),
$$

where

$$
[\mathrm{M}]=\left[\mathrm{O}_{3}\right]+\alpha_{\mathrm{O}_{2}}\left[\mathrm{O}_{2}\right]+\alpha_{\mathrm{X}}[\mathrm{X}],
$$

in which $\alpha_{\mathrm{X}}$ is the efficiency of molecule $\mathrm{X}$ relative to $\alpha_{0_{3}}=1$ in reaction (2).

For $\mathrm{O}_{2}, \mathrm{~N}_{2}, \mathrm{CO}_{2}, \mathrm{He}, \mathrm{Ar}, \alpha=0.44,0.39,0.96,0.34$, 0.25 at $291 \mathrm{~K} . \log _{10}\left[\left(k_{2} / k_{3}\right] / \mathrm{cm}^{3}\right.$ molecule $\left.{ }^{-1}\right]=(23.64 \pm$ $0.25)+1.506(1000 / T)$ for $200<T<1000 \mathrm{~K}$ (from ref. (f)).

\section{Comments}

Steady laboratory photolysis in the Chappuis bands is explainable on basis of the mechanism in the first sec- 
tion and q.y. expression in "Recommendation" above. The observed quantum yield is well fit by the expression for $0.01<\left[\mathrm{O}_{2}\right] /\left[\mathrm{O}_{3}\right]<40$. Extrapolation to higher ratios is expected to be good.

Although vibrationally excited ground state $\mathrm{O}_{2}$ has been observed, (c), with sufficient energy to decompose $\mathrm{O}_{3}$, no effect has been found in the photolysis. Presumably energy transfer is inefficient.

Although the process: $\mathrm{O}_{3}+h \nu \rightarrow \mathrm{O}_{2}\left({ }^{1} \Delta\right)+\mathrm{O}\left({ }^{3} P\right)$ has a thermodynamic threshold of $\lambda=611.0 \mathrm{~nm}$, no effect on the q.y. from the reaction of $\mathrm{O}_{2}\left({ }^{1} \Delta\right)$ with $\mathrm{O}_{3}$ has been observed. (In contrast, such an effect is postulated in the uv photolysis.) For this reason the primary process is given as in the first section above. If $\mathrm{O}_{2}\left({ }^{1} \Delta\right)$ were demonstrated to be a primary product from absorption in the Chappuis bands, the uv photolysis mechanisms would have to be reconsidered.

Ref. (b)

Absolute quantum yields determined by a difference method for many points in each run for up to 25 percent conversion. This means that the $\left[\mathrm{O}_{2}\right] /\left[\mathrm{O}_{3}\right]$ ratio varies sharply in each run. Data fit to the mechanism in
"Recommendation" (above) to obtain $k_{3} / k_{2}$. The mechanism reproduces the observed $\Phi$ 's to better than \pm 0.1 . The effect of $\mathrm{O}_{2}$ is to decrease the quantum yield, via reaction (2). Limit at high $\left[\mathrm{O}_{2}\right] /\left[\mathrm{O}_{3}\right]: \Phi$ tends to zero. Earlier studies showing higher q.y. discussed and refuted.

Ref. (c)

Presence of $\mathrm{O}_{2}\left(X^{3} \Sigma_{\bar{g}}, v>0\right)$ demonstrated with a vibrational distribution similar to that observed in uv photolysis, both during photolysis and as a slow process afterwards. Due to reaction (3).

\section{References}

(a) D. D. Wagman, et al, Nat. Bur. Stand. Tech. Note 270-3 (1968).

(b) E. Castellano and H. J. Schumacher, J. Chem. Phys. 36, 2238 (1962); Z. fur phys. Chem. N.F. 34, 198 (1962).

(c) D. M. Ellis, J. J. McGarvey, and W. D. McGrath, Nature Physical Science 229, 153 (1971).

(d) M. Griggs, J. Chem. Phys. 49, 857 (1968).

(e) A. G. Hearn, Proc. Phys. Soc. 78, 932 (1961).

(f) H. S. Johnston, Nat. Stand. Ref. Data Series-Nat. Bur. Stand. No. 20 (1968) Table 17 (essentially quoting ref. b), and Table 28.

David Garvin

March 1972

\subsection{Ultraviolet Photolysis of $\mathrm{O}_{3}$ : Quantum Yields}

Photolysis reactions of ozone pertinent to laboratory studies, $\lambda \leqq 334$ $\mathrm{nm}$, with their enthalpies of reaction

\begin{tabular}{c|r|r|r}
\hline \hline & \multicolumn{2}{|c|}{$\Delta H_{(28 s)}^{\circ}(\mathrm{a}, \mathrm{b})$} & \\
\cline { 2 - 3 } & $\mathrm{kJ} \mathrm{mol}{ }^{-1}$ & $\left(\mathrm{kcal} \mathrm{mol}^{-1}\right)$ & \\
\hline $\mathrm{O}_{3}+h \nu \rightarrow \mathrm{O}\left({ }^{1} D\right)+\mathrm{O}_{2}\left(X^{3} \Sigma_{g}^{-}\right)$ & 296.6 & $(70.9)$ & $1 \mathrm{a}$ \\
$O\left({ }^{1} D\right)+\mathrm{O}_{2}\left({ }^{1} \Delta\right)$ & 390.4 & $(93.3)$ & $1 \mathrm{~b}$ \\
$O\left({ }^{1} D\right)+\mathrm{O}_{2}\left({ }^{1} \Sigma_{g}^{+}\right)$ & 453.1 & $(108.3)$ & $1 \mathrm{c}$ \\
$O\left({ }^{3} P\right)+\mathrm{O}_{2}\left(X^{3} \Sigma_{g}^{-}\right)$ & 106.3 & $(25.4)$ & $1 \mathrm{~d}$ \\
$O\left({ }^{3} P\right)+\mathrm{O}_{2}\left({ }^{1} \Delta\right)$ & 200.8 & $(48.0)$ & $1 \mathrm{e}$ \\
$O\left({ }^{3} P\right)+\mathrm{O}_{2}\left({ }^{1} \Sigma_{g}^{+}\right)$ & 263.6 & $(63.0)$ & If \\
\hline
\end{tabular}

Secondary reactions considered in laboratory studies of ozone photolysis

\begin{tabular}{|c|c|c|c|}
\hline $\mathrm{O}_{2}\left({ }^{1} \Delta\right)+\mathrm{O}_{3} \rightarrow \mathrm{O}\left({ }^{3} P\right)+2 \mathrm{O}_{2}$ & 12.6 & $(3.0)$ & $2 \mathrm{a}$ \\
\hline $\mathrm{O}_{2}\left({ }^{1} \Delta\right)+\mathrm{M} \rightarrow \mathrm{O}_{2}+\mathrm{M}$ & -94.3 & $(-22.5)$ & $2 b$ \\
\hline $\mathrm{O}\left({ }^{1} D\right)+\mathrm{O}_{3} \rightarrow \mathrm{O}_{2}^{*}+\mathrm{O}_{2}$ & -581.6 & $(-139.0)$ & $3 a$ \\
\hline $\begin{aligned} & \rightarrow 2 \mathrm{O}\left({ }^{3} P\right)+\mathrm{O}_{2} \\
\mathrm{O}_{2}^{*}+\mathrm{O}_{3} \rightarrow & \mathrm{O}\left({ }^{3} P\right)+2 \mathrm{O}_{2}\end{aligned}$ & $\begin{array}{r}-83.3 \\
106.3\end{array}$ & $\begin{array}{r}(-19.9) \\
(25.4)\end{array}$ & $\begin{array}{l}3 \mathrm{~b} \\
4 \mathrm{a}\end{array}$ \\
\hline$\rightarrow \mathrm{O}\left({ }^{1} D\right)+2 \mathrm{O}_{2}$ & 296.2 & $(70.8)$ & $4 b$ \\
\hline $\mathrm{O}\left({ }^{1} D\right)+\mathrm{M} \rightarrow \mathrm{O}\left({ }^{3} P\right)+\mathrm{M}$ & -189.8 & $(-45.4)$ & 5 \\
\hline $\mathrm{O}\left({ }^{1} D\right)+\mathrm{O}_{2} \rightarrow \mathrm{O}\left({ }^{3} P\right)+\mathrm{O}_{2}\left({ }^{1} \Sigma_{g}^{+}\right)$ & -32.8 & $(-7.8)$ & $6 a$ \\
\hline$\rightarrow \mathrm{O}\left({ }^{3} P\right)+\mathrm{O}_{2}$ & -189.8 & $(-45.4)$ & $6 \mathrm{~b}$ \\
\hline $\mathrm{O}_{2}\left({ }^{1} \Sigma_{g}^{+}\right)+\mathrm{O}_{3} \rightarrow \mathrm{O}\left({ }^{3} P\right)+2 \mathrm{O}_{2}$ & -50.2 & $(-12.0)$ & $7 \mathrm{a}$ \\
\hline $\mathrm{O}_{2}\left({ }^{1} \Sigma_{g}^{+}\right)+\mathrm{M} \rightarrow \mathrm{O}_{2}+\mathrm{M}$ & -156.9 & $(-37.5)$ & $7 \mathrm{~b}$ \\
\hline $\mathrm{O}\left({ }^{3} P\right)+\mathrm{O}_{3} \rightarrow \mathrm{O}_{2}^{* *}+\mathrm{O}_{2}$ & -391.6 & $(-93.6)$ & 8 \\
\hline $\mathrm{O}\left({ }^{3} P\right)+\mathrm{O}_{2}+\mathrm{M} \rightarrow \mathrm{O}_{3}+\mathrm{M}$ & -106.3 & $(-25.4)$ & 9 \\
\hline
\end{tabular}

Notes: Enthalpies for reactions $3 \mathrm{a}, 4 \mathrm{a}$, and 8 are calculated using $\Delta H_{f}=0$ for $\mathrm{O}_{2}^{*}$ and $\mathrm{O}_{2}^{* *}$. When an electronic state designation is not shown, the ground state is implied.
Auxiliary Data

Threshold wavelengths, at $0 \mathrm{~K}$ for reactions la-f, in $\mathrm{nm}$ (c)

\begin{tabular}{c|c|c|c}
\hline \hline $\mathrm{O}_{2}:$ & $X^{3} \Sigma_{g}^{-}$ & ${ }^{1} \Delta_{g}$ & ${ }^{1} \Sigma_{g}^{+}$ \\
\hline$O:{ }^{3 P}$ & 1180 & 611 & 463 \\
${ }^{1} D$ & 411 & 310 & 266 \\
\hline
\end{tabular}

Enthalpies of formation of species $(a, b)$

\begin{tabular}{|c|c|c|c|c|}
\hline & \multicolumn{2}{|c|}{$\Delta H_{0}^{\circ}$} & \multicolumn{2}{|c|}{$\Delta H_{298}^{\circ}$} \\
\hline & $\mathrm{kJ} \mathrm{mol-1}^{-1}$ & $\left(\mathrm{kcal} \mathrm{mol}^{-1}\right)$ & $\mathrm{kJ} \mathrm{mol}^{-1}$ & $\left(\mathrm{kcal} \mathrm{mol}^{-1}\right)$ \\
\hline $\mathrm{O}_{2}: X^{3} \Sigma_{g}^{-}$ & 0.0 & $(0.0)$ & 0.0 & $(0.0)$ \\
\hline${ }^{1} \Delta$ & 94.30 & $(22.54)$ & 94.30 & (22.54) \\
\hline$' \Sigma_{g}^{+}$ & 156.9 & (37.51) & 156.9 & $(37.51)$ \\
\hline $0:{ }^{3 P}$ & 246.8 & (58.98) & 249.2 & (59.55) \\
\hline${ }^{1} D$ & 436.5 & (104.34) & 438.94 & (104.91) \\
\hline
\end{tabular}


Absorption Spectra and Coefficients

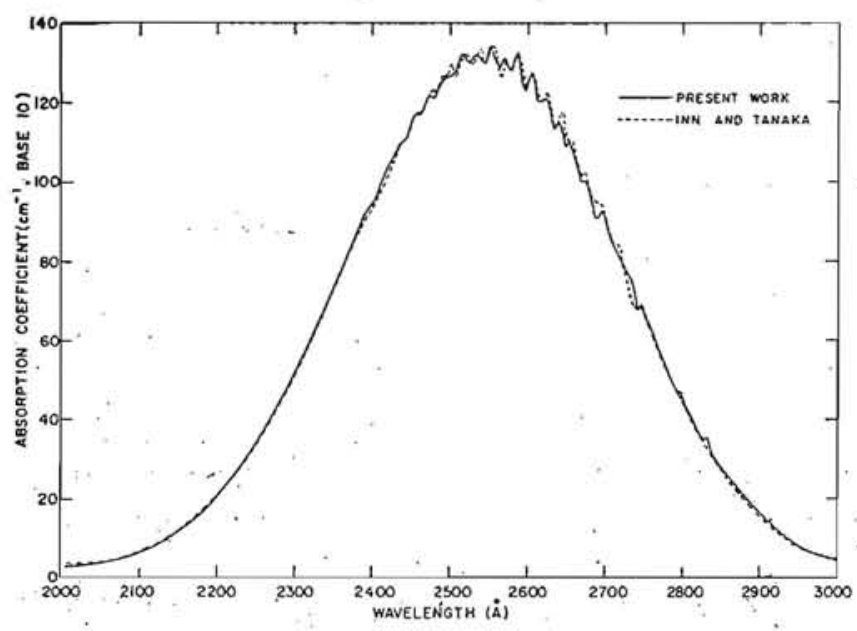

FIGURE 1. Absorption coefficient of ozone, 200-300 nm (Hartley band). $k$ in $\mathrm{cm}^{-1}$ (atm at $\left.273 \mathrm{~K}\right)^{-1}$ base 10. (Figure 2 from M. Griggs, J. Chem. Phys. 49, 857 (1968), reprinted with consent of the author.)

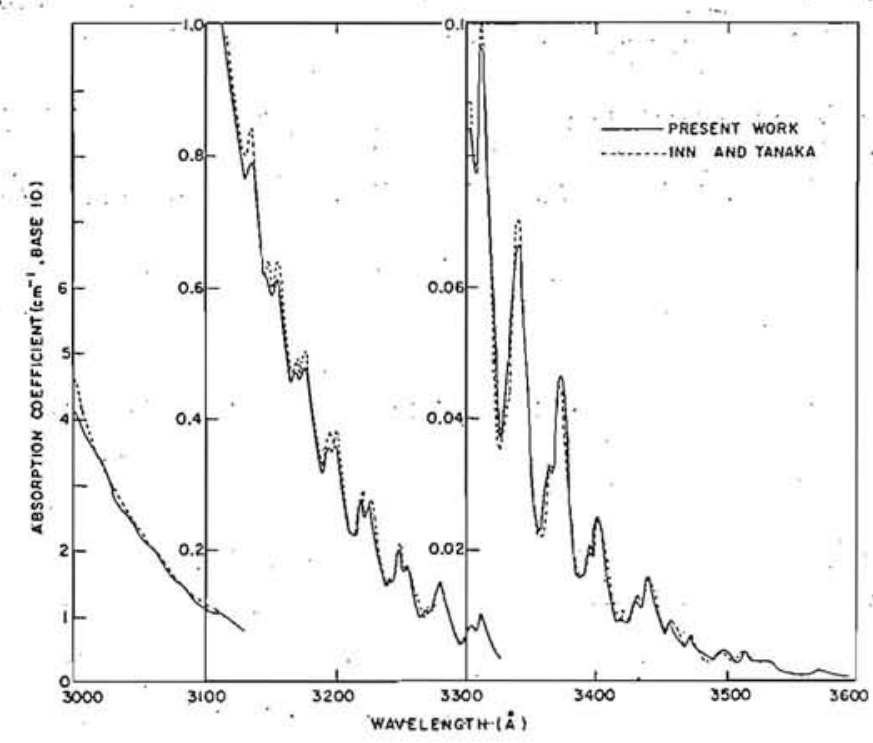

Figure 2. Absorption coefficient of ozone, 300-360 nm (Huggins band), $k$ in $\mathrm{cm}^{-1}$ (atm at $273 \mathrm{~K}$ ) ${ }^{-1}$ base 10 . (Figure 3 from M. Griggs, J. Chem. Phys. 49, 857 (1968), reprinted with consent of the author.)

Absorption Coefficients at $\mathrm{Hg}$ lines (d)

\begin{tabular}{c|c}
\hline$\lambda(\mathrm{nm})$ & $\begin{array}{c}\text { Absorption coefficient } \\
\mathrm{cm}^{-1}(\mathrm{~atm} \text { at } 273)^{-1} \\
\text { base } 10\end{array}$ \\
\hline 253.65 & $133.9 \pm 1.9$ \\
289.36 & $17.2 \pm 0.3$ \\
296.73 & $6.969 \pm 0.030$ \\
302.15 & $3.340 \pm 0.014$ \\
334.15 & $0.0498 \pm 0.0007$ \\
& \\
\hline
\end{tabular}

These values measured by Hearn agree well with the traces marked "Inn and Tanaka" in figures 1 and 2.
Photochemical Data

Spectroscopic Evidence for Photolytic Formation of $\mathrm{O}\left({ }^{1} \mathrm{D}\right), \lambda<300 \mathrm{~nm}$.

Time rate of decay of $\mathrm{O}\left({ }^{1} D\right)$ emission immediately following flash photolysis (f). Quenching of emission by $\mathrm{N}_{2}$ in flash (f) and steady photolysis (e), due to reaction (5). Appearance and growth of emission from $\mathrm{O}_{2}\left({ }^{1} \Sigma_{g}^{+}\right)$ with addition of $\mathrm{O}_{2}$ to systems (e,f), due to reaction 6 a.

\begin{tabular}{l|l}
\hline \hline$\phi\left(O\left({ }^{1} D\right)\right) \sim 1$ & $\lambda=254$ nm steady. \\
& Gauthier, Snelling, 1971 (e). \\
$\phi\left(O\left({ }^{1} D\right)\right) / \phi\left(\mathrm{O}_{2}\left({ }^{1} \Sigma_{g}^{+}\right)\right)$ & $\lambda=254$ nm flash. \\
$\geq 20$ & Gilpin, Schiff, Welge, 1971 (f). \\
\hline
\end{tabular}

Chemical Evidence on Photolytic Formation of $\mathrm{O}\left({ }^{1} \mathrm{D}\right)$ as a Function of Wavelength

Liquid phase steady photolysis of $\mathrm{O}_{3}$ in $\mathrm{Ar}$, at $87 \mathrm{~K}(\mathrm{~g})$, and in $\mathrm{N}_{2}$; at $95 \mathrm{~K}(\mathrm{~h})$. Measurement of quantum yields for ozone disappearance, atom exchange (total atom production) and $\mathrm{N}_{2} \mathrm{O}$ formation. These show sharp drops in $\Phi\left(\mathrm{O}_{3}\right)$ and $\Phi\left(\mathrm{N}_{2} \mathrm{O}\right)$ at $\lambda>300 \mathrm{~nm}$, but no change in $\Phi$ (exchange). Higher $\Phi$ 's for $\lambda<300 \mathrm{~nm}$ are attributed to $\mathrm{O}\left({ }^{1} D\right)$, assuming that excited molecules are quenched by the solvent and that $\mathrm{O}\left({ }^{3} \mathrm{P}\right)$ $+\mathrm{O}_{3} \rightarrow 2 \mathrm{O}_{2}$ does not occur at these temperatures. See also section on total gas phase quantum yields.

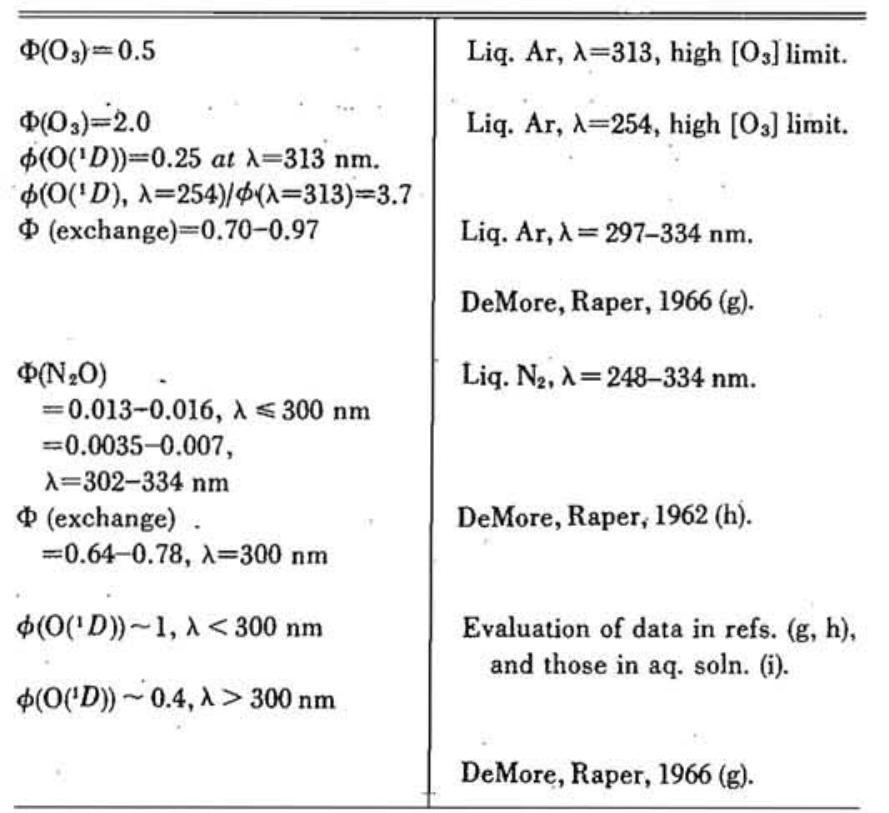

Spectroscopic Evidence for the Photolytic formation of $\mathrm{O}_{2}\left({ }^{1} \Delta\right)$

Steady photolysis of $\mathrm{O}_{3}, \lambda=254 \mathrm{~nm}$, and measurement of the emission from $\mathrm{O}_{2}\left({ }^{1} \Delta\right), \lambda=1270 \mathrm{~nm}$. Two studies $(e, j)$ show the emission to be proportional to $\left[\mathrm{O}_{3}\right]$. It is independent of added $\mathrm{O}_{2}$ and $\mathrm{N}_{2}$ (e). This indicates that $\mathrm{O}\left({ }^{1} D\right)$ is not a precursor, as for example in reac- 
tions (3) and (6). The studies suggest that $\phi\left(\mathrm{O}_{2}^{1} \Delta\right)$ is close to unity. For other evidence of the presence of $\mathrm{O}_{2}\left({ }^{1} \Delta\right)$ in ozone photolysis see $(\mathrm{hh}, \mathrm{ii})$.

Total Quantum Yields, Gas Phase Photolysis of $\mathrm{O}_{3}$ at high $\mathrm{O}_{3} / \mathrm{O}_{2}$ Ratios

Absolute quantum yields for ozone decomposition in steady photolysis experiments, at various wavelengths, measured as a function of $\left[\mathrm{O}_{3}\right]$. Two distinct sets of experiments, show sharply different results. In one $(\mathrm{k}, \mathrm{l}, \mathrm{ff}), \Phi\left(\mathrm{O}_{3}\right)=6, \lambda<310 \mathrm{~nm}$ independent of $\left[\mathrm{O}_{3}\right]$ and $\phi=4, \lambda=334 \mathrm{~nm}$. In the other (c, m, n), $\Phi$ is $\sim 4$ at low $\left[\mathrm{O}_{3}\right]$ and increases with $\left[\mathrm{O}_{3}\right]$ for $\lambda<300 \mathrm{~nm}$. This increase in $\Phi$ is proportional to the surface/volume ratio of the photolysis cell. In both sets added $\mathrm{N}_{2}$ and $\mathrm{O}_{2}$ reduced the quantum yield in a manner consistent with other experiments, $\lambda<310 \mathrm{~nm}$. However $\mathrm{N}_{2}$ had no effect at $\lambda=334 \mathrm{~nm}$ (ff). Both sets used filtered $\mathrm{Hg}$ light sources, and similar actinometry.

\begin{tabular}{|c|c|}
\hline$\Phi\left(\mathrm{O}_{3}\right)$ & System \\
\hline$\cdot$ & $\begin{array}{l}\text { Steady photolysis, } \lambda=254 \mathrm{~nm} \text {. } \\
\quad 10<\left[\mathrm{O}_{3}\right]<100 \text { torr. } \\
\text { Ellenrieder, Castellano, Schumacher, } 1971 \\
\text { (k). }\end{array}$ \\
\hline 6 (initial value) & $\begin{array}{l}\text { Steady photolysis, } \lambda=308 \pm 24 \mathrm{~nm} \text {. } \\
\quad 15<\left[\mathrm{O}_{3}\right]<300 \text { torr. } \\
\text { Castellano, Schumacher, } 1969 \text { (1). }\end{array}$ \\
\hline $\begin{array}{l}\sim 4+\mathrm{a}\left[\mathrm{O}_{3}\right] \\
\quad \mathrm{a}(297) \sim \mathrm{a}(254) \\
\mathrm{a}(313) / \mathrm{a}(297) \sim 0 .]\end{array}$ & $\begin{array}{l}\text { Steady photolysis, } \lambda=248,254 \\
289 / 292,297 / 302,313,334 \mathrm{~nm} \\
10<\left[\mathrm{O}_{3}\right]<50 \text { torr. }\end{array}$ \\
\hline & Jones, Wayne, 1970 (c). \\
\hline$\sim 4+\mathrm{a}\left[\mathrm{O}_{3}\right]$ & $\begin{array}{l}\text { Steady photolysis, } \lambda=254 \mathrm{~nm} . \\
\quad 2<\left[\mathrm{O}_{3}\right]<50 \text { torr. } \\
\text { Norrish, Wayne, } 1965(\mathrm{~m})\end{array}$ \\
\hline$\sim 4$ & $\begin{array}{l}\text { Steady photolysis, } \lambda=254 \mathrm{~nm} \text {, flow system. } \\
\quad 5 \times 10^{-2}<\left[\mathrm{O}_{3}\right]<2 \text { torr. } \\
\text { Jones, Kaczmar, Wayne, } 1970 \text { (n). }\end{array}$ \\
\hline 4 (initial value) & $\begin{array}{l}\text { Steady photolysis, } \lambda=334 \mathrm{~nm} .50<P\left(\mathrm{O}_{3}\right) \\
\quad<300 \text { torr, } P\left(\mathrm{O}_{2}\right), P\left(\mathrm{~N}_{2}\right) \text { to } 500 \text { torr. } \\
\quad \Delta \text { Press } / \Delta t \text { meas. } \\
\text { Castellano, Schumacher, } 1972 \text { (ff). }\end{array}$ \\
\hline 4.7 & $\begin{array}{l}\text { Deduced from "intermediate" q.y. } \lambda=254 \\
\text { nm and study of } \mathrm{O}\left({ }^{1} \mathrm{D}\right) \text { reactions. }\left[\mathrm{O}_{3}\right] \\
<10^{-6} \text { moT dm }{ }^{-3} \text {. } \\
\text { Giachardi, Wayne, } 1972(\mathrm{gg}) \text {. }\end{array}$ \\
\hline
\end{tabular}

Effect of Non-Reactive Gases on the Photolysis of $\mathrm{O}_{3}$

Inert gases have several effects. First they reduce the total quantum yield. $\Delta \Phi\left(\mathrm{O}_{3}\right) \sim 2$ for high enough pressures $(\mathrm{k}, \mathrm{l}, \mathrm{o}, \mathrm{p}, \mathrm{s})$. The efficiency varies considerably with the identity of the added gas $(1, \mathrm{p}, \mathrm{q})$. This effect, due to reaction with $\mathrm{O}\left({ }^{1} D\right)$, has been observed only below $\lambda=310 \mathrm{~nm}$. At the same time they quench emission from $\mathrm{O}\left({ }^{1} D\right)$ (e, f). This effect is attributed to reaction (5). The reactions with $\mathrm{N}_{2}$ and $\mathrm{CO}_{2}$ are the most effective. In flash photolysis experiments added $\mathrm{N}_{2}$ changes markedly the concentration-time pattern immediately after the flash (q). In the gas phase only traces of $\mathrm{N}_{2} \mathrm{O}$ are formed (m). Rate ratios, $k_{5} / k_{3}$, are reported in references $(e, k, l, r)$.

Second, they reduce the quantum yield via the three body reaction (9). This effect is the same, quantitatively, as in the photolysis of $\mathrm{O}_{3}$ in red light $(\mathrm{l}, \mathrm{t})$.

Third they quench $\mathrm{O}_{2}\left({ }^{1} \Delta\right)$, reaction $(2 \mathrm{~b})$, and $\mathrm{O}_{2}\left({ }^{1} \Sigma_{g}^{+}\right)$, reaction (7b). These are slow reactions that are relatively unimportant in the steady state photolysis of high concentration ozone and which occur at long times after flash photolysis.

\section{Effect of Added $\mathrm{O}_{2}$ on the Photolysis of $\mathrm{O}_{3}$}

Molecular oxygen has two important effects. First it quenches emission from $O\left({ }^{1} D\right)$ and, at the same time, produces emission from $\mathrm{O}_{2}\left({ }^{1} \Sigma_{g}^{+}\right)(\mathrm{e}, \mathrm{f})$. This is due to reaction (6a). Because (7b) is slow, this changes the concentration-time pattern after flash photolysis $(q)$ without affecting the quantum yield (reaction (6a) followed by (7a)). Rate ratios, $k_{6} / k_{3}$, are reported in references $(e, f, k, l)$.

Second, it reduces the quantum yield principally by reformation of $\mathrm{O}_{3}$ in reaction (9), but also via quenching of $\mathrm{O}\left({ }^{1} D\right)$, reaction $(6 \mathrm{~b})(\mathrm{k}, \mathrm{l}, \mathrm{m})$.

\section{Vibrationally Excited Molecular Oxygen}

Absorption from ground state molecular oxygen in vibrational levels up to $v=30$ has been observed following flash photolysis of ozone. (o, s, u, v, x, y). Attributed to products of reactions (3) and (8). In one study (y) using a monochromatic flash source at $\lambda$ $=595 \mathrm{~nm}$, excited ground state $\mathrm{O}_{2}$ was observed. At this wavelength only reaction (8) can occur. To date, there is no clear, quantitative evidence that these excited molecules affect the quantum yield for $\mathrm{O}_{3}$ photolysis.

\section{Effect of Reactive Molecules-Impurities}

The principal impurities expected in high concentration $\mathrm{O}_{3}$ are $\mathrm{H}_{2} \mathrm{O}, \mathrm{N}_{2} \mathrm{O}_{5}, \mathrm{CO}_{2}$, and hydrocarbons. These either are present in the $\mathrm{O}_{2}$ from which the $\mathrm{O}_{3}$ is made or are produced in the electric discharge of the ozonizer. They may be concentrated along with the $\mathrm{O}_{3}$.

Photolysis of $\mathrm{O}_{3}$ in the presence of $\mathrm{H}_{2}$ and $\mathrm{H}_{2} \mathrm{O}$ and other hydrogen containing molecules shows formation of $\mathrm{OH}$ and a $\Phi$ indicating a chain reaction $(\mathrm{c}, \mathrm{z}, \mathrm{aa}, \mathrm{bb})$. An increased $\Phi$ also occurs with $\mathrm{CO}_{2}$ (cc). Nitrogen dioxide (rapidly converted to $\mathrm{N}_{2} \mathrm{O}_{5}$ ) is reported (m) to have only a small effect on the photolytic yields in high concentration $\mathrm{O}_{3}$ but at the same time introduces an important "dark reaction." This is undoubtedly the $\mathrm{N}_{2} \mathrm{O}_{5}$ catalyzed decomposition of $\mathrm{O}_{3}(\mathrm{dd})$. 


\section{Preferred Values}

Quantum yields for primary processes.

These are arbitrary, rounded values.

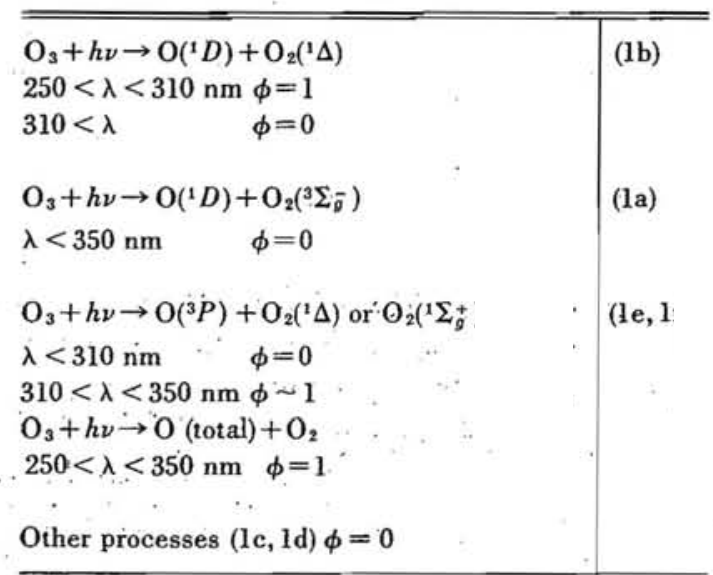

Remarks

Only the quantum yield is assessed here. uv photolysis of $\mathrm{O}_{3}$ is complex. It provides information on and is explained in terms of an extensive mechanism of secondary reactions. See reference (ee) for a recent review.

The preferred quantum yields are quite arbitrary. They are step functions (although there must be some wavelength region in which there is a gradual transition) because the data cannot support anything else. More studies of $\phi$ as a function of $\lambda 290-330 \mathrm{~nm}$ are badly needed.

\section{Photolysis Below $310 \mathrm{~nm}$}

The photolytic products at $\lambda=254 \mathrm{~nm}$ are $O\left({ }^{1} D\right)$ and $\mathrm{O}_{2}\left({ }^{1} \Delta\right)$. There is no evidence for $\mathrm{O}_{2}\left({ }^{1} \Sigma_{g}^{+}\right)$as a primary product, although the threshold for reaction (lc) is at $\lambda=266 \mathrm{~nm}$.

Schumacher's experiments $(k, l)$ show the same total quantum yield at $\lambda=254, \sim 313 \mathrm{~nm}$. DeMore's $(\mathrm{h}, \mathrm{g})$ show a change in quantum yield at $\lambda=300 \mathrm{~nm}$. Wayne's show a change between $\lambda=297 / 302$ and $313 \mathrm{~nm}$, as evidenced by the decreased "chain reaction" contribution. (c).

These are combined to indicate that reaction $(\mathrm{lb})$ is effective at all $\lambda$ shorter than its threshold.

This choice for the q.y. of (b) has two assumptions behind it: (1) that the break in q.y. in DeMore's experiments at $\lambda=300 \mathrm{~nm}$ (as opposed to $\lambda=310 \mathrm{~nm}$ ) is due to solvent effects, and (2) that wavelengths above $\lambda=305 \mathrm{~nm}$ (particularly $\lambda=313 \mathrm{~nm}$ ) are effective in Schumacher's even though the absorption coefficient is changing rapidly. If either of these assumptions is incorrect, $\phi$ for reaction (lb) will start to drop at about $\lambda=300 \mathrm{~nm}$.

There is no evidence concerning $\phi$ for $\lambda<248 \mathrm{~nm}$. Presumably it remains unity throughout the rest of the Hartley bands.

\section{Photolysis Above $310 \mathrm{~nm}$}

Two processes are assumed to occur (la) and either (le) or possibly (lf) subject to these constraints:

(1) The total atom production is the same above and below $\lambda=310 \mathrm{~nm}$. This means that quenching of $\mathrm{O}_{3}^{*}$ is unimportant.

(2) A quantum yield of 3-4 has been observed at $\lambda=$ $313,334 \mathrm{~nm}$ (c). This means that one product of photolysis must be excited. It may be either $\mathrm{O}$ or $\mathrm{O}_{2}$.

DeMore's estimate $(\mathrm{g})$ for $\phi\left({ }^{1} D\right)$ is an upper bound. This quantum yield decreases slowly with increasing $\lambda$ (above $310 \mathrm{~nm}$ ). The recent gas phase measurements at $\lambda=334 \mathrm{~nm}$ (ff) show no effect of $\mathrm{N}_{2}$ on $\Phi$. This indicates that $O\left({ }^{1} D\right)$ is absent. Therefore the preferred value for $O\left({ }^{1} D\right)$ production is given as 0 for $\lambda>310 \mathrm{~nm}$.

\section{Total Quantum Yields}

No recommendation is made for expressions relating the total quantum yield to the composition of a system containing $\mathrm{O}_{3}, \mathrm{O}_{2}$, and inert gas. We prefer the results in ref. $(\mathrm{k}, \mathrm{l})$ to those in (c). This preference rests solely on suspicion that the evidence for a chain reaction in (c) may be faulty. (See ref. (f) for data on reactions in the chain: (3a) and (4b).) However, we can offer no reasonable alternative interpretation.

The discrepancies can be resolved only by new experiments. It would be important in them to use monochromatic light sources, measure the absorption coeffcient, analyze the gas samples for impurities, stir the gases in optically thick systems, and report in detail on "dark" reactions.

Ref. $(k, l)$

The papers in Z. fur Phys. Chem. vol. 76 treat the 313 and $254 \mathrm{~nm}$ data according to the same mechanism and revise earlier numerical values and correct equations. This mechanism is $1 b, 2 a, 3 a, 4 a, 5,6 a, 6 b, 7 a, 8,9$. The experiments measure $\left(k_{6 a}+k_{6 b}\right) / k_{3 a}$ and $k_{5} / k_{3 a}$. They use values for $k_{9} / k_{8}$ from red light photolysis (ref. $t$ ). The deactivation rate ratios measured are sensitive functions of $k_{9} / k_{8}$. Using values from (w) for $k_{9} / k_{8}, k_{6} / k_{3 a} \sim 0.15$ as opposed to 0.23 . The expressions for $\Phi$ should not be used far outside the $[\mathrm{M}] /\left[\mathrm{O}_{3}\right]$ used in the studies. At higher values deactivation reactions such as (2b) and (7b) must enter. They would raise $\Phi$. Since similar results were obtained at $\lambda=254$ and $313 \mathrm{~nm}$, the fact that the system at $254 \mathrm{~nm}$ was optically thick probably is unimportant.

Ref. $(c, m, n)$

That this work shows a dependence of $\Phi$ on $\left[\mathrm{O}_{3}\right]$ suggesting a chain reaction $(3 \mathrm{a}, 4 \mathrm{~b})$ and wall deactivation of $O\left({ }^{1} D\right)$ leads one to suspect impurities. They could be concentrated when the $\mathrm{O}_{3}$ is condensed or absorbed on silica gel. However, a variety of preparative 
methods, analytical techniques, and actinometry were used, making this impurity thesis improbable. The presence of $\mathrm{NO}_{2}(\mathrm{~m})$ has only a slight effect (as it should by any mechanism). Water, if present, would be there at about 2 torr, which is unreasonably high (calculated from data in ref. (z)).

Ref. (cc)

The quantum yields in the presence of high pressures of $\mathrm{N}_{2}$ are, in 3 cases, of the same order of magnitude as those calculable from the expressions for $\Phi$ in refs. $(\mathrm{k}, \mathrm{l})$. One run without added $\mathrm{O}_{2}$, however, gives a $\Phi$ much smaller than it should from the same calculation. The authors feel that little weight should be given to these $\Phi$.

\section{Acknowledgement}

We wish to thank Drs. DeMore, Schumacher, Wayne, and Bair for their assistance. They have supplied additional information and data, answered questions, and made suggestions about the various experiments and this analysis.

\section{References}

(a) D. D. Wagman, 'et al., NBS Technical Note 270-3 (Jan. 1968).

(b) C. E. Moore, NBS Circular 467, Vol. 1 (1949).

(c) I. T. N. Jones and R. P. Wayne, Proc. Roy. Soc. A319, 273 (1970).

(d) W. Griggs, J. Chem. Phys. 49, 857 (1968), A. G. Hearn, Proc. Phys. Soc. 78, 932 (1961).

(e) M. Gauthier and D. R. Snelling, J. Chem. Phys. 54, 4317 (1971), Chem. Phys. Letters 5, 93 (1970).

(f) R. Gilpin, H. I. Schiff, and K. H. Welge, J. Chem. Phys. 55, 1087 (1971).

(g) W. B. DeMore and O. F. Raper, J. Chem. Phys. 44, 1780 (1966).

(h) W. B. DeMore and O. F. Raper, J. Chem. Phys. 37, 2048 (1962).

(i) H. Taube, Trans. Faraday Soc. 53, 656 (1957).

(j) I. T. N. Jones and R. P. Wayne, Proc. Roy. Soc. A32 1, 409 (1971).

(k) G. von Ellenrieder, E. Castellano, and H. J. Schumacher, Chem. Phys. Letters 9, 152 (1971), Z. fur Phys. Chem. Neue Folge 76,240 (1971).

(I) E. Castellano and H. J. Schumacher, Z. fur Phys. Chem. Neue Folge 65, 62 (1969), Z. fur Phys. Chem. Neue Folge 76, 258 (1971). (m) R. G. W. Norrish and R. P. Wayne, Proc. Roy. Soc. A288, 200 (1965).

(n) I. T. N. Jones, U. B. Kaczmar, and R. P. Wayne, Proc. Roy. Soc. A316, 431 (1970).

(o) V. D. Baiamonte, L. G. Hartshorn, and E. J. Bair, J. Chem. Phys. 55,3617 (1971).

(p) H. Webster and E. J. Bair, J. Chem. Phys. 53, 4532 (1970).

(q) D. Biedenkapp and E. J. Bair, J. Chem. Phys. 52, 6119 (1970).

(r) D. R. Snelling and E. J. Bair, J. Chem. Phys. 47, 228 (I967).

(s) D. R. Snelling, V. D. Baiamonte, and E. J. Bair, J. Chem. Phys. 44, 4137 (1966).

(t) E. Castellano and H. J. Schumacher, Z. Phys. Chemie Neue Folge 34, 198 (1962).

(u) W. D. McGrath and R. G. W. Norrish, Proc. Roy. Soc. A242, 265 (1957), A254, 317 (1960).

(v) R. V. Fitzsimmons and E. J. Bair, J. Chem. Phys. 40, 451 (1964).

(w) H. S. Johnston, Nat. Stand. Ref. Data Series-Nat. Bur. Stand. 20 (1968).

(x) V. D. Baiamonte, D. R. Snelling, and E. J. Bair, J. Chem. Phys. 44, 673 (1966).

(y) D. M. Ellis, J. J. McGarvey, and W. D. McGrath, Nature Phys. Sci. 229, 153 (1971).

(z) R. G. W. Norrish and R. P. Wayne, Proc. Roy. Soc. A288, 361 (1965).

(aa) L. J. Heidt and G. S. Forbes, J. Am. Chem. Soc. 56, 1617, 2365 (1934).

(bb) D. Katakis, J. Chem. Phys. 47,54l (1967).

(cc) W. B. DeMore and C. Dede, J. Phys. Chem. 74, 2621 (1970).

(dd) Discussed in S. W. Benson, The Foundation of Chemical Kinetics (McGraw-Hill Book Co., 1960), p 417, and in H. S. Johnston, Gas Phase Reaction Rate Theory (Ronald Press 1966) Chapter I, especially Tables 1-1, 1-2 and pages 30-32.

(ee) K. F. Preston and R. J. Cvetanovic, Decomposition of Inorganic Oxides and Sulfides, in Comprehensive Chemical Kinetics, ed. C. H. Bamford and C. F. H. Tipper (Elsevier Publishing Co., 1972) volume 4, pages $47-141$.

(fi) E. Castellano and H. J. Schumacher, Chem. Phys. Lett. 13, 625 (1972).

(gg) D. J. Giachardi and R. P. Wayne, Proc. Roy. Soc. A330, 131 (1972).

(hh) R. J. Donovan, L. J. Kirsch, and D. Husain, Chem. Phys. Lett. 7, 453 (1970).

(ii) R. E. Huffman, J. C. Larrabee, and V. C. Baisley, J. Chem. Phys. 50, 4594 (1969).

D. Garvin

July 1972

\section{Notes Added in Proof}

Additional measurements have been reported or brought to our attention since the preparation of these data sheets. The following notes summarize these points. Where a recommendation has been changed, the revised value is incorporated in the summary table and in the data sheets, but no attempt has been made to discuss these new data in the body of the text.

\section{Section 4.5. The Reaction Between $\mathrm{H}_{\text {and }} \mathrm{NO}_{2}$}

The activation energy that results from combining the room temperature value of $k_{1}$ by Phillips and Schiff (b) with the $633 \mathrm{~K}$ data of Ashmore and Tyler (d) is changed from 2.0 to $1.5 \mathrm{kcal} / \mathrm{mol}$ when one uses the newer recommendation of $3 \times 10^{-32} \mathrm{~cm}^{6}$ molecule ${ }^{-2} \mathrm{~s}^{-1}$ for $k(\mathrm{H}+$ $\left.\mathrm{O}_{2}+\mathrm{H}_{2}\right)$ at $633 \mathrm{~K} . *$ This improves the agreement with the value of the activation energy resulting from combining the room temperature results (b) with the 500$540 \mathrm{~K}$ data in (c). Using $E=1.5 \mathrm{kcal} / \mathrm{mol}$, then $k(220) /$ $k(300) \sim 0.4$.

\footnotetext{
•D. L. Baulcb, D. D. Drysdale, D. G. Horne, A. C. Lloyd, Evaluated Kinetic Data for High Temperature Reactions volume 1 , Homogenous gas phase reactions of the $\mathrm{K}_{2} \mathrm{O}_{2}$ systems. Butterworth \& Co., London (1972).
} 
Section 4.18. The Reaction between $\mathrm{H}_{2} \mathrm{O}$ and $\mathrm{O}\left({ }^{1} \mathrm{D}\right)$

and

\section{Section 4.23. The Reaction between $\mathrm{N}_{2} \mathrm{O}$ and $\mathrm{O}\left({ }^{1} \mathrm{D}\right)$}

Since the preparation of these data sheets, there has appeared a preliminary note (a) reporting the following values of the rate constants for the quenching (or reaction) of $\mathrm{O}\left({ }^{1} D\right)$ at $300 \mathrm{~K}$ in units of $10^{-10} \mathrm{~cm}^{3}$ molecule ${ }^{-1}$ $\mathrm{s}^{-1}: \mathrm{O}_{2}(0.7 .0) ; \mathrm{N}_{2}(0.69) ; \mathrm{CO}(0.73) ; \mathrm{CO}_{2}(2.1) ; \mathrm{H}_{2} \mathrm{O}(3.0)$; and $\mathrm{O}_{3}$ (2.7). Each is an absolute value determined by the technique of time-resolved atomic absorption spectroscopy in the vacuum ultraviolet (b).

Although these data are not included in the data sheets, the preferred values given take them into account. These preferred values are Cvetanovic's revisions of his earlier evaluated values in (c).

(a) R. F. Heidner and D. Husain, Nature Phys. Science 241, 10 (1973):

(b) R. F. Heidner, D. Husain and J. R. Wiesenfeld, Chem. Phys. Lett. 16, 530 (1972).

(c) R. J. Cvetanovic, The Reaction of $\mathrm{O}\left({ }^{1} D_{2}\right)$, in The Natural Stratosphere, E. Reiter, editor (Climatic Impact Assessment Program, Monograph 1), preliminary draft; Nov. 1972.

Section 4.19. Photolysis of $\mathrm{H}_{2} \mathrm{O}_{2}, \lambda<300 \mathrm{~nm}$

We are grateful to Professor J. Troe for the following comments on this data sheet:
(1) Data on the absorption coefficient of $\mathrm{H}_{2} \mathrm{O}_{2}$ in the wavelength range 195-290 $\mathrm{nm}$ at higher temperatures $(650$ and $1100 \mathrm{~K})$ are given in $\mathrm{H}$. Kijewski and J. Troe, Helv. Chim. Acta. 55, 205 (1972).

(2) The temperature dependence of the absorption coefficient suggest the contribution of a second channel for photolysis (in addition to reaction (1)) for $\lambda<195 \mathrm{~nm}$.

\section{Section 4.21. The Reaction between $\mathrm{NO}$ and $\mathrm{O}_{3}$}

D. H. Stedman and H. Niki (preprint, 1972) have measured a value of $1.73 \pm 0.09 \times 10^{-14} \mathrm{~cm}^{3}$ molecule $\mathrm{e}^{-1} \mathrm{~s}^{-1}$ for $k_{1}$ by photolysis of $\mathrm{NO}_{2}(<100 \mathrm{ppm})$ in air. The reaction was studied by $\mathrm{NO} / \mathrm{O}_{3}$ chemiluminescence. This is in good agreement with other measurements. Our recommendation is unchanged.

Section 4.22. The Reaction between $\mathrm{NO}_{2}$ and $\mathrm{O}_{3}$

References ( $f$ ) and $(g)$ are both unpublished. There is less scatter to the data in $(\mathrm{g})$. The results in (f) should probably be considered as preliminary data.

Section 4.25. Collisional Quenching of $\mathrm{O}_{2}\left(a^{1} \Delta g\right)$

Findlay and Snelling (private communication) have reconsidered the data in Findlay, Fortin, and Snelling, Chem. Phys. Lett. 3, 204 (1969). They now interpret their results to give the firm upper limit: $k_{1}\left(\mathrm{M}=\mathrm{N}_{2}\right) \leqslant$ $2 \times 10^{-20} \cdot \mathrm{cm}^{3}$ molecule ${ }^{-1} \mathrm{~s}^{-1}$. We agree with their new interpretation and accept this revised value. 
Appendix

Conversion Tables

Equivalent second order rate constants

\begin{tabular}{|c|c|c|c|c|c|c|c|c|}
\hline B & $\begin{array}{c}\mathrm{cm}^{3} \\
\mathrm{~mol}^{-1} \mathrm{~s}^{-1}\end{array}$ & $\begin{array}{c}\mathrm{dm}^{3} \\
\mathrm{~mol}^{-1} \mathrm{~s}^{-1}\end{array}$ & $\begin{array}{c}\mathrm{m}^{3} \\
\mathrm{~mol}^{-1} \mathrm{~s}^{-1}\end{array}$ & $\begin{array}{c}\mathrm{cm}^{3} \\
\text { molecule }\end{array}$ & $\underset{\mathrm{s}^{-1}}{(\mathrm{~mm} \mathrm{Hg})^{-1}}$ & $\begin{array}{l}\mathrm{atm}^{-1} \\
\mathrm{~s}^{-1}\end{array}$ & $\begin{array}{l}\mathrm{ppm}^{-1} \\
\min ^{-1}\end{array}$ & $\mathrm{~m}^{2} \mathrm{kN}^{-1} \mathrm{~s}^{-1}$ \\
\hline $1 \mathrm{~cm}^{3} \mathrm{~mol}^{-1} \mathrm{~s}^{-1}=$ & 1 & $10^{-3}$ & $10^{-6}$ & $\begin{array}{l}1.66 \\
\times 10^{-24}\end{array}$ & $\begin{array}{l}1.604 \\
\times 10^{-5} T^{-1}\end{array}$ & $\begin{array}{l}1.219 \\
\times 10^{-2} T^{-1}\end{array}$ & $\begin{array}{l}2.453 \\
\times 10^{-9}\end{array}$ & $\begin{array}{l}1.203 \\
\quad \times 10^{-4} T^{-1}\end{array}$ \\
\hline $1 \mathrm{dm}^{3} \mathrm{~mol}^{-1} \mathrm{~s}^{-1}=$ & $10^{3}$ & 1 & $10^{-3}$ & $\begin{array}{l}1.66 \\
\times 10^{-21}\end{array}$ & $\mid \begin{array}{l}1.604 \\
\times 10^{-2} T^{-1}\end{array}$ & $12.19 T^{-1}$ & $\begin{array}{l}2.453 \\
\quad \times 10^{-6}\end{array}$ & $\begin{array}{l}1.203 \\
\quad \times 10^{-1} T^{-1}\end{array}$ \\
\hline $1 \mathrm{~m}^{3} \mathrm{~mol}^{-1} \mathrm{~s}^{-1}=$ & $10^{6}$ & $10^{3}$ & 1 & $\frac{1.66}{\times 10^{-18}}$ & $16.04 T^{-1}$ & $\begin{array}{l}1.219 \\
\times 10^{4} T^{-1}\end{array}$ & $\begin{array}{l}2.453 \\
\times 10^{-3}\end{array}$ & $120.3 T^{-1}$ \\
\hline $1 \mathrm{~cm}^{3}$ molècule ${ }^{-1} \mathrm{~s}^{-1}=$ & $\begin{array}{l}6.023 \\
\times 10^{23}\end{array}$ & $\begin{array}{l}6.023 \\
\times 10^{20}\end{array}$ & $\begin{array}{l}6: 023 \\
\times 10^{17}\end{array}$ & 1 & $\begin{array}{l}9.658 \\
\times 10^{18} T^{-1}\end{array}$ & $\begin{array}{l}7.34 \\
\quad \times 10^{21} T^{-1}\end{array}$ & $\begin{array}{l}1.478 \\
\times 10^{15}\end{array}$ & $\begin{array}{l}7.244 \\
\quad \times 10^{19} T^{-1}\end{array}$ \\
\hline $1(\mathrm{~mm} \mathrm{Hg})^{-1} \mathrm{~s}^{-1}=$ & $\begin{array}{l}6.236 \\
\times 10^{4} T\end{array}$ & $62.36 \mathrm{~T}$ & $\begin{array}{l}6.236 \\
\times 10^{-2} T\end{array}$ & $\begin{array}{l}1.035 \\
\times 10^{-19} \mathrm{~T}\end{array}$ & 1. & 760 & $\frac{4.56}{\times 10^{-2}}$ & 7.500 \\
\hline $1 \mathrm{~atm}^{-1} \mathrm{~s}^{-1}$ & $82.06 \mathrm{~T}$ & $\begin{array}{l}8.206 \\
\times 10^{-2} T\end{array}$ & $\begin{array}{l}8.206 \\
\quad \times 10^{-5} \mathrm{~T}\end{array}$ & $\begin{array}{l}1.362 \\
\times 10^{-22} T\end{array}$ & $\begin{array}{l}1,316 \\
\times 10^{-3}\end{array}$ & 1 & $6 \times 10^{-5}$ & $\begin{array}{l}9.869 \\
\times 10^{-3}\end{array}$ \\
\hline $\begin{array}{l}1 \mathrm{ppm}^{-1} \min ^{-1}= \\
\text { at } 298 \mathrm{~K}, 1 \mathrm{~atm} \\
\text { total pressure }\end{array}$ & $\begin{array}{r}4.077 \\
\times 10^{8} \\
\end{array}$ & $\begin{array}{l}4.077 \\
\times 10^{5}\end{array}$ & 407.7 & $\begin{array}{l}6.76 \\
\times 10^{-16} \\
\end{array}$ & 21.93 & $\begin{array}{l}1.667 \\
\times 10^{4}\end{array}$ & 1 & 164.5 \\
\hline $\mathrm{I} \mathrm{m}^{2} \mathrm{kN}^{-1} \mathrm{~s}^{-1}=$ & $8314 T$ & $8.314 T$ & $\begin{array}{l}8.314 \\
\times 10^{-3} T\end{array}$ & $\stackrel{1.38}{\times 10^{-20} T}$ & 0.1333 & 101.325 & $\begin{array}{l}6.079 \\
\times 10^{-3}\end{array}$ & 1 \\
\hline
\end{tabular}

To convert a rate constant from one set of units $A$ to a new set $B$ find the conversion factor for the row $A$ under column $B$ and multiply the old value by it, e.g. to convert $\mathrm{cm}^{3}$ molecule $\mathrm{e}^{-1} \mathrm{~s}^{-1}$ to $\mathrm{m}^{3} \mathrm{~mol}^{-1} \mathrm{~s}^{-1}$ multiply by $6.023 \times 10^{17}$.

-Table adapted from High Temperature Reaction Rate Data No. 5, The University, Leeds (1970).

Equivalent third order rate constants

\begin{tabular}{|c|c|c|c|c|c|c|c|c|}
\hline $\mathrm{A}$ & $\begin{array}{c}\mathrm{cm}^{6} \\
\mathrm{~mol}^{-2} \mathrm{~s}^{-1}\end{array}$ & $\begin{array}{c}\mathrm{dm}^{6} \\
\mathrm{~mol}^{-2} \mathrm{~s}^{-1}\end{array}$ & $\begin{array}{c}\mathrm{m}^{6} \\
\mathrm{~mol}^{-2} \mathrm{~s}^{-1}\end{array}$ & $\stackrel{\mathrm{cm}^{6}}{\text { molecule }^{-2} \mathrm{~s}^{-1}}$ & $\underset{\mathrm{s}^{-1}}{(\mathrm{~mm} \mathrm{Hg})^{-2}}$ & $\begin{array}{l}\mathrm{atm}^{-2} \\
\mathrm{~s}^{-1}\end{array}$ & $\begin{array}{l}\mathrm{ppm}^{-2} \\
\min ^{-1}\end{array}$ & $\mathrm{~m}^{4} \mathrm{kN}^{-2} \mathrm{~s}^{-1}$ \\
\hline $1 \mathrm{~cm}^{6} \mathrm{~mol}^{-2} \mathrm{~s}^{-1}=$ & 1 & $10^{-6}$ & $10^{-12}$ & $\begin{array}{c}2.76 \times 10^{-48} \\
\cdots\end{array}$ & $\begin{array}{l}2.57 \\
\times 10^{-10} T^{-2}\end{array}$ & $\begin{array}{l}1.48 \\
\times 10^{-4} T^{-2}\end{array}$ & $\begin{array}{l}1.003 \\
\times 10^{-19}\end{array}$ & $\begin{array}{l}1.447 \\
\quad \times 10^{-8} T^{-2}\end{array}$ \\
\hline $1 \mathrm{dm}^{6} \cdot \mathrm{mol}^{-2} \mathrm{~s}^{-1}=$ & $10^{6}$ & 1 & $10^{-6}$ & $2.76 \times 10^{-12}$ & $\begin{array}{l}2.57 \\
\quad \times 10^{-4} T^{-2}\end{array}$ & $148 T^{-2}$ & $\begin{array}{l}1.003 \\
\times 10^{-13}\end{array}$ & $\begin{array}{l}1.447 \\
\quad \times 10^{-2} T^{-2}\end{array}$ \\
\hline $1 \mathrm{~m}^{6} \mathrm{~mol}^{-2} \mathrm{~s}^{-1}=$ & $10^{12}$ & $10^{6}$ & 1 & $2.76 \times 10^{-36}$ & $257 T^{-2}$ & $\begin{array}{l}1.48 \\
\times 10^{8} T^{-2}\end{array}$ & $\begin{array}{l}1.003 \\
\times 10^{-7}\end{array}$ & $\begin{array}{l}1.447 \\
\quad \times 10^{4} T^{-2}\end{array}$ \\
\hline $1 \mathrm{~cm}^{6}$ molecule $\mathrm{e}^{-2} \mathrm{~s}^{-1}=$ & $\begin{array}{l}3.628 \\
\times 10^{47}\end{array}$ & $\begin{array}{l}3.628 \\
\times 10^{41}\end{array}$ & $\begin{array}{l}3.628 \\
\times 10^{35}\end{array}$ & 1 & $\begin{array}{l}9.328 \\
\quad \times 10^{37} T^{-2}\end{array}$ & $\begin{array}{l}5.388 \\
\times 10^{43} T^{-2}\end{array}$ & $\begin{array}{l}3.64 \\
\times 10^{28}\end{array}$ & $\begin{array}{l}5.248 \\
\quad \times 10^{39} T^{-2}\end{array}$ \\
\hline $1\left(\mathrm{~mm} \mathrm{Hg}^{-2} \mathrm{~s}^{-1}=\right.$ & $\begin{array}{l}3.89 \\
\quad \times 10^{9} T^{2}\end{array}$ & $\begin{array}{l}3.89 \\
\quad \times 10^{3} T^{2}\end{array}$ & $\begin{array}{l}3.89 \\
\quad \times 10^{-3} T^{2}\end{array}$ & $1.07 \times 10^{-38} \mathrm{~T}^{2}$ & 1 & $\begin{array}{l}5.776 \\
\times 10^{5}\end{array}$ & $\begin{array}{l}3.46 \\
\times 10^{-5}\end{array}$ & 56.25 \\
\hline $1 \mathrm{~atm}^{-2} \mathrm{~s}^{-1}=$ & $\begin{array}{l}6.733 \\
\quad \times 10^{3} T^{2}\end{array}$ & $\begin{array}{l}6.733 \\
\times 10^{-3} T^{2}\end{array}$ & $\begin{array}{l}6.733 \\
\quad \times 10^{-9} T^{2}\end{array}$ & $\begin{array}{l}1.86 \\
\times 10^{-44} T^{2}\end{array}$ & $\begin{array}{l}1.73 \\
\times 10^{-6}\end{array}$ & 1 & $6 \times 10^{-11}$ & $\begin{array}{l}9.74 \\
\times 10^{-5}\end{array}$ \\
\hline $\begin{array}{c}1 \mathrm{ppm}^{-2} \min ^{-1}=\text { at } 298 \mathrm{~K} \\
1 \mathrm{~atm} \text { total pressure }\end{array}$ & $\begin{array}{l}9.97 \\
\times 10^{18}\end{array}$ & $\begin{array}{l}9.97 \\
\times 10^{12}\end{array}$ & $\begin{array}{l}9.97 \\
\times 10^{6}\end{array}$ & $\begin{array}{l}2.75 \\
\times 10^{-29}\end{array}$ & $\begin{array}{l}2.89 \\
\times 10^{4}\end{array}$ & $\begin{array}{l}1.667 \\
\times 10^{10}\end{array}$ & 1 & $\begin{array}{r}1.623 \\
\times 10^{6}\end{array}$ \\
\hline $1 \mathrm{~m}^{1} \mathrm{kN}^{-2} \mathrm{~s}^{-1}=$ & $\begin{array}{l}6.91 \\
\quad \times 10^{7} T^{2}\end{array}$ & $6.91 T^{2}$ & $\begin{array}{l}69.1 \\
\quad \times 10^{-5} T^{2}\end{array}$ & $\begin{array}{l}1.904 \\
\times 10^{-40} T^{2}\end{array}$ & 0.0178 & $\begin{array}{l}1.027 \\
\times 10^{4}\end{array}$ & $\begin{array}{l}6.16 \\
\times 10^{-7}\end{array}$ & 1. \\
\hline
\end{tabular}

See note to table for second order rate constants. 
Conversion factors for units of molecular energy

\begin{tabular}{l|l|l|l|l|l|l|l}
\hline \multirow{2}{*}{$1 \mathrm{~J} / \mathrm{mol}=$} & \multicolumn{1}{|c|}{$\mathrm{J} / \mathrm{mol}$} & \multicolumn{1}{|c|}{$\mathrm{cal} / \mathrm{mol}$} & \multicolumn{1}{c|}{$\mathrm{cm}^{3} \mathrm{~atm} / \mathrm{mol}$} & $\mathrm{kWh} / \mathrm{mol}$ & $\mathrm{Btu} / \mathrm{lb}-\mathrm{mol}$ & $\mathrm{cm}-1 / \mathrm{molecule}$ & $\mathrm{eV} / \mathrm{molecule}$ \\
\cline { 2 - 8 } & 1 & $2.390057 \times 10^{-1}$ & 9.86923 & $2.77778 \times 10^{-7}$ & 0.429923 & $8.35940 \times 10^{-2}$ & $1.036409 \times 10^{-5}$ \\
\hline $1 \mathrm{cal} / \mathrm{mol}=$ & 4.18400 & 1 & 41.2929 & $1.162222 \times 10^{-6}$ & 1.798796 & $3.49757 \times 10^{-1}$ & $4.33634 \times 10^{-5}$ \\
\hline $1 \mathrm{~cm}^{3} \mathrm{~atm} / \mathrm{mol}=$ & 0.1013250 & $2.42173 \times 10^{-2}$ & 1 & $2.81458 \times 10^{-8}$ & $4.35619 \times 10^{-2}$ & $8.47016 \times 10^{-3}$ & $1.050141 \times 10^{-6}$ \\
\hline $1 \mathrm{kWh} / \mathrm{mol}=$ & $\underline{3,600,000}$ & 860,421 & $3.55292 \times 10^{7}$ & 1 & $1,547,721$ & 300,938 & 37.3107 \\
\hline $1 \mathrm{Btu} / \mathrm{lb}-\mathrm{mol}=$ & 2.32600 & $5.55927 \times 10^{-1}$ & 22.9558 & $6.46111 \times 10^{-7}$ & 1 & $1.944396 \times 10^{-1}$ & $2.41069 \times 10^{-5}$ \\
\hline $1 \mathrm{~cm}-1 / \mathrm{molecule}=$ & 11.96258 & 2.85912 & 118.0614 & $3.32294 \times 10^{-6}$ & 5.14299 & 1 & $1.239812 \times 10^{-4}$ \\
\hline $1 \mathrm{eV} / \mathrm{molecule}=$ & 96487.0 & 23060.9 & 952,252 & $2.68019 \times 10^{-2}$ & 41482.0 & 8065.73 \\
\hline
\end{tabular}

The underlined numbers represent the fundamental values used in deriving this table. The remaining factors were obtained by applying the relationships: $n_{i j}=n_{i k} \cdot n_{k j}, n_{i i}=n_{i k} \cdot n_{k i}=1$.

Gas constant. $R=8.3143 \pm 0.0012 \mathrm{~J} / \mathrm{K} \mathrm{mol}=1.98717 \mathrm{cal} / \mathrm{K} \mathrm{mol}=82.056 \mathrm{~cm}^{3} \mathrm{~atm} / \mathrm{K} \mathrm{mol}=0.69502 \mathrm{~cm}^{-1} / \mathrm{K} \mathrm{molecule}=8.6170 \times 10^{-5} \mathrm{ev} / \mathrm{K}$ molecule. (From NBS Technical Note 270-3.)

\section{Units of Optical Absorption Coefficients}

The molar (linear) absorption coefficient $\epsilon$ is defined by the Lambert-Beer equation: $\epsilon=(1 / l c) \log _{10}\left(I_{0} / I_{t}\right)$ where $I_{0}$ and $I_{t}$ are incident and transmitted intensity, $l$ is the path length, and $c$ is the concentration.* The units for $\epsilon$ are (concentration ${ }^{-1}$ length $^{-1}$ ).

A variety of equivalent forms of this equation have been used to define reported values of $\epsilon$. Both logarithmic bases $e$ and 10 have been used. Length has invariably been expressed in $\mathrm{cm}$. Concentration has usually been expressed in (mol/liter). Often a pressure unit has been used instead of a concentration unit, in which case the temperature to which the value of the pressure is referred must be specified. When pressure units are used the absorption coefficient is usually denoted by

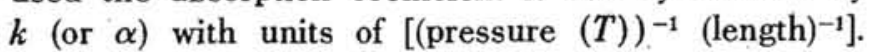

- Commission on Symbols, Terminology, and Units, I.U.P.A.C., M. L. McGlashan, chairman, Pure and Applied Chemistry, 21, 1 (1970).
When the pressure unit used is (1 atmosphere at 273 $\mathrm{K}$ ), the value of $k$ is expressed in any of the numerically equivalent forms: [(atm at $\left.273 \mathrm{~K})^{-1} \mathrm{~cm}^{-1}\right]$; [NTP $)^{-1}$ $\mathrm{cm}^{-1}$; or $\mathrm{cm}^{-1}$. This last form is equivalent to converting the measured value of $l$ at $T$ and $P$ to its corresponding value $l_{0}$ at the reference state $T_{0}=273 \mathrm{~K}$ and $P_{0}=1$ atm $\left.\left(i_{0}=l \times\left(P / P_{0}\right) \times T_{0} / T\right)\right)$ and using the eqn: $k=(1 /$ $\left.l_{0}\right) \log \left(I_{0} / I_{t}\right)$.

Alternatively the molecular concentration, $n$, expressed in $\left(\right.$ molecules $/ \mathrm{cm}^{3}$ ) may be used. Then the molecular "cross-section", $\sigma$, is defined as $\sigma=(1 / n l)$ $\log _{e}\left(I_{0} / I_{t}\right)$.

Because of the diversity of units, when using reported values in numerical calculations one must always determine what defining equation was used. When reporting absorption coefficients it is recommended that the units be given explicitly and that the defining equation appear in table and figure captions.

A table of conversion factors is shown below. 
Conversion factors for units of optical absorption coefficients

\begin{tabular}{|c|c|c|c|c|}
\hline $\mathrm{A}^{\mathrm{B}}$ & $\begin{array}{c}(\text { Cross section } \sigma) \\
\mathrm{cm}^{2} \text { molecule }{ }^{-1} \text { base } e\end{array}$ & $\begin{array}{c}\text { (atm at } 273)^{-1} \mathrm{~cm}^{-1} \\
\text { base } e\end{array}$ & $\begin{array}{c}\mathrm{dm}^{3} \mathrm{~mol}^{-1} \mathrm{~cm}^{-1} \\
\text { base } 10\end{array}$ & $\mathrm{~cm}^{2} \mathrm{~mol}^{-1}$ base 10 \\
\hline 1 (atm at 298$)^{-1} \mathrm{~cm}^{-1}$ base $e=$ & $4.06 \times 10^{-20}$ & 1.09 & 10.6 & $1.06 \times 10^{4}$ \\
\hline 1 (atm at 298$)^{-1} \mathrm{~cm}^{-1}$ base $10=$ & $9.35 \times 10^{-20}$ & $2.51^{\circ}$ & 24.4 & $2.44 \times 10^{4}$ \\
\hline $1(\mathrm{~mm} \mathrm{Hg} \text { at } 298)^{-1} \mathrm{~cm}^{-1}$ base $10=$ & $7.11 \times 10^{-17}$ & $1.91 \times 10^{3}$ & $1.86 \times 10^{4}$ & $1.86 \times 10^{7}$ \\
\hline $1(\text { atm at } 273)^{-1} \mathrm{~cm}^{-1}$ base $e=$ & $3.72 \times 10^{-20}$ & 1 & 9.73 & $9.73 \times 10^{3}$ \\
\hline 1 (atm at 273$)^{-1} \mathrm{~cm}^{-1}$ base $10=$ & $8.57 \times 10^{-20}$ & 2.303 & 22.4 & $2.24 \times 10^{4}$ \\
\hline $1 \mathrm{dm}^{3} \mathrm{~mol}^{-1} \mathrm{~cm}^{-1}$ base $10=$ & $3.82 \times 10^{-21}$ & 0.103 & $1 \ldots$ & $10^{3}$ \\
\hline $1 \mathrm{~cm}^{2} \mathrm{~mol}^{-1}$ base $10=$ & $3.82 \times 10^{-24}$ & $1.03 \times 10^{-4}$ & $10^{-3}$ & 1 \\
\hline $1 \mathrm{~cm}^{2}$ molecule $\mathrm{e}^{-1}$ base $e=$ & 1 & $2.69 \times 10^{19}$ & $2.62 \times 10^{20}$ & $2.62 \times 10^{23}$ \\
\hline
\end{tabular}

To convert an absorption coefficient from one set of units A to a new set B, multiply by the value tabulated for row A under column B, e.g.

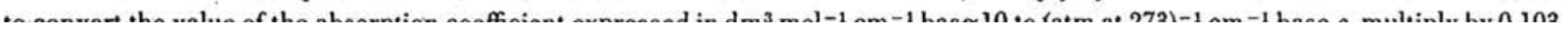

